\title{
第V群 発声機構（III）
}

\author{
46. 生体内電気刺激装置 \\ 一反回神経への応用に関する基礎的研究一
鹿児島大学耳鼻咽喉科 大山 勝, 勝田 兼司, 大野 聖
昇卓夫, 原口 申一
伊勢慶応病院ME科 溝井 一敏

生体に打ける神経筋単位の中には, 電気生理学的に低 頻度の刺激に対して反応をしめす群と, 高頻度のそれに 良く反応する 2 つの異なった群の存在することが知られ ている.

喉頭においても，このような電気生理学的反応の違い が声門閉鎖筋と開大筋の間で観察されている.

今回は, 反回神経あるいは喉頭筋を電気刺激し, 声門 運動を人為的に制御する生体内埋め込み型の刺激装置を 試作したので，その装置の概要を紹介するとともに，動 物実験成績の一部を映画に，またその際の音声の変化を 収録して，それぞれ解析した成績を述べた。

電気刺激装置としては, インダクション方式と小型ゼ ネレータ方式の 2 種類の器械を試作して行った.

インダクション方式の刺激装置は，一次コイルをドラ イブする外部刺激装置と生体内に埋没する二次コイル装 置からなり, 磁気誘導により両コイル間の距離が $2 \mathrm{~cm}$ 内 外の位置から, ワイヤレスで電気刺激を与えることが可 能である. この場合, 生体内にはコイルのみ埋没するの で，小型化でき，故障が少なく電池交換を必要とせず, そのうえ, 刺激条件を自由に変化しらる利点がある。一 方外部刺激装置を必要とするため移動に不便で, また, 大出力が期待しえないデメリットがある.

小型ゼネレータ方式刺激装置は, $1.5 \mathrm{~V}$ 銀電池を電源 に用い，小型化および電池消耗を最少にするため, ブロ ッキング発振回路で生ずるパルスを直接生体電気刺激と して利用し, かつ, マグネットスイッチの付いた埋め込 み発振器とマグネットからなっている. したがって, こ の場合, 外部刺激装置が不要であり, 移動が自由で, 出 力も大きくできる反面, 埋め込み装置がいくぶん大き く, 電池交換の必要があり, 刺激条件の固定化という難 点がある. これらの装置の中, 生体内に埋め込む部分 は, 発振器およびリード線をすべてシリコンゴムでコー ティングし，電極部分のみを露出せしめた．また，小型
ゼネレータ方式の発振器は, 生体内に埋没前に目的に応 じた刺激頻度 (10〜 $60 \mathrm{~Hz}$ まで可変)を，あらかじめ設 定する必要がある.

以上のごとく, 両生体内電気刺激装置には，それぞれ 長所, 短所がみられるので, これらを勘案した結果，ま た動物実験成績からもインダクション方式装置は, 主と して神経刺激に，一方，小型ゼネレータ方式のそれは， 筋刺激に利用するのが最も合目的的であると考えられ る.

筋刺激実験は，イヌを用いて，ネンブタール静脈麻酔 下に頸部正中切開を加え, 前頸筋群を左右に圧排した 後, (1)前筋, (2)甲状軟骨を一部切除後に閉鎖筋群をそれ ぞれ別個に施行した．その結果，一側前筋刺激により声 帯の伸展，閉鎖筋刺激により声帯の内転像をみるなど刺 激の有効性が立証された. 一方, 反回神経 刺 激 実 験で は, 低刺激頻度 $(10 \sim 20 \mathrm{~Hz})$ では, 同側声帯の開大を, また刺激頻度 25～40Hz では閉鎖を，さらに高頻度にな ると声門は強く絞扼し, あたかも他側声帯への刺激の影 響を思わしめる像が観察された。一をた，浅麻酔下に live voice 発声中に本装置による電気刺激を試み，その際生 ずる刺激頻度の違い $(25 \mathrm{~Hz}, 50 \mathrm{~Hz})$ による音声の変化 を記録，分析した。 その結果， live voice 中にみられた 比較的規則正しい三角波形（基本周波数約 $600 \mathrm{~Hz}$ ）は, 電気刺激により低調, 吹鳴様で, 雑音成分の著明な混入 がみられた。

インダクション方式の刺激装置を 8 カ月間, 埋め込ん だ実験動物について，装置による局所の組織反応を検索 したが，肉眼的に表在性一部に瘢痕様組織変化を証明し たが，装置周囲組織に特に異常反応はみられなかった。

また，電極接着部の神経について，光顕的，ならびに 電顕的に観察したが, 神経外鞘の多少の肥厚をみるほか, 軸索, 髄鞘などには異常はなく, 細胞浸潤像は全く認め られなかった. 


\title{
47. 発声時の声帯運動に関する X 線学的研究
}

\author{
九州大学耳鼻咽喉科 広戸幾一郎, 藤沢 成人
}

従来の研究方法は断層撮影か高王撮影によっており, その成績はほぼ同様である，声帯の長さは男で約 $24 \mathrm{~mm}$ 女で18mmであり, 胸声区の低音発声では吸息時より短 くなり，漸次声が高くなるにつれて長くなってゆく．声 帯の厚みは声が高くなるにつれて薄くなる. 喉頭室の広 さは低音から中音にかけて扗大するが，高音では狭くな る傾向がある，喉頭蓋と声帯との角度は声が高くなるほ ど鋭角となる．これらの成績は私どもの造影撮影法にお いても同様であった.

発声時の声帯の位置の計測は, 鎖骨, 頸椎, 上顎洞の 影像を基準として計測されており，たとえばFrommholdは, 熟練したオペラ歌手では声が高くなるにつれて 声帯の位置は低くなるが，未熟者では高くなると述べて いる. 発声時には喉頭は挙上するから, 彼のいう声帯の 位置は喉頭内部における絶対的位置ではなく, 喉頭自体 の運動も加味された相対的位置である. 喉頭軟骨はX線 に写らないから声帯の絶対的位置変化を読むことは不可 能であった.

喉頭造影法では気管も造影される. 発声時には気管も 喉頭とともに挙上されるが，その形状は変化しない。発 声時と吸息時の気管の影像を重ね合わせると喉頭内の諸 変化を計測することが可能であり，これを喉頭造影像重 ね合わせ法と呼ぶ. その成績は次のごとくである.

声が高くなるにつれて声帯の相対的位置は高くなる
が，絶対的位置は低くなる，会話声では男で約 $4 \mathrm{~mm}$, 女で約 $3 \mathrm{~mm}$ 下降する．声が高くなる汇ど喉頭自体の上 昇度も声帯の絶対的下降度もともに大となる. 声区変換 部では声の高さは同じでも，胸声の方が喉頭の上昇度も 声帯の喉頭内に打ける絶対的下降度もともに頭声の場合 より大である. したがって Frommhold の熟練した歌手 では，声の高低に関係なく喉頭そのものは同じ位置に保 持されているのであろうと推察される.

質 問：東大・新美成二 異なる pitch での声带前 後方向の傾斜について所見があったらご教示願いたい.

応 答 : 九大・広戸幾一郎 声帯の前部は前連合で甲 状軟骨に付着しているから位置の移動はない. 発声時に 下降するのは披裂軟骨声帯突起である。ちなみに，高 圧, 造影の正面像は断層の声帯突起部のセクションとほ ぼ同じである。

追 加：自治医大・切替一郎 熟練した歌手の発声時 の喉頭の高さについて, 故颯田琴次先生はバスの名手シ ヤリアピンを例にひいて, 声の高さによって喉頭の高さ が変わらず, また外頸筋の緊張や血管努張など全くみら れないと教えられた. 先生は phonetische Nullpunkt の意義についても強調された. また歌手ではないが，あ る有名な落語家が声を高くすると喉頭が下がってくる例 があり，この人では意識的にも喉頭を下げることができ た.

\section{8. 喉頭マニュアルテストの診断的意義}

発声障害の外科的治療適応の決定には，種々のテスト が用いられるが, 術後の音声を予測することは, 容易で はない.われわれの用いている術前の喉頭マニュアルテ ストの音声と甲状軟骨形成術後音声を比較検討 した 結 果，マニュアルテストにより術後音声が，かなり予測で さることがわかったので報告する.

マニュアルテストは, 普通 3 つの方法を用いている. マニュアルテストI 型, 声帯腫脹, 腫瘍を認めず, 発声
京都大学耳鼻咽喉科 大川 正直, 田辺 正博 京都大学形成外科 張田裕, 一色 信彦

時声門閉鎖不全を認めるものが適応として考号られる。 具体的には片側反回神経麻疸, 声帯萎縮などで, 手 技 は，右手で両甲状軟骨翼をはさむようにつか及，翼を両 側より压迫し声の変化をみる. 圧迫部位, 程度により, 音声はデリケートに変化する. 何回も圧迫部位を変えて 試みる．音声改善が得られるなら甲状軟骨形成術 I 型, または披裂軟骨内転術の適応となる。

マニュアルテストII型, 声帯が過度に緊張した場合, 
具体的には, 変声障害, 過㛑張性省声障害など. 手技

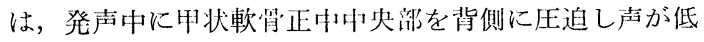
くなるかどうかを文る。声が低くなるようなら甲状軟骨 形成術III型の適応となる.

声が低すぎの場合，具体的には，脳血管障害で声帯が 過度に弛緩し嗄声をさたしている場合. 女性での蛋白同 化ホルモンまたは男性ホルモンによる男性化音声などで は, 声は低く, 粗䊁性嗄声で弛緩が高度な場 合には声 は, 八タハ夕と無力性ともなる. このような場合, マニ ュアルテストIII型, すなわち, 左手で甲状軟骨上縁をお さえ，右示指を輪状軟骨下縁に接し上方に押し上げ輪状 甲状軟骨距離を短縮する．中央をたは左右どちらかに偏 して行うこともある，これで音声が改善すれば，甲状軟 骨形成術IV型の適応となる。

以上のような音声障害に対してこれらの方法により術 前に術後の音声を推測することがかなりの程度可能とな る. 患者にも「手術すれば少なくともこのぐらいの声に はなりますよ」と説明でき, 患者の不安を緩和するのに 役立つ。

質 問 : 東大分院・牛岛達次郎 マニュアルテスト時 と術後とでは音声サンプルの pitch が違っているが，そ の点はどのように考光ておられるか.

応 答: 京大・大川正直 術後 12 日目であり, 声带腫 脹があるためにやや低音になっているが，術後の経過と
ともに徐々に軽快し, 術後約 1 カ月で, マニュアルテス トで予測された音声となっている。

質 問：名保衛大・岩田重信 本マニュアルテストの 適応は，反回神経麻痺が主体となると思らか。 その他， 応用できる疾患については，いかがか.

応答 : 京大・大川正直 マニュアルテストは反回神 経麻痺以外にも使用している。I 型 (甲状軟骨兩翼圧 迫）は反回神経麻痺，II型（甲状軟骨正中中央圧迫） は, 声帯の過緊張, III型 (甲状軟骨と輪状軟骨の近接) は, 脳血管障害による麻症, 女性の男性化ホルモン使用 による嗄声に，用いている。

質 問 : 三井記念病院・岩村 忍 片側反回神経麻㽻 の症例のなかには, 単に麻瘏声帯の正中移動術では改善 しないものがある，喉頭全体が健側より麻疩側に遊泳す るがごときで, 喉頭内部の操作だけでは音声改善を得ら れないと考えられる訳で，このような症例で，手指で甲 状軟骨を固定すれば発声時の喉頭全体の遊泳は消失する ので，音声改善が得られてこょう.手指で甲状軟骨を外 側から圧抵する lateral compression はこの種の喉頭固 定の意味づけとなりらるか.

梞 答 : 京大・田辺正博 声門軸の偏位の矯正による 音声の改善ではなく，声門間隙がなくなるための改善と 考える. 声門間隙があまりなく軸の偏位のみの症例の経 験はない.

\section{9. 片側反回神経麻痺における健側声帯の代償性過内転機構}

三井記念病院耳鼻咽喉科 岩村 忍, 谷島貴志子

片側反回神経麻疩の治療は，一般的には発声訓練をも ってはじめられる．両手を何かにあて上半身を前方に押 し出す瞬間に「エー」とか「アー」とか力強い発声を同 時にやらせる pushing exercise がよいとされる. 生理 学的解釈をすれば, 健側声帯の代償性過内転を期すると いらことになろら．声帯の内転に関与する喉頭笳は, 輪 状甲状筇 (前筋), 甲状披裂筋 (声帯筋), 外側輪状披裂 筋 (側筋) および声門後方閉鎖に関与する横披裂筋（横 筋）とされている.声帯膜様部の内転運動を作動させる 筋群は前者の三筋である. 本研究でこの三筋のいずれが 声带の過内転機構の主役を演じているかを追求する.

実験方法：正常喉頭をもつ成犬 10 匹（10～22kg）を nembutal 麻酔下に, 右反回神経を頸部気管第 $2 \sim 3$ 輪の高さにて切断し, 切断端の中枢側を橎転結紮し再生 を阻止した. 術直後, 右声帯の不動を喉頭值達鏡下にて
確認した. 術後 $2 \sim 8$ カ月に再び nembutal 麻酔を行 い，右麻痺声帯が副正中位または中間位に固定している ことを喉頭直達鏡にて確認した。 また筋電図にて術側内 喉頭笳からの発射なさことを確認した，ついで, 頸部手 術により, (1)右反回神経の再生なきことを確認. (2)左反 回神経, 両側上喉頭神経外枝および両側下咽頭収縮筋の 露出. (3)舌骨甲状軟骨間部を外部から正中切割し喉頭蓋 を前方に率引し, 声帯面の值視を可能とした. (4)輪状甲 状軟骨間の中点より内腔に向かい長針を貫通させ輪状軟 骨後端に刺入した. 刺入点は直達鏡下に両側披裂軟骨の 中点と思われる部位とし，この長針を健側声帯過内転の 指標とした.

浅麻酔下にて自然発声を開始させ, 声帯の内転度を35 mmフイルムに撮影記録した.

結 果: 成犬 10 例中, 中間位固定が 8 例, 残りの 2 例 
が副正中位固定を示した。 また発声時に軽度ながら健側 に向かって喉頭の twist を認めた. 健側声帯の過内転 は 5 例, 残りの 5 例は正中側をこえなかった.

1）全例に和いて麻疾側の下咽頭収縮筋切断は健側声 帯の内転度に何の影響も与えなかった.

2）全例に打いて両側下咽頭収縮筋切断は健側声帯の 内転度に変化を及ぼさなかった.

3）両側下咽頭収縮筋切断ののち麻痺側上喉頭神経外 枝を切断した8例では, 喉頭全体の麻痺側への twist が発 声時に増強して生じ, 両声帯の伸展が減弱し, 声のピッ チが低下したが健側声帯の内転度には著変はなかった.

4）上記 8 例に，さらに健側上喉頭神経外枝を切断 し，したがって両側前筋機能を廃絶したところ，上述の 所見が著明になっただけで健側声帯の内転度にはやはり 著変はなかった。

5）両側下咽頭収縮筋および両側前筋機能停止のの ち，さらに健側側筋を支配せし神経枝を選択切断した 2 例においては両側ともに健側声帯の内転度は著減した。 嗄声度は上昇した.

6）側筋の影響が大なることを確認するために，他の 2 例に扣いて, 両側下咽頭収縮筋切断ののち, 両側前筋 を温存したまま，健側側筋のみ機能停止させた。 やはり 健側声帯の内転度は激減した. こののち両側前筋機能を 廃絶したが，健側声帯の内転度には著変は生:じなかっ た.

7）両側下咽頭収縮笳および両側前筋の機能廃絶のの ちに，健側声帯筋を支配する神経枝の選択切断を 3 例に 行った. 健側声帯の内転度には変化が生ぜず, 過内転が 残存した.

結 語 : 脱落実験の結果から，代償性過内転機構の主 役は外側輪状披裂筋 (側筋) と推察されたた。片側反回神経 麻痺における vocal rehabilitation には単なる発声訓練 よりも，力をこめる pushing exercise が望ましいこと となる。

質 問 : 度大・村上 泰 (1)切断側の声帯位は全例中 間位か. (2)overcross した群とそうでない群があるの はなぜか. (3)する群としない群の間で EMG上の差があ ったか。

応 答: 三井記念病院・岩村 忍 (1)麻痺声帯位は10
例中 8 例が中間位， 2 例が副正中位を示した. (2)overcrossing を示したもの，示さなかったものの間でどんな 差が内喉頭筋にあるのかは，筋電図学的に調查した限り では, 差がないように思う. vocal rehabilitation とし て外側輪状披裂筋を full contraction させるや否かが, 絬局, overcrossing の有無に通ずるのではないかと考光 る.

質 問：長崎大・佐藤意生 横筋の作用についてはど のように考えるか.

応答 : 三井記念病院・岩村 忍 (1)成犬では人間喉 頭と異なり，横筋は片側支配であるので，麻痺側横筋も 一緒に機能脱落してくる. したがって, overcrossing mechanism に麻瘒側横筋は関与しないと考える. (2)下 咽頭収縮筋, 輪状甲状笳および甲状披裂筋の脱落は, 健 側声帯の内転度には著しい影響をあたえない.内転度に 大きく貢献する筋は外側輪状披裂筋である.

質 問 : 久留米大・平野 実 喉頭筋の中で電気刺激 を加えて収縮させた場合に声帯の過内転を起こすのは側 筋だけである. したがって演者の結論は妥当である. と ころで人でも犬でも反回神経麻瘴が起こったとき, 過内 転の起こる例と起こらない例がある，これはなぜだと考 えるか.

応 答 : 三井記念病院・岩村 忍 健側声帯の overcross の有無は, 健側の外側輪状披裂筋の full contraction と関連があると考えている.つまり，筋全体のful contraction があれば overcross が起こるであろう。人 の場合, 普通会話程度の発声様式扣よび頻度では健側内 喉頭筋一ことに外側輪状披裂筋の full contraction は 期待できない. pushing exercise などの作業に並列し て発声訓練を施行すれば, 筋の full contractionをもた らすことができ，したがって健側声帯の overcrossを期 待することができると考える.

実験動物（成犬）では overcross を示した 5 例と overcross なき 5 例の間では, 筋電図学的に顥著な差を認 めていないが，overcross のあった例の外側輪状披裂筋 のほうが活動電位の発射が旺盛のようにも思えた. 筋電 計に加算装置をつけて計測すると，両グループの間に差 を認めることができるかも知れない。 


\section{0. 反回神経麻痺に対する機能再建手術}

京都府立医科大学耳鼻咽喉科 竹之内 智, 佐藤 文彦, 矢野原邦生, 水越 治

反回神経麻痺による呼吸困難, 嗄声, 失声抽よび䛊䁵 症例に対し機能再建術を行いほぼ満足する結果を得たの で報告する.

症例 1 は45歳女子, 数年前より労働時にまた最近は夜 間横臥時に呼吸困難発作あり，気管切開した両側後筋麻 痺例で両声帯はほとんど正中位付近にあり, 筋電図上声 帯筋，後筋ともに筋放電を認めたが閉鎖筋優位との判断 から右側閉鎖筋分布神経を切断し，後筋による声带外転 運動を期待したが良好な結果を得ないために，声帯外転 術を行い呼吸困難は緩解した。 またさきに切断した閉鎖 筋分布神経のかわりに上喉頭神経外枝を有茥にした前筋 升を声帯筋，側筋へ移植し声帯筋萎縮を防止した。術後 軽い音声の変化があったが労働時の呼吸困難もなく漸次 声帯の萎縮も回復し音声も良好となった.

症例 2 は42歳女子で甲状腺腫瘍にて左側反回神経との 痛着を剝離して左葉全摘出術を行ったために左声帯の外 転麻痺を惹起した症例で，ただちに左舌下神経係蹄を有 茥にした胸骨舌骨筋弁を左後筋へ移植縫合した。術後軽 い音声の変化がありまた左側声帯の外転運動が見られな かったが術後約 6 週後には正常な外転運動を認めるまで 回復した.

症例 3 は69歳男子で胸部食道癌のために食道抜去後胃 挙上による食道再建術後約 2 年経過して嗄声が発現し, 水分を誤㫶し, 嗄声増強し, 㫶下性肺炎を起こして再入 院したが，左側声帯は萎縮し，中間位付近に固定し，右 側声帯の代償作用にかかわらず発声時，㺞下時の声門閉 鎖状態の悪いことを示した.

本症例に対し声帯の萎縮を改善し，声帯の内転運動を も期待できる上喉頭科定外枝を有茎にした前筇弁を麻痺 側声帯筋，側筋へ移植縫合する有茥神経筋弁法を行った が，本症例のように噁下性肺炎があるために声帯の内転 の効果を手術直後から期待する必要にせをられ，患側甲 状軟骨板上に小空を作りここよりシリコンゴムを挿入し 声帯隆起を内方へ突出させ声門間隙を狭めた. 手術直後 より患者の音声は著明に改善され, 左声帯は正中位近く

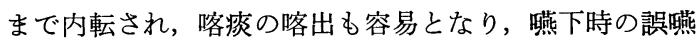
もなくなり音声も良好となり，また肺の所見も非常に改 善された.

次の症例は73歳男子で胸部食道癌手術後, 胸骨後部に 沿って胃挙上による食道再建術後通過状態も良好であっ
たが， 2 力月後に嗄声となり失声状態，流動物の誤嬹の ために㫶下性肺炎を起こした症例で，右側声帯は中間位 付近にあり声帯の萎縮強く, 発声時, 曣下時の声門閉鎖 が不十分であった.

本症例にも前筋弁を患側声帯筋，側筋へ縫合する有茥 神経筋弁法を行い,ささらに声門間隙を狭めるために, 患側 甲状軟骨板上で声帯の走行に沿った短冊状の軟骨板を切 離し，これを喉頭内へ押し込み声帯の内転を行ら一色氏 の甲状軟骨形成術を併せ行った.

この症例でも手術直後より発声しやすくなり，経過と ともに音声も改善され䛊㫶もなくなり約 2 力月後には, 内転術により膨隆を示す右側声帯が副正中位付近にあ り，これが発声時さらに内転運動を示すようになり，咳 嫩時の喀痰の排出も容易になり肺の所見も短時日に改善 した。

以上麻痺声帯に対し有茎神経筋弁法と声帯外転術また は内転術を併用して音声上良好な結果を得たので報告し た。

質 問 : 三井記念病院・岩村 忍 (1)症例 1 につい て, 後筋支配神経枝の切断後, その評価には術後 2 力月 は待って欲しかった. 次に, 声門開大の目的で手術操作 をされながら，今度は側筋の部位に前筋を弁として植え 込まれておられ，声門をわざわざ狭くされておられる点 に矛盾を覚えるがいかが. (2)症例 2 について, ansa hypoglossi を利用される場合に, maximum waiting period はどのくらいか. また， ansa hypoglossi に支 配された筋肉の収縮は, 安静呼吸時にはなく, 強制の深 吸気時にのみ認められるが，先生の human case では この点いかがであったか.

応 答 : 京都府医大・竹之内 智 声帯が外転しない 場合閉鎖筋枝を切断し，後筋の開大作用を期待したが， この場合切断後約 1 時間観察しただけである.ご指摘の ように今後例があれば 2 カ月待ちたいと思ら. 声門開大 したのにまた声帯筋へ閉鎖筋作用のある手術を行らのは 矛盾するようであるが神経を切断したのであるから，後 の発声の事を考えると神経の再支配をしたほうがよいと 思う. 症例 2 の後筋枝切断後ただちに胸骨舌骨筇弁を縫 合したが，動物実騟では 3 カ月以内ならば運動回復が確 実であるといら結論を得ている. しかし早いほどよいと 思われる. 
質 問 : 東大・沢岛政行 一側の反回神経麻痺では， 従来の mediofixation operation で目的は達せられる. 声帯の可動性そのものを回復させるこのような手術の本 当の適応は, 両側反回神経麻㽻であると思うがいかが.

応 答: 京都府医大・竹之内 智 たしかに一側麻㽻 だけでなく両側に行って声带が動けば確実である。動物 央験で両側行い，両側ともに内転外転運動が回復した例 は数例ある. 人に搔いては両側施行した例は経験してい ない.

質 問：度大・村上 こ泰このうな手術は声帯位を 変えるほどの力があるのか, 単に筋の tonus を保つか
萎縮を防ぐのが目的なのか, 深吸気や労働時の前筋は吸 気相優位であるから, 声帯位まで変えるほどの力がない と考えるほうがよいのではないかと思う。

応 答：京都府医大・竹之内 智 前筋を利用した有 茎神経筇升を麻痺声帯に移植するのは, 目的としては麻 痺声帯の内転運動の回復である. しかし現在までの臨床 例ではむしろ筋の萎縮を回復さす作用が表面に出てい る.しかし動物奏験では両側に行って声带運動の回復し ている例がほとんどである.なお一側に行った場合前筋 尙の移植例が早く内転運動を起こす.

\title{
51. 痤攣性発声障害に対する一側反回神経ブロックの経験
}

\author{
東京大学音声言語医学研究施設 廣瀬 肇, 沢島 政行, 新美 成二 \\ 三井記念病院耳鼻咽喉科 岩村 忍 \\ 東京大学耳鼻咽喉科 牛島達次郎
}

痤攣性発声障害は，圧迫性発声，声のふるえなどと表 現される特徴的な音声所見のため, 古くから注目を集め ていた．診断は主として臨床的所見に基ついて行われ， 一般に, Luchsinger"1) らの定義に従い“strained, creaking, choked vocal attack および tense, squeezed voice によって特徵づけら, 発声器官全体の極端な緊張 を伴ら発声障害”と考えられている.

本症の本態については多くの議論があるが, 従来心因 性要素が重視され，しかもきわめて難治であることが知 られている. 事奏われわれの経験でも, 精神心理学的療 法によって改善したと考えられる例はごくまれである. な打本症の発症頻度は低く, 1970年から1978年までの 9 年間に東大音声言語外来で本症と診断された症例は28例 で，これは同期間に心因性発声障害と診断された症例 80 例中の $35 \%$ 占めるが，同外来総新患数の約 $1.5 \%$ にす ぎない.

近年に至り, Dedo ${ }^{2}$ は本症の多数例について一側反回 神経を切断し満足すべき治療効果をあげたと報告してい る. 最近の彼の統計 (Dedo, 個人的通知) では1978 年夏 現在, 161例に右側反回神経切断術を施行し, 全例にみ るべき効果を执さめたが，このらち 9 例に再発をみたと いう. 彼は本症が，ウイルス感染によって反回神経中の proprioceptive components が障害されて発症するとの 仮説を唱えているが確証はない。

われわれは彼の方式を検討し，さらによい方式を開発
しようと考案中であるが，今回は予備段階として本症症 例に反回神経ブロックを試みた結果について報告した。

本症に対する神経ブロックの経験 : 1977 年以内 5 例 に，0.5〜 1\%キシロカインを用い一側反回神経ブロッ クを陚みた. 注射部位は Dedoにならい, 主として右 輪状甲状関節の高さとしたが，輪状軟骨下縁より約 $1 \mathrm{~cm}$ 下方で気管側壁に沿ってブロックを試みた例もある. 平 均 $5 \sim 6 \mathrm{~m} l$ の注射を行ったが，全例とも注射後約 10 分 以内に，自他覚的に声の変化をきたし，疘攣性の特徵は 消失した．間接喉頭鏡検査では被注射側声帯は副正中位 ないし中間位に固定され，この状態は約15分程度持続し た.この時の患者の声の性質は主として声帯位に依存す ると考えられ，著しい気息性を呈した例もある。患者自 身の評価としては，全例とも楽に発声できることを自覚 したが，症例によっては同時に声のかすれ，声が “抜け てしまう”感じが強く，必ずしもブロックの結果に満足 を示さなかった、ブロック効果の消失後の音声は，施行 前と全く同様の㾏攣性特徵を示した.今回はこのうち 1 例（59歳女性）について，ブロック施行前後の音声をテ ープで紹介した.

考 察 : 本症に対する反回神経切断術の評価は, 米国 でも一定していない. しかし Dedo のもとには, 米国内 各地から，かなりの数の症例が送られて扣り，その多く が重症であるためか，患者自身はその結果に満足してい る例が多いという．われわれは現在までのところ切断術 
を施行していないが，少なくともブロックによって压迫 性ないし凐攣性音声が消失することは確実である。な拉 一側の神経ブロックで，施行前両側にみられた痤攣性の 所見が消失することは, 強い痓攣性の声門閉鎖の成立 に, ある種の feedback の関与を示唆すると考光るべき か否か, 興味ある点であろら、今後本症の成立あるいは ブロック効果について基礎的検討を加光，また患者の希 望や満足度を重視しながら手術的療法を開発していきた い.この場合，選択的内転筋枝切断術（岩村）は，採る べき最良の手段であるらと考えている。

\section{文 献}

1) Luchsinger, R. et al.:Voice, speech, language. Wadsworth Publ. Comp., Belmont, 1965.

2) Dedo, H.H.: Recurrent laryngeal nerve section for spastic dysphonia. Ann. Otol., $85: 451-45$ 9. 1976.

質 問 : 東北大・永淵正昭 ブロックの回数を增すと 効果はよくなるか.

忍答 : 東大・広瀬 䜿 ブロック回数としては最高
3 回程度であるが, 毎回, 同様の効果を得ている.

質 問：金沢大・鈴木重忠 私どもの経験では，反回 神経をブロックしえる率は低かった。ブロックの方法は いかが、

応 答: 東大・広瀬 監 われわれは, 当初, 左反回 神経の本幹を狙って，ブロックを行ったが，現在は，右 輪状甲状関節付近を组い, 3 力所にわけ, 計 $6 \mathrm{~m} l$ 程度 のキシロカインブロックを行っている．狙った神経に当 たらなかった場合も，経験している。

質 問 : 長崎大・佐藤意生 痤攣性発声障害は両側声 带に生じているわけだが，一側反回神経ブロックによっ てなぜ回復すると考えるか。

応答：東 大・広瀬 蔀 一側のブロックで両側に みられる痙戀が消失するメカニズムについて Dedoは， 求心性インパルスが遮断されるためであるらととな兄て いるが，疑問がないわけではない，現在われわれとして も明確な解答をもって拁らず，今後の検討にまちたいと 思う。

52. 声帯癌における仮声帯移動術施行後の音声

\section{慶応大学耳鼻科 佐藤 学, 斉藤 成司, 福田 宏之} 岡本 亮二, 田村 宏之, 市川 忠

初期声带癌 (ここでは片側声帯に限局し, 前連合, 声 帯突起を越えず，声帯運動制限のないものをさす）に対 して，できるだけ良質な術後音声を得る 1 つの方法とし て，われわれは切除した声帯の欠損部分に仮声带を有茥 粘膜弁として移動させる仮声带移動術を行っている. そ の手術手技などはすでに報告し，1976年より現在に至る まで 7 例の症例を経験した。それらの症例の術後音声は 聴覚的にもかなり満足したものが得られている。これら の音声を, 発声持続時間 (maximum phonation time, M.P.T.), 強さ (ここでは maximum intensity と minimum intensity の幅, dynamic range, D.R. につい $\tau$ ), 声域 (vocal range, V. R.), 話声位 (mean speaking frequency, M.S.F.), 発声時呼気流率 (air flow rate, A.F.R. ここでは起声より 4”の平均), 聴覚的印 象につき検討した。

症例は, 43〜 76歳の男性 7 例で, すべて声帯癌 $\mathrm{T}_{1} \mathrm{~N}_{0}$ $\mathrm{M}_{0}$ であり, 術後経過 2 年 1 力月〜 9 カ月で, 現在のと ころ再発はみられていない。

- 症例 I（76歳） M.P.T. : 13", V.R. 95 290Hz（Fis $\sim \mathrm{d}^{1}$ 19半音), M.S.F. : $140 \mathrm{~Hz}$ (cis), A.F.R. : $420 \mathrm{ml} /$ sec, 軽度嗄声 (気息性).

- 症例 II (43歳) M.P.T. : 14"， D.R. : 24dB, V.R. : 1 $10 \sim 400 \mathrm{~Hz}$ (A $\sim \mathrm{g}^{1} 22$ 半音), M.S.F. : $130 \mathrm{~Hz}$ (c), A.F. R. : $160 \mathrm{~m} l / \mathrm{sec}$, 汪济正常.

- 症例吕 (68歳) M.P.T. : 21", D.R. : 20dB, V.R. : 1 $70 \sim 405 \mathrm{~Hz}$ (f $\sim \mathrm{g}^{1} 14$ 半音), M.S.F. : $220 \mathrm{~Hz}$ (a), A.F.R. $: 200 \mathrm{~m} l / \mathrm{sec}$, 㪕度嗄声 (気息性).

- 症例IV (64歳) M.P.T. : $14^{\prime \prime}$, D.R. : 13dB, V.R. : 10 $5 \sim 210 \mathrm{~Hz}$ (Gis $\sim$ gis 12 半音), M.S.F. : $130 \mathrm{~Hz}$ (c), A. F.R. : $250 \mathrm{ml} / \mathrm{sec}$, ほぼ正常.

- 症例 V (66歳) M.P.T. : $32^{\prime \prime}$, D.R. : 28dB, V.R. : $120 \sim 340 \mathrm{~Hz}$ ( $\mathrm{H} \sim \mathrm{e}^{1} 17$ 半音), M.S.F. : $140 \mathrm{~Hz}$ (cis), A.F.R. : $120 \mathrm{~m} l / \mathrm{sec}$, 注涪正常.

- 症例VI (64歳) M.P.T. : $26^{\prime \prime}$, V.R. : 125 $560 \mathrm{~Hz}$ (H $\sim$ cis $^{2} 26$ 半音), M.S.F. : $140 \mathrm{~Hz}$ (cis), A.F.R. : $150 \mathrm{~m} l /$ $\mathrm{sec}$, 軽度嗄声 (粗粘性).

- 症例VII (52歳) M.P.T. : 8", D.R. : 15dB, V.R. : 90 $\sim 270 \mathrm{~Hz}$ (Fis $\sim$ cis $^{1} 19$ 半音), M.S.F. : $130 \mathrm{~Hz}$ (c), A.F. 
R. : $540 \mathrm{ml} / \mathrm{sec}$, 嗄声 (粗䊁性, 気息性).

以上を各項目にまとめてみると，

i ) 発声持続時間 : $8^{\prime \prime} \sim 32^{\prime \prime}$, 平均 $18.3^{\prime \prime}$ でやはりや や低值を示しているが，一応満足すべき值と考えてい る.

ii）強さ（ここでは dynamic range について）: 13 $\sim 28 \mathrm{~dB}$, 平均 $20 \mathrm{~dB}$ で, 当科に沶ける正常者 10 名の平均 $32.5 \mathrm{~dB}$ に比べ，やはり低値を示した.

iii）声域 : 12 ～26半音で平均 18.4 半音であった. 声域 としてはかなり狭くなっている.

iv）話声位 : c a で，話声位はやや高値を示した。

v ）発声時呼気流率 : $120 \sim 540 \mathrm{ml} / \mathrm{sec}$ で平均 $282 \mathrm{ml} /$ sec であり，症例によってかなりのばらつきがあるが， やはり高値を示していると言える.

以上のごとく，声帯切除後の音声としてまず問題とな る声門閉鎖不全に関して, 発声持続時間, 発声時呼気流
率の面から考察するに，まず満足すべきものと考えてい る. dynamic range に関しては，かなり低值を示し， また声域に関しても正常者に比べ狭くなっていて, 話声 位もやや上昇している.これは移動した仮声帯の物理的 特性の問題と考えられるが，一応全例に拉いて 1 オクタ 一ブ以上の声域が得られ，音声機能の面から十分と思わ れる．社会生活上にも満足すべき音声と考えている.

参考文献 : 斎藤成司 : 発声機構の基礎的研究および喉 頭内腔への臨床的アプローチ. 耳鼻と臨床, 23 : 補冊 1 : 367 378, 1976.

質 問：名保衛大・岩田重信 $T_{1}$ で前連合部に近い ものに対してはいかにしておられるか.

応答 : 度大・佐藤 学 原則的に前連合に接近した Tumor では，この手術は行わないことにしている（腫 瘍の切除に際しては境界部より最低 $5 \mathrm{~mm}$ は健常組織も 切除している).

53. 輪状披裂関節の病態について

ーリュウマチ疾患を中心に一

横浜市立大学耳鼻咽喉科 大石 公直, 鯨井 和朗, 沢木 修二 東京大学音声言語医学研究施設 広瀬 肇

欧米では,リュウマチ様関節炎の患者に，嗄声・呼吸 困難などの症状が生じる例は, 比較的多く報告され，原因 として，輪状披裂関節部の異常にもとづくといわれてい る，わが国では，その報告例は少なく，平井，谷のそれ ぞれ 1 例と, 斉藤の 3 例と, 第30回気管食道科学会で報 告したわれわれの 1 例を加え，6 例にすぎない.今回， 整形外科リュウマチ外来に拈いて，48例の喉頭を観察 し，若干の知見を得たので報告した。

(1) 輪状披裂関節炎の症状といわれている咳・㫶下痛 などを有する症例は，21例で，このうち他覚的な所見の 得られたもの（披裂運動制限等）は，12例であった。こ れに症状は自覚しないが，所見のみられた 2 例を加え， 14例を調査の対照とした.

（2）リュウマチ様関節炎の程度を表すのに, stage, class 分類があり，上記14例をこれにあてはめてみると， stage, class が上がるに平行して，すなわち，リュウマ チ病変が進むにつれて, 病的な例の占める割合が増加し ていた.しかし，有意の差はみられなかった。

(3) 症状は, 咳・曖下痛が多く，8例にみられ，嗄声 ・呼吸困難を訴えたのは 2 例のみであった.
(4) 得られた所見では，披裂部の発赤・腫脹が 6 例に みられ，次いで，披裂部の運動制限が 5 例にみられた. 両側声帯正中位固定は 1 例のみであった.

リュウマチ様関節炎の患者に, 嗄声・呼吸困難などの 症状がみられ，リュウマチ様变化が輪状披裂関節に及ん だ症例の報告は，わが国では少なく，平井 (1936), 谷 (1966)，がその症例とともに言及しているにすぎない. また，斉藤ら(1978)は，リュウマチ患者の喉頭気管軟骨 形成異常の症例を報告している. 今回の，われわれの調 查の結果でも，嗄声を来たすほどの披裂運動制限は少な く，いずれも外転障害であり，正中位固定を来たしたも のは，わずかに 1 例であった. さらに，外転制限の原因 が必ずしも輪状披裂関節炎とは断定できず，その最終診 断は, 同関節部の病理組織診断によらざるを得ない。こ の点に着目し, 今後の課題としたい.

質 問 : 東大・小林武夫 両側正中位固定時の際に, 披裂部にさわってみたか. 披裂部の発赤には特徵がある か.

応答：横浜市大・大石公直 両側声帯正中位固定を 来たした 1 例の声門開大術の際に，披裂部の可動性を調 
ベたが，動きはなく，固かった．披裂部の発赤は，特に 強いという例はなく, 慢性炎症の軽度の発赤という印像 を受けた。

質 問 : 名保衛大・岩田重信 リュウマチ性喉頭炎と 診断する「こつ」をお教示いただきたい。

応答 : 横浜市大・大石公直 前頸部の触診で, 輪状 甲状関節部の圧痛があるかどらかを一つの所見としてい る.

質 問 : 東京聥信・法水正文 披裂軟骨膜炎などとの
鑑別診断および, 治療法の経験についてご教示乞う.

応 答 : 横浜市大・大石公直 軟骨膜炎との鑑別診断 は，一側の披裂軟骨の発赤があり，乙か子披裂運動制限 がみられ，前頸部の圧痛が一側性であれば，リュウマチ 様の披裂輪状関節炎と考光る．治療は，声帯正中位固定 を来たした 1 例の声門開大術以外は，患者の症状も少な く，整形で，ステロイドなど内服しているので，耳鼻科 では行っていない。

\section{4. 食道音声に対する携帯用増幅器}

\section{長崎大学耳鼻咽喉科 山口 司, 佐藤 意生, 山口 良二}

著者らは喉頭摘出者の食道による発声訓練プログラム を毎週 1 回開いている. 現在の参加者は37名で， 1 回の 指導時間は 1 時間30分である. プログラムの内容は, (1) 術前の患者に対するオリエンテーション，(2)術後の初心 者に対する食道発声法の解説と指導, (3)上達者による体 験的助言，(4)上達者の情報交換，である.

食道発声で日常会話を一応こなせるようになった上達 者でも, 環境騒音中での会話, あるいは口演時に, 疲労 と困難を感じていることが，わかってきた.

そこで，この問題を解決するために，補助手段として 音声増幅器を利用することを検討し，その試作器を $\mathrm{R}$ 社 に依頼した，それを食道発声の上達者に使用させ，その 感想や意見をもとにして，特にマイクロホンの構造に改 良を加えてきた。

音声増幅器の説計上の最大の問題点は音声入力マイク ロホンと出カスピーカを自由音場の至近距離で使用する ことからくるハウリングの発生であり, 次に重量と取り 扱い上の問題であった.

当初はマイクロホンと増幅器本体とを約 $50 \mathrm{~cm}$ のコー ドで接続するようにし，音声はパイプの入口ょり伝 導 し，マイクロホンに入感するようにした. しかし，この 方式は携带に不便であることが使用者から指摘されたの で，パイプに代わるマイクロホンの保持体を立方体のゴ ム製にし，直径 $1 \mathrm{~mm}$ の穴を 1 カ所に設け，音声の導入 部とした。

使用方法は増幅器本体を胸ポヶットに入れ, 電源スイ ッチをONにし，マイクロホンを片側の手で持ちながら 口唇に接近させて発声する。
成績としては，䀣念されたハウリングの発生は皆無で はないが，装用時に少し注意して取り扱えば，会話に支 障をきたすような不快音は発生しない，使用者全員の所 感を要約すると，全員が積極的に利用したいということ である．ただし，増幅器の本体を可能な限り小型軽量化 することと装用と取り扱いを簡単に，例えばマイクロホ ンの取り出しと電源スイッチの操作を一挙動でできるよ うにするなどの改良の余地が残されている.

なお, 増幅器の仕様は次のとおりである.

(1) 増幅器：トランジスタ式プッシュプル

(2) 周波数特性: $500 \mathrm{~Hz} \sim 5 \mathrm{kHz}$ フラット

(3) マイクロホン：マグネチック式

(4) スピーカ: $8 \Omega, 0.3 \mathrm{~W}$

(5) 電源 : $1.5 \mathrm{~V}$ 電池 2 個

(6) 重量 : 220 グラム

(7) 本体の寸法：高さ $9.5 \mathrm{~cm}$, 幅 $6.5 \mathrm{~cm}$, 厚さ $2.5 \mathrm{~cm}$

質 問: 名保衛大・岩田重信 雑音成分 (口腔内) は, どの程度か. 明瞭度が障害されるか.

応答 : 長崎大・山口 司 増幅器内部からの雑音は ほとんどなく，会話には支障ない。

質 問 : 大阪医大・高橋宏明 食道発声の長所は器具 そ必要としない点であるが，増幅器を用いるととの長所 がそこなわれる。それなら人工喉頭使用でよいではない か.

応答：長崎大・山口 司 食道発声訓練グループの 人たちは人工喉頭は使用したがらないので，その使用は 考えていない. 


\section{5. 発吃直後の吃音幼児}

愛知県総合保健センター聴力音声言語診断部 国島喜久夫, 国島 典子, 幸田 政次 築山 高彦, 藤田 菊江

発吃や予後を支配する要因をさぐるためには，発吃 （親が自分の子どもが吃音であると見なすこと，あるい はその時）直後の症例の実態を分析し，経過を追らこと が有効な手段の 1 つであると思われる. 今回は発吃時・ 初診時の言語症状, その後の経過を, 発吃後約 1 力月以 内に来所した症例について調べることにした．以下に対 象の性別と初診年齢を示す.

$\begin{array}{llll}\text { (1)女 } 2: 0 & \text { (5)女 } 3: 2 & \text { (9)男 } 2: 5 \text { (13)男 } 1: 11\end{array}$

(2)男 $3: 10$ (6)男 $3: 1$ (10)男 $3: 4$ (14)男 $2: 3$

(3)男 $2: 5$ (7)女 $3: 4$ (11)男 $3: 2$ (15)女 $3: 11$

$\begin{array}{lllll}\text { (4)女 } 2: 2 & \text { (8)女 } 3: 11 & \text { (12)女 } 3: 3 & \text { (16)女 } 3: 8\end{array}$ 発吃時の言語症状は母親の陳述に基づく，初診時の言 語症状の分析は母親同伴で面接を受けた際の親との，ま た面接者との会話の録音を再生，文字化し， 3 名以上の 言語治療士が同時に聴取し, 本学会吃音娭査法委員会に よる分類に基づき，意見の一致したものを採用した．経 過は言語環境の調整に重点を置いた指導を受けながらの ものである。

結 果: 発吃時の言語佂状; 語頭音節の繰り返し 13 例, 語頭音節の繰り返しとブロック 1 例, 引き伸ばし 1 例, 不明 1 例.

(2)初診時の言語怔状；1)総吃頻度 $(\%)$ 算出方法, 総 吃文節数総 $\div$ 総文節数 $\times 100$ (1) 12 ，(2) 2 ，(3) $11 ，(4) 26$, (5) 17 , (6) 1 , (7) 24, (8) 33 , (9) 47 , (10) 28 , (11) 51 , (12) 5 , (13) 59, (14) 14, (15) 19, (16)発語なし，2）症状カテゴリー別吃 頻度 $(\%)$ 算出方法, 症状カテゴリ一別吃文節数 $\div$ 総吃 文節数 $\times 100$, 音声言語医学 Vol.19 No.1, 1978, 1, p. 145. 表1言語症状分類の症状カテゴリ一の欄に上から順 にアルファベットをふり, それに従って以下に示す. (1) A11, I 78, A I 11. (2) A100. (3) A56, A B22,"A C 22. (4) $\mathrm{A} 13, \mathrm{~B} 58, \mathrm{AB} 26, \mathrm{~B} \mathrm{I} 3$. (5) $\mathrm{A} 93, \mathrm{H} 4, \mathrm{~A}$ G 4. (6) A 100. (7) A 30, I 50, A I 10, G I 5, H I 5. (8) A27, I 23, A B41, A I 5, A K5. (9) A84, G 2, A G 2, A I 2, AK7. (10) A67, I 8, A D8, A I 17 . (11) $\mathrm{A} 43, \mathrm{~B} 14, \mathrm{AB} 38, \mathrm{AEF} 5$. (12) $\mathrm{A} 50, \mathrm{~K} 25, \mathrm{ABK}$ 25. (13) $\mathrm{A} 20, \mathrm{~B} 3, \mathrm{I} 63, \mathrm{~A} \mathrm{~B} 10$. (14) I 80, I K20.
(15) A22, D11, I 11, L44, A L11. (16)-

(3)経過； (6は初診時すでに吃音はほとんどみられなか ったが，その後20カ月経過した現在にいたるまで吃音は あらわれていない. (16)初診時に本人の発語が得られ ず，またそれ以後来所しなかったが，初診以後吃音がみ られなくなっていることが，4 カ月後の現在判明してい る. (10は初診時にある程度の吃症状がみられたが， 3 カ 月後頃から改善がみられ，19力月後の現在にいたるま で，その調子が持続している。 (5)初揨後改善がみられ たとのことで来所しなくなったが，14カ月後の現在は吃 咅がみられるようである. (2)(3)(7)(8)(9)(11)(12)(13)(14)について は，全般的に改善の傾向にある. (1)はあまり変化がみら れないうちに転居している. (4)(15は初診後日も浅いこと もあるが，変化はあらわれていない。

まとめ：発吃時, 初診時の言語症状から今回の対象に は，正常範囲の非流暢さと久なしてよいもの，そうでな いもの两方が存在していると思われる．前者はもちろん 予後が良好であるが，後者でも改善した症例があり，末 た全般的にはその傾向にある.どんな症例でも，少なく とも環境からくる二次的な問題は子防できる可能性があ る点では, 早期指導は重要である. 今後は発吃後長時間 経過してから来所したものとの比較検討も試みてみた い.

質 問 : 京都言語障害研究会・梅原正之 対象となっ た幼児について，具体的な指導治療をされたのかどう か.

応答 : 愛知県総合保健センター・国岛書久夫 直接 子どもに対して, 対症療法的指導は行っていない. 将米 的には子どもによって，直接指導が必要な場合があると 考えている. 発吃まむない子どもへの直接指導の具体的 方法は，現在まだつかめていない。

質 問 : 筑波大・内須川洸 今回発表のあった発吃後 1 力月以内に受㟝した症例16例は，受診全例の何\%に相 当しているか，受榙例の大半は，癷吃後長期間に及ぶ場 合を体験していると思われるので.

応 答 : 愛知県総合保健センター・国岛喜久夫 発吃 
直後から相談にくる症例は確かに少ない、吃音を主訴で 来所する全症例の中で占める割合は，算出していないの で, 正確にはわからない.

質 問：金沢大・能登谷晶子 発症から 6 力月経過し ても, 改善しないものは, 予後が悪いと考光てよいか.
後 6 力月を過ぎても軽減しないものか，予後不良とは限 らない、しかしながら発吃後 1 力月以内か軽減しはじ め，4 力月後には臣とんど吃音がみられなくなる症例が ある、それ以降でも，軽減することがあるが，波がある ことが多い，さらに長期にわたる観察が必要である.

質 問 : 愛知県総合保健センター・国島喜久夫 発吃

\title{
56. 吃音の適応性効果と一貫性効果について
}

\author{
国立聴力言浯障害センター 森山 晴之 \\ 神奈川県総合リハビリテーションセンター 赤星俊 \\ 同立聴力言語障害センター 土井明
}

成人吃音者 34 名に，53文節からなる散文朗読を，連続 して 5 回課し, その適応性効果と一貫性効果に関する検 討を行った。適応性効果と一貫性効果の算出は, Johnson ら（1952）の方法に従った.

適応性効果は, 平均 $32.1 \%(100 \sim-100 \%)$, 創話時 発話量との間に, 低い相関 (.374: Pearson's) が認めら れ, 初回朗読吃頻度, 所要時間, 一貫性, 創話時吃頻度 など, 他の測度との相関は, いずれも, さらに低かっ た.

一貫性効果は, 平均 $37.7 \%(0 \sim 100 \%)$, 初回朗 読吃 頻度, 創話時吃頻度との閒に有意相関 $(.708, .628)$ を 認めた．概して，適応性に比して，一貫性のほうが，他 の測度との間に強い相関を示した。

朗読に扣ける適応性が高かった者, 一貫性が低かった 者は，創話時における時間あたりの発話量が多く，吃音 頻度も低く，従来の見解之同椂の傾向であったが，この 巡は, 明確ではなかった。たとえば, 初回朗読, 創話時 ともに，吃頻度が低かった者のらち，朗読に括ける適応 性が高く，一貫性が低かった者は半数弱のみであった.

適応効果が認められなかった者 9 名 $(27 \%)$ は, 創話 時にも吃頻度が高く, 発話量も少なかった。また, 初回 朗読時の吃頻度が50/文節\%を超えた者 6 名は, 適応性 が一貫性より低く，一貫性が特に高かった。

言語症状について, 初回朗読時の吃頻度が低かった者 （3.7/文節\%】） 7 名と，吃頻度が高かった者（50／ 文節\%个）6 名を比較すると，「音や音節の繰り返し」 が全吃症状に占める割合は, 両群に類同 (35.6\%: 33.2 \%)であったが，「挿入」は，高吃頻度群に多く，(5.1 $\%: 28.9 \%)$,「ブロック」「間」は高吃頻度群のみに認 められ，両群間の差は有意であった $\left(\lambda^{2} \alpha=0.05\right)$.
適応性と一貫性の程度により，適応性 が高く（80\% $\uparrow)$, 一貫性が低い $(33 \% \downarrow)$ 者= A群 (7 名), 適応性 が低く $(46 \% \downarrow)$, 一貫性が高い $(50 \% \uparrow)$ 者=B群 (6

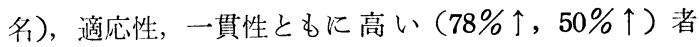
=C群 (3 名) に分けて症状を比較すると, A 群は, 「言い間違い」(24.1\%)，「とぎれ」(15.2\%) の占める 割合が， B C 群に比して有意に多かった ( $\left.\lambda^{2} \alpha=0.05\right)$. 一方, $\mathrm{BC}$ 群は, 症状の可半数を「繰り返し」と「挿 入」が占め, 類同の傾向を示した.

症状の可変性の観点から, DAF 下のスピーチを参照 すると, DAF 下の創話時最低吃頻度が, 創話時 NAF吃 頻度 $(\gamma=.75)$, 初回朗読時間 $(\gamma=.72)$, 一貫性 $(\gamma=$ .53）との間に，それぞれ有意相関を示したが，適応性 との相関は低かった $(\gamma=.14)$.

DAF による言語症状の变化について, DAF 効果群 (効果率 $76 \% \uparrow$ ) 8 名, マイナス効果群 $(0 \% \downarrow) 9$ 名 を比較すると, 効果群は, マイナス効果群に比して, N $\mathrm{F}$ 時に多彩な言語症状を示したが，DAF 下では，「繰 り返し」「插入」以外の症状が消失した. DAF が，「中 止」「緊張」「ブロック」「歪み」など, 主として, 緊 張成分の症状に働いたと考兄られる. マイナス効果群 は，NF時には，「繰り返し」「摴入」「引伸ばし」が， 症状の大半を占めたが, DAF 下では,「繰り返し」が増 えるとともに, 症状の種類が增兄, 対照正常群の DAF 下のスピーチとの類似性が認められた。

以上, 適応性に比して, 一貫性のほうが, 他の側面と の関連に扔いて, 吃音特徵をあらわす測度としての可能 性が高いこと, 症状の可変性, たとえば, DAF 下のス ピーチとの関連も，比較的に一貫性のほうが強いことな どを報告し，併せて，言語症状との対応などについて考 
察した.

今回, とりあげなかった吃音特徵の他の側面 も含め て，さらに，検討することが必要である.

質 問 : 全国言友会連絡協議会・辻中 忍 (1)予後々 の関連は，今後の研究に待たなければとのことである が，朗読の適応性と一貫性を調べることによって，成人 吃音者の予後は推定できるものなのか.

(2)成人吃音者の予後を推定する場合，大きな要因とし てはどのよらなものが考兄れるか。

芯 答 : 国立聴言センター・森山晴之 今回は, 両指 標の吃音特徵をあらわす測度としての意義について検討
した. 予後との関連で中には, 縦断研究が必要である.

(2)現状では不明である.心理的な要素も重要であろう と思われる。

質 問：京都言語障害研究会・梅原正之 対象となっ た成人吃音者 33 名の個人的な面特に職業, 学業歴などに 考虑を払われたのかどうか，もし払われていないのなら その理由を扣きかせ願いたい，

応 答 : 国立聴言センター・森山晴之 生活面などに ついて, 生育歴・自己評価をとってあるので, 参照可能 であるが，今回は，適応性，一貫性の程度と吃音症状， 発話特徵との対応関係について調べた。

57. 吃音児と普通児の非流暢性の比較

はじめに : 従来, delayed auditory feedback (DAF) を用いた言語機能の研究が数多くなされてきており，そ のいくつかの側面が明らかになってきた。 しかし，これ までの研究にはDAF を負荷した際の, 被験者内変動に 観点をあてたものは少ない. DAF を用いた吃音の研究 においても, 個々の delay time での発話, 特に吃症状 の減少，または增加する delay time に観点をあてた ものがほとんどである，そこで本研究では, normal auditory feed back (NAF) と， 3 つの delay time での DAF 負荷という 4 条件を連続的に与え, 被験者内变動 を普通児と吃音児で比較することを目的にした。

方 法: 装置は DAF-34 (TRIO) を用いた。被験者 は, 普通児10名（平均年齢 9 歳 6 力月), 吃音児10名(平 均年齢 9 歳) で, 両群とも以前に DAF の経験はなかっ た. 音読材料は, 小学校 1,2 年生レベルの文章で, 59 文節から構成されていた。全被験者に NAF と DAF 負荷 (delay time は0.1，0.2，0.3秒）で，1回ずつ計 4 回, この順序で音読させた. 検討項目は, (1)音読時間 と, (2)非流暢性頻度, の 2 項目であった. 非流暢性頻度 の測定のために， 7 項目の尺度（絽り返し，引き伸ば し, 中断, 省略, 付加, 言い直し, 言い誤り)を設け た。そして，それぞれの尺度に対応する事象が 1 回起こ るごとに，頻度 1 とした。

結 果 : 音読時間について両群の delay time に伴う 変動を比較すると，普通児群は delay time の変化に伴 いわずかに測定值が上下するだけであり，個人差も小 さかった.これに対して吃音児群は， delay time の変 化に伴い，測定值が大きく上下しており，個人差も非常

\section{東北大学教育学部 伊藤 友彦}

に大きかった．この傾向は，非流暢性頻度についても同 様にみられた。

そこで，(1)音読時間と，(2)非流暢性頻度の被験者内変 動を，それぞれ 4 回の測定值の標準偏差であらわしてみ た。まず，音読時間における標準偏差でとらえた変動幅 は，普通児群においては，平均 5.2 (2.3〜 7.7) であっ た.これに対して吃音児群では平均 13.0 (3.6〜39.2) であった．次に非流暢性頻度における変動幅は，普通児 群においては平均が1.8（0.6〜3.1）であり，吃音巟群 では平均5.3（0.5〜12.8）であった，検定の結果，音読 時間においても，非流暢性頻度においても，吃音児群の ほうが普通児群よりも，有意に変動の大きいことがわか った。

考 察: 今回の実験の結果は, auditory feedback に 対して時間的変化を与えた場合，吃音児群のほうが普通 児群よりも，その影響を強く受けやすいことを示してい る.このことは，吃音児群が普通児群よりも，発表にお ける時間的な feedback control function が劣っている ことによると考えられる.

しかし，音読時間においても非流暢性頻度において も，吃音児群の個人差は非常に大きく，普通児群に近い 変動幅を示すものから，非常にかけ離れて大きい変動幅 を示すものまであった．この個人差が何に起因するもの かは，今後検討していきたい.

また，両群とも音読時間と非流暢性頻度における変動 幅の間に相関はなかった.このことから，音読時間と， ことばの誤りに対する DAF の影響は別々のものであ ると考えられる. 
58. 反回神経ブロックによる吃行動の変化

金沢大学耳鼻咽喉科 鈴木 重忠, 能登谷晶子, 中島美喜子, 前坂 明男

はじめに : これまでの吃についての研究は, 中枢性の 障害としてや，心理的側面からのアプローチが主流を占 めていた. しかし，最近では，内視鏡的観察で吃音時に おける，声門閉鎖や開大の異常が認められた報告がなさ れるなど，未梢器官機能の異常にも注目される方向にあ る.われわれも昨年度, 本学会で電気喉頭使用時に吃が 消失することを報告し，吃発生時における声帯レベルの 異常を推測した.

このことから, 末梢に打ける吃症状の主体は, 声帯レ ベルでの機能異常によるものであること，この機能異常 は反回神経が支配する声門開大筋と閉鎖筋の協応不調に よることが考兄れる.

したがって, 声門開大筋と閉鎖筋（主として閉鎖筋 の）の機能を減弱すれば，吃症状が減少すると仮説され る.

今回われわれは，成人吃患者の協力を得て，一側反回 神経ブロックによりこの仮説を検討することができたの で，その成績を報告する.

対 象: 幼児期以来の成人吃者 2 名を対象とした. 症 例 1 は55歳男子で repetition+hesitation タイプ. 症例 2 は27歳男子で, block タイプである.

方 法: キシロカイン $0.5 \%$ 液 $5 \mathrm{cc}$ を右側甲状軟骨下 角と輪状軟骨との接合部目指して注入し, ブロック前・ 中・後の文章音読，拉よび検者との会話に括ける吃症状 と心理の変化を観察した.

音読に用いた文章は, 各症例が吃を予期しやすい音を 多く含む15～16文節文である. 音読時の吃頻度は, 各症 例に文章を音読させ吃頻度（音読時の吃頻度二吃った文 節数 $/ 15 \sim 16$ 文節) を求めた.

会話時のスピーチ・サンプルは,ブロック前・中・ 後, 各々10 30分間の会話を録音し, 会話時の吃頻度 （会話時に打ける吃頻度＝吃った文節数／1分間の発話 文節数)を求めた.

結果および考察：症例 1 のブロック前・中・後におけ る音読時の吃頻度は，それぞれ $52 \cdot 11 \cdot 25 \%$ ，会話時の 吃頻度は，それぞれ47.5・17.7・31.3\%であり，音読時 および会話時においてブロック中吃頻度が減少した.

症例 2 のブロック前・中・後の音読時に抢ける吃頻度
は，それぞれ13.3・0・0\%と減少した。また，会話時の 吃頻度は，それぞれ19.6・20.8・20.5\%で著変はなかっ たが, ブロック中で発話量の増加が認められた。吃の難 発時間の平均は, それぞれ $3.4 \cdot 1.1 \cdot 3.2$ 秒であり,ブロ ック中に軽減をみた。なお，本例では反回神経後枝のみ をブロックした時には，吃症状がかえって増悪した。

心理面の吃予期反応については, 症例 1,2 ともに, ブロック前・中・後も著変はなかったと述べている.

以上のように, 症例 1 では音読時会話時共に, 一側反 回神経ブロック中に吃頻度が減少し, また, 症例 2 では 難発時間が短かくなるなど，2症例ともに吃症状の軽減 が認められた。これらの結果は, われわれが仮説した, 末梢器官である声帯レベルにおける吃症状のコントロー ルを支持すると考兄られ，今後神経外科的治療や向神経 薬物治療による吃の治療の可能性が示唆されたといえよ う.

まとめ: 成人吃 2 例に対して, 一側反回神経ブロック による吃行動の変化を観察し, 次の結論を得た.

(1)一側反回神経ブロックにより 2 症例ともに吃症状の 軽減を示した.

(2)心理面の吃予期反応は，2 例ともブロック前・中・ 後で著変はなかった。

(3)吃の神経外科的治療拉よび薬物療法の可能性が示唆 された。

質 問 : 愛知県総合保健センター・国岛典子ブロッ ク後の吃症状をとられているが，注入後どれくらいたっ た時点で測定されたのか，またこの状態はどのくらい持 続するものか.

第 2 例の音読材料は同一のものか，別のものか，また 第 2 例の音読時適応効果はどのくらいか, 調べてある か.

応 答: 金沢大・鈴木重忠 注入数分後から約 10 分間 マヒが持続する. その後, 徐々に解除し， $30 \sim 40$ 分後に は正常となる.

各例の難発音を語頭に多く含む文を使用した。したが って，2例の音読文は異なっている. 今回の音読の適応 効果はみていない. 


\section{第VIII群 構 音 (I )}

\section{9. 口蓋筋機能の再検討}

\section{関西医科大学耳鼻咽喉科 本庄厳, 岡崎 伸博, 野添 恒幹}

いわゆる口蓋筋とされるものに，口蓋帆挙筋，口蓋帆 張筋, 口蓋垂筋, 口蓋舌筋, 口蓋咽頭筋の 5 筋があり, らち口蓋の機能上特に重要とみなされる筋肉は口蓋帆挙 筋と口蓋帆張筋の 2 筋である. しかしこれらの筋肉は, 一方では耳管を開大せしめる耳管筋とされており，1つ の筋肉が同時に 2 つ機能を兼ねる点, なお検討の余地 があると考えられた. 本研究ではこれら 2 筋の口蓋運動 と, 耳管機能における実質的な役割を, 実験的, 臨床的 方法で明らかにした.

\section{1. 犬口蓋帆挙筋, 張筋の電気刺激実験}

a. 口蓋運動の観察：ネンブタール麻酔，気管切開の 後, 経口蓋的に挙筋, 張筋を露出, これに双極鉤電極を 刺入し, 挙筋, 張筋を単独あるいは同時に電気刺激し た. 一方この際の軟口蓋運動を force transducer を用 いて電気的に記録した. その結果, 挙筋の電気刺激は著 明な口蓋挙上運動をもたらすが, 張筋刺激では, 刺激閥 值を高めても口蓋全体としての運動は全く認められず, わずかに翼突鉤付近の攣縮を認めたのみであった。 また 挙筋, 張筋の同時刺激実験でも, 張筋の口蓋運動に対す る影響は実質的には無視し得ることが判った.

以上まとめると口蓋の主要筋は口蓋帆挙筋であり, 一 方口蓋帆張筋は口蓋運動には関与しないといえる.

b . 耳管機能の観察 : 同じく経口蓋的に挙筋, 張筋を 露出して電極を刺入し，これを電気的に刺激した. 一方 この際の耳管開大運動を外耳道圧の変化として 記 録し た.この結果, 張筋の電気刺激では, きわめて弱い刺激 闘値で耳管が開大するのに反し，挙筋刺激では，電気刺 激闘值をいくら高めても耳管開大が起こらぬことが確認 された.すなわち挙笳は耳管開大に関与せず, 張筋のみ
が耳管開大を行っていることが確認された.

\section{2 . 臨床的観察結果}

高度耳管開放症例に対し，治療の目的で両口蓋帆張朌 切断術を行った症例につき, 術前後の口蓋運動を視診と 発声, 嶼下時のレ線フィルム, 造影レ線映画により観察 した結果，口蓋の緊張低下，口蓋挙上運動の減弱などの 所見を全く認めず，人においても口蓋帆張筋の口蓋機能 への関与は無視し得ることが判った。

また，笳電図学的に口蓋帆挙笳のみの麻㽻が証明され た軟口蓋麻疸患者につき，その耳管機能を検査したとこ ろ，全例に正常耳管機能が証明され，人に拈いても口蓋 帆挙筋は耳管機能に関与せず，口蓋帆張笳がこれを行っ ていることが確認された.

以上をまとめると, 従来, 口蓋筋, あるいは耳管筋と 呼ばれてきた口蓋帆挙筋, 口蓄帆張筋の機能は各々大き く異なり, 挙筋はもっぱら口蓋機能をつかさどり, 一 方，張筋はこれには関与せず，耳管開大のみに寄与する 笳肉といい得る.

追 加：東大・新美成二 軟口蓋の動きを発話の面か らとらえ, 口蓋帆挙筋と上咽頭収縮筋の筋電図を観察 し, 口蓋帆挙筋は鼻音, 非鼻音の調節に主要な働きをす ることを確認した．それに対し上咽頭収縮筋は，鼻咽腔 閉鎖に対して特異的には活動しない.

質 問：金沢医大・相野田紀子 口蓋裂のような pathological case については, 両筋の機能はどうか.

応答: 関西医大・本庄 崖 口蓋裂例の挙筋は正常 に比して大きな走行異常があるが，張筋はほぼ差異がな く，したがってロ蓋形成術でこの筋を損傷しなければ, 耳管機能には大さな問題は起こらないと思われる. 


\title{
60. 口蓋化傾向について
}

ーレントゲン映画およびダイナミック・パラトグラムによる分析一

\author{
昭和大学形成外科 岡崎 恵子, 鬼塚 卓弥, 赤川 徹弥 \\ 東京大学耳鼻咽喉科 阿部 雅子 \\ 東京大学音声言語医学研究施設 沢島 政行 \\ 昭和大学第 1 口䐋外科 鈴木 規子
}

目 的：聴覚的に口蓋化傾向と判定している異常構音 について, 舌の動き, 構音点に関しその実態を解明す る.

対 象：19祡男子，左唇裂口蓋裂があり，唇裂の手術 は生後 5 力月および18歳 7 力月， 口蓋裂の手術は 1 歳 5 カ月にらけている. 鼻咽腔閉鎖機能は良好で開鼻声は ないが，構音の異常として/s/, /ts/, /dz/ の口蓋化が 認められる。口蓋に瘦孔および顕著な瘢痕はない，上顎 歯列弓は軽度の狭窄があり，前歯部，曰歯部はともに反 対咬合である。

分析の方法 : (1)35mm レントゲン映画により，患者の 右側面から発話時の附属管腔を撮影し，同時録音したソ ナグラムと照合する．(2)患者にリオン製の人工口蓋を装 着し，エレクトロ・パラトグラフに人工口蓋を接続す る.さらに，パラトグラフ用グラフィック・プリンター に接続して発話させる. 打出されたパラトグラムと同時 録音した音声のソナグラムを照合する．検査音は /s/, $/ \mathrm{ts} /, / \mathrm{dz} /$ を含む 2 音節の無意味語および 2 〜 音節よ りなる有意味語である。

結 果：(1)レントゲン映画による分析. /s/ が口蓋化 すると，舌背が徐々に挙上し，舌背と口蓋が汇とんど接 触するまで近接してせばめるつくり産出される．この場 合, 舌背の最も高い位置は硬口蓋後縁に対応する。/ts/ の口蓋化でも舌背が挙上するが，舌の前方が歯茎部に接 触しすぐ下降して破裂音を産出，ひきつついて舌背と口 蓋をせばめて摩擦音をつくる．この時の舌の形態は/s/ 発声時ときわめて類似している。/dz/の口蓋化は/s/の それとほとんど同じ所見で，この症例の場合，摩擦音で はなく, 摩擦音/z/の口蓋化の音として構音している.

(2)ダイナミック・パラトグラムによる分析，/s/ の口 蓋化は, 口蓋側の後方から舌の接触がはじまり, 前方お よび内側方向へ舌の接触が広がる. 接触が最大になった 時摩擦音が出はじめるが，この場合の舌の接触は，左右 側とも口蓋後方からほぼ 3 分の 1 で，口蓋の中央は接触 していない／ts/の口蓋化は，口蓋後方より歯列に沿っ
て舌の接触が進み, 同時に口蓋後方部では内側に向かっ て舌の接触が進む. 歯列に沿った前歯部の接触がほぼ完 成すると, 急速に歯列に沿って後方への解放が起こり, この時ソナグラム上破裂音が認められる. そのあと左右 両側の口蓋後方部の舌の接触を保持したまま摩擦音をつ くる. この時の舌の接触パターンは/s/のそれと類似し ているが，/s/の場合より口蓋前方まで舌の接触が広が っている．/dz/の口蓋化は/s/のそれとほとんど同じ舌 の接触バターンで, 接触, 解放の方向も同様であった.

まとめ: 聴覚的に口蓋化と判定された $/ \mathrm{s} /, / \mathrm{ts} /, / \mathrm{dz} /$ の各構音は，レントゲン映画およびダイナミック・パラ トグラムのいずれにおいても舌背が挙上し, 口蓋とのせ ばめをつくって摩擦音を産出していることが明らかにさ れた. 舌の接触が最も正中に寄る位置は, 硬口蓋後部で あり, 舌先は摩擦音の産出に関与していない.こうした 構音動作は，この症例に関しては一貫性があり，後続母 音による変化もほとんど認められなかった.

謝辞 ダイナミック・パラトグラムについてご指導いただい た国立聴力㝘語障害センタ一の柴田, 井野, 山下の諸先生に 感謝する.

質 問 : 東医雪大・吉增秀実 / ts / の口蓋化のなかに は/t/と/s/の両方が後方に移動する場合と, 本例のよう に/t/は正常な構音点で, /s/のみ後方に移動する場合と があるのか.

応答 : 昭和大・岡崎恵子 本症例は / $\mathrm{t} /$ が正常構音 であり，/ts/では/t/の破裂は歯茎部で，/s/の摩擦は口 蓋後方で行っている.

質 問：度大・武久恭子「口蓋化傾向」という用語 についてはな険討する必要があろうとして発表されて いるが, 今回, 構音点, 構音法について明らかにされた のなら，普通されている構音の表現法と同様に，「硬口 蓋摩擦音」（？)としたほらが解りやすい「「口蓋化傾向」 とは，歯音，歯茎音が口蓋に移行した構音の誤り全般を 意味していると受けとられ，また，さらに口蓋裂構音障 
害全体を表現しているように思われて，現在すでに用い られている．用語について検討をしていただきたい．

応答：昭和大 - 岡崎惠子 歯音・歯茥音に系統的に みられる異常構音なので, 口蓋化傾向といら用語をもち いている. 用語の妥当性については別の場で検討してほ しい. 口蓋裂の異常構音がすべて口蓋化傾向であるとい った表現はしたことがない.

質 問：九大・宮之下靖子 口蓋化傾向と口蓋形態と の関係はどうだったか. 正常人の口蓋形態との比較をさ
れたか。

「あさ」のソナグラムで, $\mathrm{s}$ 音のパターンについて, 正 常人と口蓋化傾向の患者とでは, 相違があったか.

応答 : 昭和大・岡崎恵子 本症例は上顎の狭窄があ り，前歯部，臼歯部ともに反対咬合である.19歳男子の 口蓋の形態との比較は行っていない.

現在訓練 中なので, ソナグラムでの比較は行ってい ない.

\section{1. 口蓋裂児の構音習得に関係する要因について}

$\begin{array}{rrc}\text { 慶応大学耳鼻科 } & \text { 武久 } & \text { 恭子, 桜井 } \\ \text { 産業医科大学耳鼻科 } & \text { 岡本 } & \text { 健 } \\ \text { 東海大学形成外科 } & \text { 長田 } & \text { 光博 } \\ \text { 東海大学耳鼻科 } & \text { 吉田 } \text { 泰行 }\end{array}$

栄, 村岡 純子, 松崎美津子, 蓮見 元子
口蓋裂形成手術は幼児期に行われる場合が多いが，術 後に必要とされる鼻咽腔閉鎖機能診断, ならびに構音の 予後判定として, 幼児に施行可能である gag reflex 時 の後鼻鏡による鼻咽腔閉鎖機能検査, ならびに構音検査 を継時的に行っている.

継時的な構音検査を行うことによって, 口内圧を必要 とする子音の表出が可能か, それが増加するか. 時に正 しくあるいは昰んで可能か, それが変化するか, または 口内压が作れないために子音部分がすべて省略される か,などから鼻咽腔閉鎖機能の良否を推測し，また構音 の悪習慣が長期間持続するかなどをみることができる. なおわれわれの資料では gag reflex 時所見, ならびに 構音の良・不全・不良の相互関係は，95\%一致してい る.

さらにこの継時的な構音検査結果に, 構音習得に関係 する要因として, 手術年齡, 構音習得期であることばの 反復期の開始, gag reflex 時の鼻咽腔閉鎖機能所見, 万 ら孔，難聴などを挿入することにより，幼児期の口蓋裂 形成手術後の構音習得過程に, これら要因がどのように 関係するかをみることができる.

われわれは, 構音検查結果の記載方法として, 5 母音 と子音十母音の音節から成立している日本語語音を I P $\mathrm{A}$ で表記し, 構音点と構音法に分類した構音検查票を作 成した.

この検査票に構音検査をしながら，ただちにそれぞれ 符号で, 正しい.... 歪文… $\triangle$, 省略…子音部分を/で
消す，置き換え…置き換えられた音節をI P A で記入す る，声門破裂音 $\cdots$ ?，鼻音…〜， その他上咽頭破裂音， 咽頭破裂音, 鼻雑音, 舌出し, 鼻性渋面などを記入す る.この検査票により，一見して構音の誤りと程度がわ かる.

さらに，これらの構音検査票を継時的に並べることに よって，構音習得経過をみることができる。

また，それぞれの子音群を評価したるのを縦軸に，年 齢を横軸にしてグラフにすると，構音習得の年龄的変化 がわかる.

初回手術を行い, gag reflex 時鼻咽腔閉鎖機能が術 後 3 カ月までに良と診断された例の術後, 口内圧を必要 とする子音の表出と習得は, 手術年齢ではなく, 構音習 得期であることばの反復と関係している，またことばの 反復がすべてに開始され，誤った構音を表出している過 程で手術が行われると，自然習得で正常構音になる。 たは，構音治療が必要な場合がある．また誤った構音が 習慣化された後に手術が行われた術後は, 構音の誤りは ほとんど变化せず, 構音治療が必要とされる.

初回手術後, 鼻咽腔閉鎖不良のため再手術を, ことば の反復前・反復中・反復後に行った場合, 再手術であっ ても初回手術と同様に, 鼻咽腔閉鎖機能が得られた時期 と, ことばの反復の時期との関係によって, 自然習得で 正常構音になる。または構音治療が必要になる.

gag reflex 時の嶴咽腔閉鎖機能不全の所見が持 続 し た構音習得過程は, 口内圧を必要とする子音部分の省略 
が多いが，また正しくあるいは歪んで可能である. 不全 例の場合は, ことばの反復とは関係なく, 再手術を行う と構音は改善される.

鼻腔にまで通じる $4 \times 4 \mathrm{~mm}$ くらい以上のろら孔は， 構音を作りにくくするが閉鎖することによって正常構音 となる。

難㯖, 構音刺激の不足, 構音連動の不器用, 著しい反 対咬合なども構音習得に関係する，などがわかる。

われわれは，以上のように術後口蓋裂幼児の構音検査
を継時的に行らことによって, 口内圧を必要とする子音 表出の良否, 構音習得に関係する要因の検討を行らとと もに, gag reflex 時の鼻咽腔閉鎖機能所見の良否とを あわせ, 再手術の適否, ならびにその再手術時期の選 択, 構音治療の要否の決定をしている.

追 加: 東北大・永淵正昭 32歳で口蓋裂手術を受け て，スピーチがほとんど正常に回復したケースをテープ で紹介した。

\section{Blowing Ratio による口蓋裂術後経過の評価}

はじめに : 口蓋裂術後の鼻咽腔閉鎖機能改善の経過を 経時的に追跡することは, 手術の評価, 予後の推測, 訓 練開始時期の決定などを行ら上できわめて重要である. しかしながら，手術後の経過を追跡した研究は非常に少 なく，さらに閉鎖機能を量的に経過追跡した研究は，中 田（1959）のもののみである.

私たちは，閉鎖機能を簡便にかつ定量的に評価するた めに, blowing ratio（相野田, 1978）を使用している. 今回は，この blowing ratioによって術後の閉鎖機能の 経過を追跡し，若干の知見を得たので報告する.

症例と方法：症例は24名（男11名, 女13名）で, 平均 年齢は16.6歳 ( $6 \sim 34$ 歳), 中 2 名は初回手術例で, 残 り22名は再手術例である. 術式は, pushback 法 2 例, bilateral lateral pharyngoplasty (BLP) 9 例, sandwich pushback 法 (S) 2 例, S と B L P 1 回ずつ 2 例, $\mathrm{S}$ と B L P 同時施行 2 例, re-pushback 5 例, その他 2 例であった. 術前の症例はすべて口蓋に著しい形態異 常を有し, blowing ratio の平均は $25 \%(0 \sim 80 \%)$ と 非常に悪かった.

結 果 : (1)blowing ratio の経過カーブによって, 症 例は次の 3 つのタイプに分類された. すなわち, 改善型 (17例), 不変型 ( 1 例), 改善・悪化型 ( 4 例) などで あった（他の 2 例は術後経過追跡期間が短かいため, 特 徵的なカーブがみられなかった).

(2)最終手術時期に blowing ratio が90\%以上飞改善し たものは15例 (63\%) で，90\%に到達した時期は術後半 月〜 3 カ月, 平均1.7カ月であった.

(3)不変型の 1 例は, 片側完全裂の 10 歳女子で, 手術歴 は次のごとくであった.すなわち 1 歳 8 カ月で初回手

\section{金沢医科大学耳鼻咽喉科 相野田紀子, 山下 公一 金沢医科大学形成外科塚田 貞夫, 斎藤 格}

術, 4 歳 8 力月で穿孔閉鎖術, 6 歳11 カ月で sandwich pushback, 7 歳 7 カ月で bilateral lateral pharyngoplasty, 8 歳 5 力月で唇再手術, 9 歳 9 カ月で pharyngeal flap 形成を行った. flap 形成後半月で blowing ratio は $100 \%$ 飞改善され，6カ月間の言語訓練によっ て重度の glottal stop は消失し正常スピーチを獲得し た。

(4)改善・悪化型 4 例飞ついて, 悪化の原因としては blowing 訓練の中止 ( 1 例), blowing manner の悪習 慣 (1 例), 術前の著しい軟口蓋の症痕化 (2 例) が考 えられた。

考 察: blowing ratio に上る経過追跡によって，各 各の症例の閉鎖機能の経過を明らかにすることができ た. 術後半月〜 3 カ月, 平均 1 カ月半は, 閉鎤機能の自 然回復の期間ということがでさよう.したがって術後 1 カ月半を経過しても閉鎖機能が改善されていない場合 は，集中的な blowing 訓練が必要となる，また，訓練 によって閉鎖機能が改善されてもただちに中止せず，乙 ばらく訓練を継続することが自然悪化を予防することに つながる。

今後はさらに多くの症例で, 術式や口蓋裂のタイプ, 年齢などと術後の blowing ratio の改善カーブとの関 連を検討していきたいと考穴ている。

\section{文 献:}

1）相野田紀子, 他 : 口蓋裂症例の鼻咽腔閉鎖機能簡易 評価法としての Blowing Ratio の利用. 音声言語 医学, $19: 261-266,1978$.

2）中田幸代 : 口蓋裂患者の言語障害と言語治療に関す る研究. 口病誌, $26: 592-615,1959$. 
質 問 : 都養育院病院・福迫陽子 blowing ratio の 改善とspeech (開鼻声) の変化は, どのような関係であ ったか.

blowing 訓練の内容はどういうものか. また， blowing 訓練の意義についてどのように拈考えか.

応 答 : 金沢医大・相野田紀子 術前, 構音の悪習慣
があれば両者に関連ないが，その他の場合は blowing ratio の改善に伴って speech も改善された.

soft blowing 1 日30分にして拈り，改善過程は個人 差がある。また，もうしばらく（どのくらいの期間かは わからないが) 訓練を継続すれば， blowing ratio の悪 化は防止できただろう.

63. 軽度の鼻咽腔閉鎖不全症例の取り扱いについて

神戸大学耳鼻科 木村 照

はじめに：口蓋裂の術後, 裂はきれいに整復されてい ても，軽度の鼻咽腔閉鎖不全を残すことがある。また， 口蓋裂はなくても軽度の鼻咽腔閉鎖不全を有する症例も みられる. いずれも開鼻声を有するとき, 手術と言語治 療のからみあいにおいて問題が出てくる. 軽度の鼻咽腔 閉鎖不全の取り扱い問題は，手術と言語治療の接点にあ ると考える.

自験例10例の内容 : 10 例 (男 2 例, 女 8 例, 3 歳 1 力 月〜 19歳) は口蓋裂術後 7 例, 口蓋裂を伴わない開鼻声 3 例 (非口蓋裂, 軟口蓋麻癘, 脳性麻痺 各 1 例) であ る. 8 例は手術を受けて扣り, 術後 4 力月から 6 年を経 過していた.

第 1 例は咽頭弁手術後も軽度の開鼻声を残したので, 両側小咽頭弁手術を行い, 音声は改善した。第 2 例は口 蓋形成術後, ごく軽い開鼻声を認めるものの, 開鼻声の 程度は変動し, 日常ほとんど気にならない程度である. 第 3 例は過去 2 回の手術後, 開鼻声と異常構音が続き, 咽頭弁手術を実施し，音声は少し改善した．第 4 例は口 蓋形成術後, 気にならない程度の開鼻声を認めるが, 再 手術はみあわせている. 第 5 例は口蓋形成術後, 開鼻声 は $(+)(一)$ が変動し, 再手術にふみきれないでいる. 第 6 例は口蓋形成術後, 開鼻声は変動したが, 鼻咽腔閉鎖 不全がはっきりしたので咽頭弁手術を行い, 音声は改善 した. 第 7 例は 3 歳の術後症例で，鼻咽腔閉鎖機能には 不安があるが，音声は良好であるため，観察を続けてい る. 第 8 例 (非口蓋裂) は 2 度の手術により音声は改善 した. 第 9 例 (軟口蓋麻痺) は軽度の開鼻声は認める が，異常構音を伴わないので，咽頭弁手術を実施するか どうかは，STの評価によって決定したい，第10例（脳 性麻痺）は, 呐頭弁手術によって開鼻声は解消した.
10例中の 9 例は軽度の開鼻声を示したが，異常構音は 2 例, 開鼻声の変動を 3 例に認めた。 5 例には鼻咽腔閉 鎖㙨能改善のために新たに手術を行ったのである.

軽度の毫咽腔閉鎖不全の特徽：(1)blowing は完全にで きる. (2)gag reflex の鼻咽腔閉鎖は完全である. (3)発 声時の鼻咽腔閉鎖不全は fiberscope で確認できる. (4) 構音の練習効果は大である. (5)異常構音は伴わないこと が多い. (6)単音はきれいに出るが，会話では軽度の開鼻 声を残す．７日によって開鼻声程度が変動する（カゼを ひいて鼻閉塞をきたすよらなときに開鼻声は減少するな どの例). 8人によって開鼻声の評価が異なる. 以上の ような状況が観察された。

重咽腔閉鎖不全の改善手術 : 咽頭弁手術と両側小咽頭 弁手術. 第 1 回目の改善手術は咽頭弁手術, 第 2 回目は 両側小咽頭弁手術を行っている．次第に鼻咽腔を狭くし ていけば，鼻閉塞をきたすが，今回の10例については患 者は鼻閉塞を訴えていない.

取扱いの要点：(1)早く再手術にもっていくべきか, 継 続して言語治療を行らべきか, 症例に応じて S T と医師 の意見交換を要した. (2) 2 例では軽度の開鼻声はその人 の個性の範疇でとらえてもよいように思われた. (3)手術 の動機は S T 側が音声改善の必要を認め, 手術に期待を かけるときに生まれた。ここでは手術適応よりも手術動 機の問題が重要であるといえた.

質 問: 愛院大・渡辺 幸 手術か, speech aid か, 言語治療かは, S Tが決めるべきか, 医師が決めるか, どのようにしているか.

応答：神戸大・木村 照 手術の決定は医師がす る. 医師と S Tが言語評価をめぐって激しい論争をする ことが大切と思う. 
64. 鼻咽腔閉鎖機能が限界值と考えられた子どもの言語訓練成績について

\author{
京都大学耳鼻咽喉科 川野 通夫, 萩尾 藤江, 条沢二三子 \\ 京都大学形成外科 一色 信彦
}

初診時に明らかに少量の発声時経鼻呼気漏出, 開鼻声 や構音異常, また視診上の異常（たとえば軟口蓋や咽頭 侧壁の運動性，軟口蓋の長さ，軟口蓋咽頭後壁間距離な ぞの異常) が認められた子どもたち 6 名について, 鼻咽 腔閉鎖機能限界値と診断し，手術はしないで言語訓練を 実施した.

対象は口蓋㤠術後 1 名, 粘膜下口蓋裂 2 名, 軟口蓋裂 1 名, 先天性鼻咽腔閉鎖機能不全 2 名の計 6 名で, 初診 時の年齢は 2 歳から 7 歳までだった。

構音について, 初診時の構音は多数の子音の省略を示 すむのが多く, 症例 6 のみは [p, s, J]音のみに異常が 認められた。

知能は, WISC, WIPPSI, Binet の 3 種類の検査を用 いたが，症例 1 は IQ57 (WIP-PSI), 4 は38.6 (Binet) と低く, 他は正常だった.このうち症例 1 は子どもの発 達にとってかなり不利な条件で㕕てられてきたもので, 潜在的能力はもっと高い可能性がある.

これら 6 例について言語訓練を実施した．訓練の内容 は, (1)呼気を口から出したり,口の中に溜めておいて [p] 音などの簡単な構音操作を教えること, (2)[ga]のささ やき声から次第に [ka] に誘導するような漸次接近法, (3)訓練者が正しい音をいって閆かせる聴覚的刺激と自己 の音声をテープレコーダーやビニールホースなどを用い てきかせるフィード・バック，(4)煩をふくらませたり， 舌尖をラララといって動かすよらな簡単な構音器官の訓 練の 4 項目に重点を扣いて実施した。いわゆる強く吹く 訓練はしていない。

結果は全例とも構音の改善が認められ, 症例 2 と 6 は 完全によくなったので終了, 症例 1 と 5 は定期的言語訓 練を終わって経過観察, 症例 3 女歌や短い文章では, 寸 べての音を正しく出すことができる，症例 4 は知能が低 く, 言語発達も遅れていて, 今後の訓練に困難が予想さ れるが， $[\mathrm{p}, \mathrm{t}, \mathrm{k}]$ は単語レベルで, [S] も音節として 出せるようになってきたので，言語訓練によって構音の 改善は可能だと考える. 鼻咽腔閉鎖機能については, 6 例中 5 例は構音時に呼気の鼻漏れが認められなくなり,
漏出が残っている症例 1 も初診時より減少している.

考 察：(1)鼻咽腔閉鎖機能が限界值と診断されたもの に，手術に先行して短期間言語訓練を試みることは有効 である.

(2)言語訓練で改善するかどらかの判断は軽く吹く訓練 から [p] 音を教えてみて 2 カ月以内に音節として正し く出てくれば予後がよいと思われる.

(3)指導法として，聴覚的な刺激などとともに，漸次接 近法などにより，正しい構音操作を教えることが重要だ と考える.

(4)訓練を終了した 4 例は先天性鼻咽腔閉鎖機 能 不全 2 , 粘膜下口蓋裂 1 ， 口蓋裂術後 1 であったが，これだ けでどの障害がな扬りやいと決めることはできない。

(5)症例 1 のよらに軟口蓋咽頭後壁間距離がながく, か つ軟口蓋の動きもそれ程よくないものは增龄に伴い鼻咽 腔閉鎖不全を将来示す可能性があると考劣る。

結 論 : 咽頭弁形成術か言語訓練かの適応決定は, 種 種の検查結果に基ついて行われるが，なお困難なことが 多く, その一診断法として治療的診断法 (diagnosis ex juvantibus）が有効なことがある.

質 問 : 金沢大・鈴木重忠 鼻咽腔閉鎖機能限界値判 定の具体的な方法は.

応 答: 京大・一色信彦 限界值は空気力学的検査の 可能な例では, 50dyne $\mathrm{sec} / \mathrm{cm}^{5}$ あたりを限界値として いるわけであるが，こういった検査がでさない例では， nasality や破裂音, 摩擦音を発声させその印象, その 证みが時に変化するかどうか (consistency)などについ て総合判断し, 限界值とする. 限界值を一元的に定義す る事はできない.

質 問: 愛院大・渡辺 幸手術をするか, speech aid か言語治療かは, ST が決めるのか, あるいは医師 が決めるのかどのようにしているか.

応答：京大・一色信彦 手術の適応は S T と医師が 相談して決める. 徐々に言語治療をしてもらら症例がる えているょうに思う。 


\title{
65. 集中的言語訓練を行った口蓋裂児の 1 症例について
}

\author{
京都大学耳鼻咽喉科 条沢二三子, 川野 通夫, 萩尾 藤江 \\ 京都大学形成外科 一色 信彦
}

3 年以上にわたって, ことばの教室で言語訓練を受け たが構音改善がみられず，当科を受診した10歳の左側完 全口蓋裂男児について，宿泊による言語訓練（I 期 ; 昭 和53年 7 月 $21 \sim 30$ 日, II 期; 昭和53年 8 月 $9 \sim 22$ 日, 延 べ24日間， 1 日約 2 時間）を実施した.

初診時: 構音は母音と $[\mathrm{j}, \mathrm{n}]$ 以外は注とんどが声門破 裂音と歪み音であった $\left(\left[s, k, t, \int, t \int, k j ~ p\right]\right.$ は声門破 裂音, $[\mathrm{g}, \mathrm{b}, \mathrm{dz}, \mathrm{r}]$ は鼻音化).

長期間言語が改善しなかった原因は, (1)構音時の呼気 の鼻漏れ（口腔内圧は 0 で pneumo-tachograph の測定 はできなかった), (2)構音器官の運動のにぶさ(舌 運動 の悪さ等) にあると思われる. また構音時の呼気の鼻漏 れの原因としては, (1)鼻咽腔閉鎖機能不全, (2)瘦孔（長 さ約 $5 \mathrm{~mm}$, 幅 $2 \mathrm{~mm}$ ) からの呼気の漏れ, (3)呼気を口 に流す要領がわからない，などが考兄られたが特定でき なかった。

目 的 : 試験的に短期間言語訓練を実施し, (1)構音改 善しない主要因が何であるのか，(2)短期間の合宿訓練の 構音改善への効果をさぐることであった.

訓練方法：(1)呼気を口に流し，口腔内圧を高めるため に，呼気を口腔内に溜める練習（イ，顂をふくらませる. 口, 軽く吹く), (2)漸次接近法拈よび発音定位法により 構音操作を教える（単音節から無意味意節単 語へと導 <).

結 果 : (1)訓練開始 3 日目で $[\mathrm{p}]$ 音の構音ができる ようになり，構音が改善しなかった主要因は，(1) [pa， $\mathrm{pi}, \mathrm{pu}]$ 構音時㾇孔からの $100 \mathrm{~m} l / \mathrm{sec}$ 鼻腔漏出がある. (2)口唇や舌など構音器官の運動のにぶさ, にあることが わかった．そこで訓練は瘦孔に綿球をつめて行った，そ の結果 [p] 音連続構音時にわずかに鼻漏れがみられる 程度になり，鼻咽腔閉鎖機能はほぼ正常であることがわ かった. 訓練終了 1 力月後, 瘦孔閉鎖術を行った.

(2)構音は I 期終了時には $\left[\mathrm{p}, \mathrm{t}, \mathrm{k}, \int, \mathrm{s}, \mathrm{kj} \mathrm{t} \int\right]$ は単 語レベルまで改善したが， II 期開始時には $[\mathrm{p}, \mathrm{k}]$ 以外 は単語レベルで初診時の状態と変化なかった． II 期終了 時には [d]を除くほとんどの音が短い文章レベルまで 改善した. 訓練終了 1 力月半後（瘦孔閉鎖術後）の構音 は文章レベルで $[\mathrm{t}]$ がわずかに口蓋化傾向の歪 久音,

[d] が少し歪み音で連続構音で $[\mathrm{g}]$ になる他はほぼ改善 していた.

(3)(1)訓練を通して身辺生活の自立ができていないな ど, 行動上の問題が大きいことがわかった. (2) WISC 知 能検查の結果, IQ112 であったが学業成績は図画工作が 5 段階評価の 5 である他は，体育も含めて 3 㧊よびそれ 以下であった.

結 論：(1)軽度の鼻呐腔閉鎖不全や瘦孔による経鼻気 流であっても高度の構音の悪習慣をきす。

(2) 構音訓練を行うことにより長期間言語改善のなかっ た症例でも短期間に著明に改善しらる.

(3)言語訓練の結果として鼻咽腔閉鎖不全や瘻孔の影響 についての診断も可能となりうる.

(4)行動上の問題が今後の課題である.

66. 長期間言語訓練を受けた口蓋裂児の言語障害と発達上の問題 京都大学耳鼻咽喉科 萩尾 藤江, 川野 通夫, 夈沢二三子
京都大学形成外科 一色 信彦

他の機関で 3 年以上言語訓練を受けたが, 改善が得ら れないという理由で, 昭和 52 年 4 月〜 53 年 5 月まで当科 を受診した口蓋裂児20名について，その原因を検討した ところ，19名が明らかに，鼻咽腔閉鎖機能不全であり， 残り 1 名は限界値であった。また, 言語訓練について
は, 吹く練習, 言語音の弁別, 正しい音の模倣が中心 で, 構音操作については，ほとんど訓練を受けていなか った.

初診時の様子：(1)構音; 全員が開鼻声を伴う声門破裂 音, 口蓋化音, 歪み音等の構音の聴習慣がみられた。 
Vol. No.20 1, 1979. 1

(2) 構音器官の観察 ; 舌, 口唇を中心に構音器官の動き を観察したところ，20名中19名が口腔内に呼気を溜める 習慣がなく，口唇をきっちりと閉じ，ほほをらくらます ことができなかった．舌尖の動きについては，らどんを うまくすすれない者が20名中15名, 舌尖を上唇につける 動きが鈍い者が20名中13名みられた。

(3)WISC による知能検查; 全員に WISCによる知能 検査を実施した。比較のために，短期間（1年以内）に 構音改善がみられた口蓋裂児10名にも同検査を実施し た.

言語訓練：言語訓練に先き立って，鼻咽腔閉鎖機能不 全のある者には, 咽頭弁形成手術を実施し, 限界値の者 にはそのままで訓練を試みた。訓練は毎週 1 回の通院に よるものが中心であるが，遠隔地に住む者には年 2 回程 度の合宿と不定期の通院によって行った.

訓練内容は, (1)口腔内に呼気を溜める, (2)舌運動を中 心とする構音器官の運動促進, (3)言語等の弁別, (4)漸次 接近法による構音操作, 以上が中心であった.

結 果 : 18名について, 構音の著明な改善をみた. 訓 練期間は $5 〜 13$ 月であった. 遠隔地在住の者も合宿と 通院による親の指導で改善したが，軽度発達遅滞のある 者 2 名 $(\mathrm{IQ}=64,59)$ は，遠隔地に住んでいたため，上 記の方法のみでは改善がむずかしく，単語レベルでの改 善にとどまっている.

発達については，WISC による知能検査では，長期治 療群の平均 $I Q=105.4$, 短期改善群の平均 $I Q=104.7$, 同検查の言語性検査では, 長期治療群の中に, 一般理解 のみが著しく劣る特定のパターンを示す者が，20名中18
75-75

名, 短期改善群では10名中 2 名みられた．言語性検査の 下位検査項目 5 つを両群それぞれ比較してみると, 長期 治療群は短期改善群に比べて, 一般理解のみが, $\mathrm{p}=0.01$ のときに有意に差が出たところから，長期に言語訓練を 受けた者は，一般理解が劣る傾向があるといえよう。

また長期治療群のうち，3名について, 構音改善半年 後に同検査をしたところ，同様のパターンを示した.

結 論：(1)長期間の言語訓練で効果がなかった子ども であっても, 鼻咽腔閉鎖機能の改善後半年〜 1 年の練習 で構音は改善する.

(2)長期間効果のない言語訓練を続けた子どもは，WIS Cによる知能検査の言語性検査で特殊なパターンを示 与.

(3) 知能パターンの特殊性は, 長期間の訓練が原因かど らかは明らかでない。

(4)この知能パターンの特殊性は, 構音改善後も半年位 では変化を示さない.

追 加 : 東京学芸大 - 石川清明 一般的理 解の低さ は, 口蓋裂児に限らず，伝達行動に問題を持つ子供に広 く認められる.

長期間の訓練という要因より，むしろ社会性の発達と 関連が強いと考光られる. 一般的理解は, 生活経験に対 する判断を求める内容なので, その面からの関連は考え られる。

プロフィールは, 構音の改善のみでなく伝達行動の全 般的な改善がみられるようになってから変化することを 多数経験している.

すでに発表した内容からであるが追加した. 


\section{第IX群 構 音（II）}

\section{7. 発音教育用口腔立体模型について}

\section{東洋工業附属病院, 広島大学医学部 中野 豊道}

音声は「息」「音」「構音器官」の状態変化が複合さ れたものである. 従来, 構音器官の状態変化について は, 最も特徵あるところを, 口腔器官の横断図をもって 説明されてきた。しかし横断図は各音節の最も特徵ある 瞬間を 1 枚の図説で示すに過ぎず，生徒に十分な教育効 果をあげるものとはいえなかった.

それは構音動作すなわち, 上顎と舌, 軟口蓋と舌の形 状, 歯列と舌との相互関係, 舌の形状と, その動きにつ いては, すべてがロ腔の中での動きであって, 外部から 相手に見せられないために, 教師の努力にもかかわら ず，教示し難いものである，さらに聴覚障書児では，細 かい微妙な動きの説明が, 教師の川から相手の耳に十分 伝達されにくい.さりとて文章化して教示するといらこ とも微妙なことなので，十分な表現ができるものではな いだけに、こうした細やかなニュアンスに富さ構音動作 は，健聴児に教える以上に大きな困難が横たわっている といっても過言ではない.このように口腔内での構音動 作を, 目に見える形として, 立体的な口腔器官の模型で 表現するならば,より有効な教育効果を期待できると考 えて本研究にあたった。な技本研究は昭和46年から50年 にかけての第 1 期試験，52から53年にかけて第 2 期試験 の段階があった. 目下, 第 3 期の試験にあたっている.

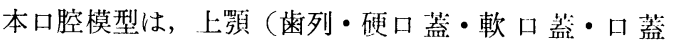
帆), 下顎 (歯列・下顎底), 舌の 3 部分からできてい る.な括の状態が観察されやすいように，上・下顎は 透明な合成樹脂で造られ，一方の側面は，内腔が見えや すいようにカットされている。また上・下顎は顎関節部 でジョイントにより連結され摺動抵抗を利用して，人の 会話時と同じように下顎はフリー・ストップで，必要な 開口位で固定できる．な括はゴム材の中に適切な空間 を配して，鉛板を変形板とし封入されて扣り，いずれの 方向にも自在に変形できるように造られ，必要な舌の形 状に変形した上で下顎に, 指示された位置, 高さに装着 できる、こうして雨列・硬口蓋・軟口蓋・口蓋帆との相 対的な位置関係を示すことができる.

このように本口腔模型は, 従来の横断図の図説より,
態を明示し，かつ教師と生徒の間に「語らい」を与え興 味をよび起こして有効な教育効果を与えることができ る.

本模型は上・下顎の開閉， $1 \mathrm{~m}$ の高さからの落下テス ト，日光暴露試験に打いても，一応何ら支障をきたさな かった. しかし舌の変形板である鉛板は，「いたずら」 的に同一個所を同一方向に折り曲げる動作を繰り返すと 折損する.したがってこうした「いたずら」を避けしめ て，通常の使用に対しては十分使用に耐える.

また本模型を全国の98校の，ろら学校に配布して14項 目の設問に答光てもらったところ，92\%の 90 校から解答 を寄せられた。本模型の外形，色調，人体模型としての 嫌悪感, 象徵性の可否, 舌の色調, 操作性, 舌の着脱性, 歯列の表現性などについて，だいたい70～80\%の有効性 が認められた。教材としての有效性と年齢との相関性 は, 10 12歳, 教員羡成課程学生, $6 \sim 9$ 歳, 13〜15歳 の順に効果があることがわかった，教員養成課程学生に 有効なことは興味がある. また積極的な助言が33校から 寄せられ, 舌の形状, 大ささ, 軟口蓋・歯列の表現, 幼 小児のため下顎のみが動くとする動態表現などについて 寄せられた。目下第 3 次の試験に颃いて，これらを参考 に入れて，よりよいものとすべく努力しつつあり，また 健聴者の外国語教育の教材としての有効性についても, さらに検討中である。

質 問：東大・桐谷 滋 ろら学校などでの使用には 直接関係はしないと思うが，一般的には舌根部や呐頭腔 の構造も示せると興味深いと考える. この部分の作成に ついてご経験なら，考えを教えて頂きたい。

応答：東洋工業付属病院（広大）・中野豊道 咽頭 後面, 舌根部の表現に今一つの工夫が必要であること は, 当然感じている. 演者は軟口蓋, 口蓋帆の表現にも 努力している，そこまでは改善策を行いつつあるが，舌 根部の後面の形状までは, 教育の現場で教示できるもの ではなく，やや複雑化してくるのではないかと思う．ま ずはどのようにアプローチすべきか，どの辺りまでの妥 協が必要かと考虑中である. より実際的に, 確かな形のあるものとして構音動作の状 
68. 音声言語における変動性, その解釈と臨床的意義

\author{
九州がんセンター 江口 実美 \\ 福岡大学 曾田 豊二
}

難聴者の音声言語の異常性は一定のパタンがなく, バ ラッキが大きく, その程度は難聴の程度と関連性がある ことを報告してきた．このような異常性は, 聴覚を経由 した自己調整機構の不全によるものとされている.

一般に生体の生理心理機能は恒常不変でなくfeedback control をらけて, 正常変動範囲の中で目的にかなった正 しい活動を行って扔り, 音声言語機能も例外ではない。 ここに, 音声言語に和ける異常性の実態は, そのパタン のみによるのではなく, 変動性によっても一面をみるこ とができよう。

まず，正常成人に拈ける正常変動性を中权領域からの 運動命令のレベルと, 末端現象の音響分析パタンについ て証明した.

正常成人男子 5 名に口唇破裂音を含む検査 語「ラッ パ」を, 各人についてそれぞれ60回発語させ, 構音時の 口輪筋筋電四をスピン電極によって採取し，その原波型 と平均化積分波 (インテグレーター), 音声波とをXY 紙 上飞記録し，各測定点の経時時間を測定して頻度分布を みると, 筋活動開始からピークにいたる時間, 終了まで の時間, 終了から音声開始までの時間は正規分布を示し たが，筋活動開始から音声開始までの時間は正規分布を 示さなかった. 音声活動開始は口輪筋活動の長短, 強弱 に関係なく筋活動の終了と連動してなされていることが 証明される。

末端音響現象については, 正常成人男子 5 名各人に検 查語「パトエキウ」を 100 回発語させ, その語音のソナ グラム上から 5 母音の第 1 , 第 2 フォルマント中心周波 数を測定し，それぞれの 100 回のトライアルに和ける頻 度分布をみると，いずれも正規分布を示した。

このように, 正常な音声言語活動は筋活動の段階にお いても, 末端音響現象の段階に打いても, 多数回トライ アルを行って個体内変動をみると, 正規確率過程にした がって自己調整をうけていることが理解される.

そこで, 変動性の指標として, その頻度分布に特ける 個体内標準偏差を求めてこれにあてて, その年秢的発達 を $3 \sim 13$ 歳, 成人, 各群 5 名, 計70名について各母音を
含む検査語を各 5 回発語させ, その第 1 , 第 2 フォルマ ント中心周波数の 5 回のトライアルに执ける值の標準偏 差を求めてみると, 3 歳では大きな変動を示し, 年齢と ともに減少して，11〜13歳で成人の示す変動と同程度の 変動性を示すことが示された，すなわち，正常人の正常 変動性は年踰とともに発達することが示されている.

このように, 音声言語障害の実態, 程度, 経過などを 明らかにするには，異常パタンを求めるだけでなく，変 動性をみることによって異常性の一面をみることができ ると考觉られる。

質 問: 久留米大・平野 実 ある人が同じことばを 絽り返して発する際に, 繰り返し毎に起こる母音フォル マント周波数の変動と, ある筋の活動状態の時間的経過 の变動とを, 同じょカニズムで説明してょいのであろら か. 大変疑問に思らがいかが。

忘 答: 九州がんセンター・江口実美 構音運動にお ける timing behavior は精神疾患とか, 特に意図して 特異な構音を行う場合は問題が別であるが，正常人が正 常な様式で categorical articulation を行う場合では, ある正常変動範囲の中に落ちるので, 変動性測定は可能 と考えている.

質 問 : 東大・桐谷 滋 対象が正規性の変動を示す ことと, 自己回帰型の調節機能を有することとは, 直接 には対応しないと考劣る。このためには，より具体的な モデルが必要になると考学るが，この点につきご説明い ただきたい，

応 答 : 九州がんセンター・江口実美 正常な生理機 能は同一個体内で頻回測定を行うと, 正規分布を示すこ とは多くの機能で証明されて打りこれは，feedback self control と関連されて証明されている.

追 加: 東大・広瀬 䜿 生体現象拈よびその効果 （たとえば, 音声シグナル）の変動性には，種々の要因 が関係し, 極端な場合は生理現象以外の要素が関与する 場合がありらるので, データの解积を画一的な観点から 行うことには問題があると考える. 
69. 発音運動と筋電図パタンの相関解析

一口蓋帆の調音運動一

\author{
電気通信大学 米本 清 \\ 東京大学医学部 桐谷滋, 広瀬肇
}

はじめに: 調音運動の研究では, 中枢から音声器官に 与兄られる運動制御信号のパタンと, この指令により運 動を生ずる音声器官の運動特性とをあわせて解析してい く必要がある.この種の目的のためには，われわれは， X線マイクロビーム装置による調音運動の観測と, 筋電 四の同時記録を行ら方式を確立した、本研究では，口蓋 帆の調音運動と, 口蓋帆挙筋の筋電図を同時記録して対 応関係を解析した。

観測方法 : 日本語では鼻音として音節頭の鼻子音 $/ \mathrm{m} /$ 音節末の撥音/ $\mathrm{N} /$ 抢よびこの両者の連続した場 合の二重 子音の三種の型を考劣ることができる、これらの発音を 比較するために /bemee/, /beN'ee/, /beNmee/ などを 検査語とした。検査語は，キャリア文「とれは一で す」のなかで発音され, 被験者は, 東京方言の成人男子 1 名である.

口蓋帆の運動は, 薄い細長い紙片の先端に直 径 約 3 $\mathrm{mm}$ の鉛ペレットを接着して鼻孔より挿入し，ペレット が口蓋帆上面の先端付近にとどまるようにして，その動 きをX線マイクロビームにより記録した，筋電図は， hooked-wire electrode を腔内より插入し，ペレット 観測の 1 フレームごとのタイミングパルスとともに，い ったんデータレコーダに記録した. 後に, 計算機に, 8 $\mathrm{kHz}$ サンプリングで入力し, 絶対值をとってフレーム ごとに平均した值を記録した。

観測結果 : 口蓋帆の上下運動が，筋活動を入力とする 線型二次系の応答として実現されるものと近似し，その 特性を解析した。すなわち, フレーム時刻における，口 蓋帆上ペレットの $\mathrm{y}$ 座標值を $\mathrm{yi}$ とする時, EMG 信号の 值が次式で与えられるとする.

$$
\widehat{\mathrm{EMGi}}=\mathrm{Co}+\mathrm{C}_{1} \cdot \mathrm{yi}+\mathrm{C}_{2} \cdot \dot{\mathrm{yi}}+\mathrm{C}_{3} \cdot \ddot{\mathrm{yi}}
$$

各フレーム時刻での速度, 加速度の值は, 実測座標值 の時間曲線を多項式近似して計算する. この值と, 実測 EMG の差の 2 乗和

$$
\mathrm{Err}=\sum_{i}(\mathrm{EMGi}-\widehat{\mathrm{EMGi}})^{2}
$$

を最小とするような係数 $\mathrm{Co}, \mathrm{C}_{1}, \mathrm{C}_{2}, \mathrm{C}_{3}$ の值を求めた. その結果では, 二次系の減衰定数は0.9 1.0で, 系が臨 界制動に近いことを示している. また，時定数は約 $70 \mathrm{~m}$ $\sec$ であり, この值は, 通常, 母音間のフォルマント変 移について考兄られている時定数の約 2 倍であった.

口蓋帆の運動パタンは, /bemee/では, 下降の速度に 比べて, 下降後の上昇の速度が小さく, 下降・上昇のパ タンは時間的に非対称である./beN'ee/では, 下降運動 は, /m/よりも長く継続して下降量が大きい。また，上 昇の速度も $/ \mathrm{m} /$ より大きく, 運動パタンは時間的に対称 に近い, /beNmee/では, 下降のピークに達した後, ほ ぼ定常的な状態が $/ \mathrm{m} /$ の閉鎖の開放付近まで続き，その 後明らかな上昇が開始される. 鼻音としての区間は $/ \mathrm{N} /$ より長いにもかかわらず，口蓋帆の下降量は/N/より小 さい.

上記の運動パタンに対応して EMG パタンでは, 以 下の特徽がみられた／N/では, ステップ的に変化する 筋活動のほぼ完全な抑制の区間が存在する. 口蓋帆の運 動は, この制御信号に対する平滑化された応答とみるこ とができる. $/ \mathrm{m} /$ では, 筋活動の抑制区間の幅が約 120 $\mathrm{msec}$ で, 二次茲の応答時間に比べて小さく, 運動パタ ンは, インパルス応答的な ballistic な運動とみられる。 このことは，運動パタンが時間的に非対称なことと傾向 が一致する。/ $\mathrm{Nm} /$ では, いったんほぼ完全な抑制を生 じた後, /m/の開放付近まで, 中間レベルの筋活動の区 間があらわれる.抑制の区間は/N/よりも短く、それに 続く中間レベルの活動により, 下降運動が途中で抑止さ

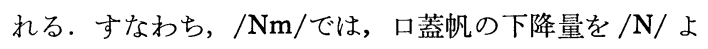
りは小さく保つための積極的制御が行われているものと 考えられる. 
70． 語音発音時の強さと構音点圧との関係

$$
\text { 足立学園 原 ケイ子 }
$$

九州大学耳鼻咽喉科 小宮山荘太郎, 広戸幾一郎, 笠 誠一, 川上 親仁

語音発声時の口腔咽頭内圧に関しては, すでに西田 （1963）が構音点圧，矢野（1963）が構音帯圧と呼び報 告しているが，いまだ一定の名称はない，著者らはこれ を仮に構音点圧と呼称することとする。

構音点圧は, 語音発声時の音声の強さ・高さあるいは 声門の状態などの影響をらけるが，いずれの研究も単に 構音点圧のみを測定したものである. そこで, 本研究で はまず音声の強さと構音点圧との関係を明らかにすべ く，検討を加えたので報告する.

研究方法 : 語音発声時の音声の強さの測定には, 騒音 計 (リオン社)と High Speed Level Recorder (B\&K 社）を接続し記録した。 また口唇・マイクロフォン間距 離は $20 \mathrm{~cm}$ とした，構音点圧の測定には，拡散型半導体 小型圧力変換器 (豊田工機) を使用し, 経鼻的に中咽頭 腔まで插入固定し記録した。

研究対象: 正常音声, 正常言語を有する20〜23歳男子 5 名と構音障害を有する 2 症例を被検者とした，被検者 の声の強さは, 騒音計を見せながら, 弱い声 (70dB 程 度), 中等度 $(80 \mathrm{~dB}$ 程度), 強い声 ( $90 \mathrm{~dB}$ 程度), とし, 検査語音を 10 20回発声させた。検查に用いた語音は， 破裂音 $\mathrm{p} \cdot \mathrm{b} \cdot \mathrm{k} \cdot \mathrm{g} \cdot \mathrm{t} \cdot \mathrm{d}$, 摩擦音 $\mathrm{s} ・ \mathrm{z}$ で, それぞれ $10 \sim 20$ 回発声させ, 発声時の音声の強さと構音点圧との 関係を二次元的に記録した.

研究結果 : 各検查語間に打いて音声の強さと構音点圧 との関係は, 強く発声された語音ほど, 構音点圧も上昇 した. 各検查語間の構音点圧を比較すると, $\mathrm{p} \cdot \mathrm{k} \cdot \mathrm{t} \cdot \mathrm{s}$ の順に構音点圧は上昇する. 特に中等度の強さの時にこ の傾向がみられた．弱い声 $(70 \mathrm{~dB}$ 程度) ・中等度 $(80 \mathrm{~dB}$ 程度) の強さの発声に扔いて, 有声子音 $\mathrm{b} ・ \mathrm{~g}$ では無声 子音 $\mathrm{p} ・ \mathrm{k}$ より構音点圧は低い. しかし, 同じ強さで発 声した $\mathrm{t} ・ \mathrm{~d} ・ \mathrm{~s} ・ \mathrm{z}$ については, その压に著明な差異が みられない。また, 強い声 ( $90 \mathrm{~dB}$ 程度) の発声でも有 声子音と無声子音との間に構音点圧の差異はみられなか った。

サ行構音障害例についてでは, 摩擦音 $\mathrm{s} \cdot \mathrm{z}$ 発声時の 構音点圧は, $\mathrm{k} ・ \mathrm{~g}$ と同じ程度の構音点圧を示す. また 有声子音・無声子音間に差異がみられない特徵を示し
た。 右唇顎口蓋裂の術後の症例について, この症例は, 術 後 speech aid を用いて言語訓練を行ってきたもので, 初診時, 発語明膫度は $10 \%$ 前後であったが, 訓練 3 年後 の現在では speech aid を用いなくても75\%の発語明瞭 度まで改善された. しかし, カ行・サ行の構音が正常と はい党ない状態である.この症例について現在の構音点 圧をみると， $\mathrm{s}$ 発声時に構音点圧が十分上昇しない。 た, $\mathrm{t} \cdot \mathrm{d}$ や $\mathrm{s} \cdot \mathrm{z}$ の発声時に, 無声子音より有声子音の 構音点圧が高いといら正常者の構音点圧の傾向とは逆の 現象がみられた。 また $\mathrm{k}$ 音発声時に構音点圧が異常に高 くなった.これは speech aid を用いなければ, 過矯正 を行っていることを示唆しているのではないかと思われ る。

以上，私たちは語音発声時の声の強さと，構音点圧を 測定し検討した. その結果, (1)一般に強く発声するほ ぞ, 構音点圧も上がる傾向を示す. (2)無声子音で $\mathrm{p} ・ \mathrm{k}$ は $\mathrm{t} ・ \mathrm{~s}$ 発声時より, また有声子音で $\mathrm{b} \cdot \mathrm{g}$ は $\mathrm{d} ・ \mathrm{z}$ 発声 時より構音点圧が低い傾向を示す. (3)弱い声 $(70 \mathrm{~dB}$ 程 度) や中等度 (80dB程度) の強さの発声で, 有声子音 $\mathrm{b} \cdot \mathrm{g}$ は無声子音 $\mathrm{p} ・ \mathrm{k}$ より構音点圧が低い傾向を示す。 強い声 (90dB程度) の発声では, 有声子音, 無声子音間 に差異はみられないといら結果を得た。ささらに, 構音障 害例にみられたように, この検査法は構音障害の程度の 把握, 構音訓練効果の判定などに応用できることが示唆 され, 臨床上, 有意義な検査法であると思われる。

追 加: 東大・広瀬 整 構音点圧という呼称は適当 でなく，単に声門上圧としてよいと考光る.

測定 (観察) 対象としては, ピーク值のみでなく, 圧 の立ち上がり，下りの経過（時間カーブ）などをみれ ばたとえば語音間の差がはっきり出ると思う.

追 加: 久留米大・平野 実 スピーチに関する生理 学的研究を行う場合, 対象とする語音 (音韻でる単語で も）はフレーム文の中に入れるのが原則である. utterance の初めと終わりは，その語音には直接関係のない， 非恒常的な筋活動の影響を受けるからである. 実験計画 を立てるときにご注意いただきたい． 


\title{
71. 麻痺性構音障害における発声発語器官の運動特性について
}

\author{
一共同運動パタンからの分析一
}

\author{
浜松医科大学脳神経外科聴能言語室 小島 義次 \\ 農協共済中伊豆リハビリテーション・センター＼cjkstart窪田 俊夫
}

麻疸性構音障害は，㺞下障害をしばしば伴うが，その 関連は，ほとんど未検討である．両者は，神経筇系の病 変による構音一摂食器官の運動障害に起因する. その運 動異常の特性を分析することにより，両障害の関連を探 る手がかりが得られると考兄られた。併せて，ファシリ テーション・テクニックとの知見の交流も期待された.

今回は, 共同運動とその分離といら観点から運動特性の 検出を試みた.

方 法 : 失語や著明な痴呆を除いて, 脳血管障害によ る構音障害患者21名に構音器官の非言語的運動 9 項目, 協調動作 4 項目, 㫶下（水のみテスト） 1 項目を丰施. さきの 9 項目では，A一できる，B一少し問題がある. C一できないの 3 段階に評価した。 この評価と別に, 要 求された動作以外に余分な動作を伴う時, 共同運動とし て記載した．交互運動は，5秒間の回数を測定した．協 調動作は 3 段階に，㫶下は 4 段階に得点化した.さら に，会話と音読から会話明瞭度を 5 段階に評価した。

結 果: 会話明瞭度は, 信頼性も考慮して, 1，2 $3 ， 4 \sim 5$ の 3 群に分けて，大まかな目安とした. 交互 運動は少数を除いて回数の低下が著明であり，その平均 値は, 会話明瞭度に対応した。

運動課題で「でさる」と判定された項目数と会話明瞭 度との関係，「できる」項目のうち分離運動が可能な項 目数と明瞭度との関係は, いずれもスピアマンの順位相 関係数が $1 \%$ で有意であった. 共同運動発現項目数と明 瞭度との関係をみると, 明瞭度 2 以下で共同 運動が多 い. 運動能力との関係では，ごく運動が制限された状態 から, 共同運動を伴う随意運動へ, さらに分離された運 動へといら推移が示唆された. そこで, 発現した共同運 動のタイプを項目ごとに整理してみると, 被験者間に高 い共通性のあることがわかった.『声の on-off 反復』で は「頭部が前後に動く」7例，「しぼり出すような声の 増強」4例で，この項目で発現した共同運動の73\%を占 めた.『口唇を突き出しひく交互運動』では「下顎が上
下に動く」9 例で $82 \%$ 占めた. 『舌の突出後退交互運 動』では「下顎が上下に動く」12例，「口唇を突き出し ひく」7例で95\%を占めた，以上，その例を示した。な お，1つの項目で 2 つ共同運動を同時に示す者もあ り, おの拈の共同運動として集計した.

協調動作得点と分離運動可能項目数, 協調動作得点之 会話明瞭度は，おの打の $1 \%$ で有意な相関があった。協 調動作得点が中位レベルの者では, 共同運動発現項目数 の多いことが注目された。

㫶下得点と分離運動可能項目数との相関は $5 \%$ で有意 であった. 分離運動可能項目数に比べて與虍下得点の高い 数例については, 共同運動が多く発現していることがわ かった. 舆下得点と会話明膫度との間には有意な相関が 無かった. 四燕下動作で共同運動が占めるいっそう積極的 な役割を示唆するものと考えられた.

結 論：(1)各項目で発現した共闹運動のタイプは, 被 験者間に高い共通性があり，共同運動パターンとしてと らえ得ると考えられた。(2)分離運動可能項目数が多い ほど会話明瞭度が良い。(3)最も重度の症例では運動自体 を随意に行らことが困難であり, 捙動能力がある程度回 復している者では, 共同運動が多く発現している.さら に運動能力の高い者では, 分離運動可能な項目数が多か った. (4)会話明瞭度 2 以下で共同運動が多かった（5)協 調動作得点は, 分離運動可能項目数が多いほど高かっ た. 協調動作と会話明瞭も有意な相関を示した. 協調動 作得点が中位の者では, 共同運動が多い.(6)分離運動可 能項目数が多いほど曣下得点は高い傾向があった. 分離 運動可能項目数の割に㫶下得点の高い者では, 共同運動 が多く発現している. 㫶下得点と会話明瞭度には有意な 相関が無かった。曼下動作での共同運動の関与が考えら れた.

以上，共同運動とその分離という観点を軸とした運動 能力の段階づけが考えられた. 


\title{
72. 小脳性言語の解析
}

\author{
鹿児島大学医学部第 3 内科 浜田 陸三, 井形 昭弘 \\ 鹿児島大学工学部電子工学科 南竹 力
}

小脳珄言語の解析は，従来熟練した験者が被験者の発 声を聞いて，各要素に分解した上でなされており，主観 に頼る面も多かった。これに対しわれわれは，小脳性言 語の客観的評価法に関し検討を行ってきたので，これを 報告する。一方，この手法を用いて，小脳性言語の構造 を明らかにする目的で，因子分析を試み，さらに小脳性 言語を判別するには，ぞのような要素を重視すべきかを 明らかにするために，判別分析を行ったので報告する.

方 法: 対象は水俣病認定患者, 水俣病認定棄却者, 脊䯣小脳変性症患者拈よび正常健常者とした.

解析の対象とした言語は，単音節の繰り返し発声およ び信号者に対する床答発声である，単音節の繰り返し発 声は，「タ，タ，、, タ」と「夕」音をできるだけ均一 に，任意の速さで繰り返し発声させたものを用い，応答 発声は定常間隔（遅・速）拈よび，ランダム間隔の信号 者をイヤホンを通じて被験者に聞かせ，これに応じて 「タ」音を発声させた。音声㧍よび，信号音を $2 \mathrm{ch}$ 磁気テ 一プに記録し，これを $\mathrm{A}-\mathrm{D}$ 変換して音声間隔（応答発 声の場合は反応時間), amplitude, build up time, 音声 幅を計測した．次いで得られた粗データから，オンライ ン下で 2 回毎の平均値に対する変動の比を連続して計算 した.これらのデータを基に, 各群毎の平均値, 標準偏 差を求め比較する一方，因子分析および判別分析を行っ た. 因子分析はBMD 03M を用いて直交解を求めた後, バリマックス回転を行い，さらに各症例につき因子評点 を求めた．判別分析は，水俣病認定患者15名および棄却 者16名を対象に BMD 04M を用いて行った.

結 果: 自発発声酒しては音声間隔, amplitude, build up time, 音声幅のいずれにおいても, 小脳疾患群 は正常群に比べ有意に大きな变動を示し, 小脳性言語に おけるリズムの乱れが示された．応答発声に関しても同 様に, 反応時間, amplitude, 音声幅で有意差が認められ た.
因子分析の結果，第 1 因子拈よび，第 2 因子はそれぞ れ応答発声, 自発発声においていずれも amplitude, 音 声幅に関して平均值, SD ともに高い因子負荷量を示し, 発声に打ける量的因子と解喽された。

第 3 因子は 3 種の信号者に対する応答発声での反応時 間に高い因子負荷量を示し，反応時間の因子と解釈され た.第 4 因子および第 5 因子はそれぞれ低頻度, 高頻度 の定常関隔信号音に対する応答発声に関してamplitude, 音声幅に高い因子負荷を示した.

一方, 判別分析の結果, 31 例中 29 例を正しく判別し, 93.5\%の正診率を得た. 䛇判別をした 2 例はいずれも非 水俣病を水俣病としたものである. 判別係数の高い項目 は, 自発発声の音声幅, 音声間隔および，応答発声の amplitude であった.

考 察: 単音節の繰り返し発声は, 正常言語において も変動が大きいために，得られた粗データをそのまま比 較するだけでは，生理的変動と失調性言語を識別するこ とは困難である.しかし，適切なデータ処理によりこれ らを識別し得ることが示唆された。

一方, 因子分析は複雑な要素の中から少数個の内在す る因子を抽出して，積極的に解釈しようとするものであ るが，これにより小脳性言語の構造が示され，小脳性言 語に打けるリズムの乱れを，量的因子と時間的因子とに 分解し得た.さらに自発発声と応答発声の因子が明らか にされたことは今後, 各種小脳性疾患に打ける症候の検 討に応用乙得ると思われる。

判別分析の結果は，小脳性言語の評価に定量的な尺度 を与光るもので，小脳性疾患の診断，経過観察，治療効 果の判定等に有用と思われる.

追 加：九州がんセンター・江口実美 構音運動機能 の小脳性疾患における変動性についても調べていただき たい。 
73. 麻痺性構音障害患者の話しことばに関する評価項目の判別分析に よる検討

麻痺性構音障害患者の話しことばは, 原疾患により異 なった特徵を示すことが知られている. Darley ら こうした話しことばの特徵を捉えるため, 38 の評価項目 を設定して患者の発話を等現間隔法により評価し, 疾患 群每に各項目の平均得点を求めた. その結果, 各群の平 均的なことばの特徵が抽出されることが明らかとなっ た. 広瀬 ${ }^{2}$ および筆者 ${ }^{3 \sim 5)} ら$ は同様の方法を用いて日本 語に抢ける話しことばの特徵抽出を行った結果, やはり 各群に特有の平均的特徵が抽出され, この方法が話しこ とばの特徵抽出に有効なことが明らかとなった.

しかしながら，個々の患者の話しことばの特徵は必ず しも一様ではなく, 個人差がみられる.このため, 群の 平均的特徵に関して検討するだけでなく, 群と群との分 離の程度についても検討する必要がある.このような見 地から, 麻痺性構音障害 4 群の話しことばの評価結果に 基づいて判別分析を行ったので, その結果について報告 する.

方 法: 対象は, 神経学的に診断の確定した小脳疾患 (ATAXIA), 仮性球麻盘 (PBP) 各20例, 筋萎縮性側索 硬化症 (ALS) 30例, ペーキンソン病 (PKN) 34例, 計 104例であった。

音声資料は, 録音された $3 \sim 4$ 分半の会話, 復唱, 朗 読などを用いた。1 名の医師拉よび 7 名の言語治療士が 明瞭度, 異常度を除く37項目 ${ }^{325}$ に関して等現間隔 法に よる 4 段階評価を行った. 個々の患者の各項目の評価得 点は, 8 名の評価者の平均值で与えた。いま，37項目の 得点からなる $\mathrm{i}$ 群, $\mathrm{j}$ 群の平均得点べクトルをそれぞ れ $\mu^{i}, \mu^{j}$, 級内共分散行列を $\Sigma$ とすると， $\mathrm{i}$ 群， $\mathrm{j}$ 群の重心間のマハラノビス距離 Dは, 次式で与えられる.

$$
D^{2}=\left(\mu^{i}-\mu^{j}\right) \Sigma^{-1}\left(\mu^{i}-\mu^{j}\right)
$$

結 果：37項目の得点に基づいて求めた群間のマハラ ノビス距離は, 次の通りであった. ATAXIA と他の 3 群との距離は、注汸6ないし7であり, PKN と PBP, PKN とALS 間はともに約 4.5, また, 重心間の距離 が最も近い PBP と ALS でも, その距離は 3.5 であっ

$\begin{array}{rll}\text { 東京都老人総合研究所 } & \text { 辰巳 } & \text { 格 } \\ \text { 東京都養育院付属病院 } & \text { 福迫 } & \text { 陽子, 物井 } \text { 寿子 } \\ \text { 北里大学病院 } & \text { 小林 } & \text { 範子, 熊井 和子 } \\ \text { 虎の門病院分院 } & \text { 藤林真理子 } \\ \text { 東京大学医学部 } & \text { 廣瀬 肇 } & \end{array}$

た.この結果は，37個の全評価項目を用いれば， 4 群の 分離の程度がかなり高いことを示すものであり，この方 法により群の平均的特徵のみならず, 個々の患者の特徵 も抽出されていることが示唆される. 群間距離の大きさ から推測されるように, 判別結果は良好で 104 例中99例 が正しく判別された. 誤判別の 5 例中 ATAXIA 1 例が PKN に, PBP 2 例が ALS に, 2 例の ALS が PBP とPKN に誤判別された. PBP と ALS の confusion は50例中 3 例と少なく, 臨床上の印象とは異なるが, 症 例数が少ないため, さらに検討を要する.

次に，判別に貢献する項目を見い出すため，まず項目 数を 1 として群間距離を最大にする項目を選び,ささらに これと残りの項目を組み合わせ，やはり群間距離を最大 とする 2 項目の組み合わせを選んだ. この操作を群間距 離が 3 を越えるまで続け, 得られた項目の組を判別に貢 献する項目とした．ATAXIA と他の 3 群との判別には ともに「構音の non-systematic なくずれ」, PBP-ALS では「高さが一様」「開鼻声」など13項目，PBP-PKNで は「子音の省略・置換」「大きさの変動」「粗䊁声」,ALSPKN では「開鼻声」「速さ不規則」などが判別に貢 献 した. 以上の項目には, 特定の群だけに高得点の項目と 各群で共通に高得点の項目とがある ${ }^{3 \sim 5}$ が，後者におい ても異常の程度に差があれば判別に貢献する.

終わりに本研究に協力された北里大学の小川展子氏, 中央 鉄道病院の白石幸枝氏, 自治医科大学の乘真理子氏, 有益 な助言を頂いた横浜国立大学の笹沼澄子先生に感謝する.

\section{文 献}

1) Darley, F. L., et al. : JSHR 12,:246-269, 1969.

2）広瀬 肇: 中枢神経障害へのアプローチ（切替一郎

編). 金原出版, pp. 214-232, 1973.

3）小林範子・他: 聴覚言語障害, 5:63-68, 1976.

4) 藤林鱼理子・他 : 音声言語医学, $18: 101-109,1977$.

5）熊井和子・他 : 音声言語医学, $19: 20-22,1978$.

質 問：虎の門病院・船井洋光 各項目間の独立性は 
どのように判定したか.

判別関数を使用する場合, 各級数は正規分布しなけれ ばいけないと考えるがどうか。

応 答 : 東京都老人総合研究所 - 辰巳 格 基本的に は各評価項目は，独立となるように配虑して作成してあ る。しかし，「開鼻声」および「子音のひずみがある」
などの項目のように必ずしも独立ではないものもある.

得点の分布が特定の分布型である必要はない. しかし 分布が正規型でなくても少なくとも単峰性であれば, 結 果の解釈などに好都合である（本実験での分布型は, 被 験者数が少ないため正規型ではないが，大多数の場合単 峰性であった).

74. 時閒制限下における発語成功率について

喚語能力の検出とその方法の開発を目的として，時間 制限下に打ける発語成功率を検した.

材料, 方法 : 失語症・小脳性疾患・吃音・正常者対称 群に対する結果は予稿集に述べたが，今回絵刺激に加兄 $\tau$, 平仮名文字刺激, 漢字 - 片仮名文字刺激 3 群を刺激 材料とし ( 1 単語あたり 2.7 音節), 特に失語症者の結果 を正常者と対照して検討した.

対 象 : 神奈川リハビリテーション病院にて，脳血管 障害に起因する失語症と診断された 4 例（男 3 名，女 1 名), 年㱓 $26 \sim 58$ 歳, 発症後 $3 \sim 24$ カ月, タイプはすべ $\tau$ schvell の分類 I 群，小脳性疾患 1 名，女，56藏，発 症後 3 年, 吃音 1 名, 男, 18 歳, 対称群として正常者 3 名 (男 2 名, 女 1 名), 年齢23 27歳.

使用器材 : プロジェクター (ROTARY CABIN1000),

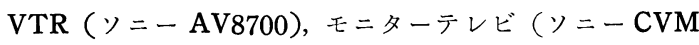
1800).

方 法: 100 単語 3 群を0.5, 1.0, 2.0, 4.0, 8.0, 16.0 秒の間隔で VTR に録画し, 被験者にあらかじめ絵刺激 に対する正答を教示した後, VTR を再生し, 呼称を求 めた．評価方法は，絵刺激による発語の場合，(1)正答の 音節数とほぼ一致すること. (2)音素の一致率が50\%以上 であること. (3)提示された絵刺激と意味的に同等である 時，(1)を満足すれば正答とした．文字刺激の場合は， 正確に正答を求めた.

結 果: 正常者 3 名の発語成功率平均値は, 平仮名文 字刺激の場合, 0.5 秒間隔提示 $89 \%, 1$ 秒間隔提示 100 $\%$, 漢字・片仮名文字刺激の場合, 0.5 秒間隔提示時 74 $\% ， 1$ 秒間隔提示時 $89 \% ， 2$ 秒間隔提示時 $95 \%$ であり, 絵刺激の場合， 0.5 秒間隔提示時 $60 \%, 1$ 秒間隔提示時 $95 \% ， 2$ 秒間隔提示時 $99 \%$ を示した.

失語症患者 4 名の発語成功率平均值は, 平仮名文字刺 激の場合， 1 秒間隔提示時 $42 \% ， 2$ 秒間隔提示時 $70 \%$, 最高成功率 $99 \%$ であった. 漢字・片仮名文字刺激の場

\section{神奈川リ八病院言語科 赤星俊}

合， 1 秒間隔提示時 $40 \% ， 2$ 秒間隔提示時 $58 \%$ で, 最高 成功率は $75 \%$ であった. 絵刺激の場合, 1 秒間隔提示時 $24 \% ， 2$ 秒間隔提示時 $47 \%$, 最高 $73 \%$ であった.

また，同一失語症患者に上記テストを 5 回，一定期間 を执いて繰り返し検したが，平仮名文字刺激では，0.5 秒間隔提示時の平均発語成功率 $56 \% ， 1$ 秒間隔提示時の 平均発語成功率 $94 \%$ ，漢字・片仮名文字刺激では 0.5 秒 間隔提示時の平均発語成功率 $36 \% ， 1$ 秒間隔提示時の平 均発語成功率 $84 \%$ であり, 絵刺激では 1 秒間隔提示時の 平均発語成功率 $12 \% ， 2$ 秒間隔提示時の平均発語成功率 は $57 \%$ であた。㧍の打の条件の異なる提示時間の平均 発語成功率の差は, $0.5 \%$ で有意であった.

まとめ・考察 : (1) 発語成功率は, 提示時間とともに 增加した.

(2) 正常者群の発語成功率は，時間とともに急激に 100 \%に近づくが, 失語症者群の発語成功率は, 時間とと もに緩徐に上昇し，その曲線は，群内で同じ傾向を示 した.

（3）失語症者群での, 高成績の順は, 平仮名文字刺激, 漢字・片仮名文字刺激, 絵刺激であったが, 正常者群 では，平仮名文字が高成績を示した。

(4) 同一失語症者に上記テストを繰り返し検した結果, 各時間制限条件下で，2つの異なる提示時間での発語 成功率の差が有意であった.

(5) この検査・材料は，喚語力検出に有効であることが 示唆された．今後さらに検討していく予定である.

質 問：金沢大・鈴木重忠 吃音ではどもりやすい音 と，そうでないものと大きな差がある２者の差をどの ように考慮したか。

応答: 神奈川リ八病院・赤星 俊 吃音のケース は，ブロックが主症状であったが，この検査は，全体的 に把握することを目的として招り，今後検討したい。 


\title{
75. 失語症状と脳病変部位について
}

\author{
虎の門病院 戸塚 元吉, 船井 洋光, 藤林真理子 \\ 東京都養育院付属病院 福迫 陽子 \\ 横浜国立大学, 東京都老人総合研究所 笹沼 澄子
}

大脳における言語機能の局在性を調べるために，失語 症患者の CT (computered tomography) 像によって, 病変の部位および範囲を調べた.

対 象: 脳血管障害によって左大脳半球に病巣を生 じ, 失語症となった患者 102 名である. 失語症の病型は Schuell の分類を準用して単純失語20 例, 感覚運動障害 を伴 5 失語 32 例, 非流暢な構音を伴ら失語 6 例, 浮動的 聴覚失認を伴 5 失語10例, 伝導失語 12 例, 全失語 6 例, 純 粋発語失行 2 例, その他の病型牤よび分類不能のもの 14 例に分けた. 発病より約 3 カ月経たものを対象とした.

研究方法：CT像について病変の範囲を計測し，この 值に基ついて脳の側面扣よび前面図に病変部位を投影し た図を作った，各病型別に投影図を重ね書きし，各病型 に特有な病変範囲を求めた。 さらにこれらの資料に基づ いて, 病変の範囲から病型を推定する計量診断を行っ た.この診断に最大尤度法を用いた.これらの一連の作 業にはマイクロ・コンピュータを使用した.

結 果: 全症例について病変の範囲を重ね書きする と, 前頭葉の前上部, 頭頂葉の上半部後頭葉の後半部お よび側頭葉の下半部を除く部分に広がっており, 特に中 大脳動脈に沿ら部分には多い重なりが見られた。単純失 語では病変の部位が散在し, 部位や範囲について共通な 特徵を見い出すことができなかった. 感覚運動障害失語 では前頭葉後下部に病変を持ったものが多く, 集積の高 い部分は32例中28例の病変が重なっていた. この部位が この病型の失語症の責任部位と考えられる. 非流暢構音 失語の病変は, 感覚運動失語の範囲に含まれていた。聴 覚失認失語ではシルビウス溝後部をはさむ部位に重なり がみられた。この範囲はいわゆる Wernicke 中枢を含 み, さらにやや上方に広がった範囲である，伝導失語は いずれも病変の範囲がせまく, シルビウス溝後端のやや 上方の限局した部分に，著しい重なりがみられた。 また この病巣は, 皮質より皮質下におよぶ深い軟化巣であっ
た. 全失語は病変の範囲が広いものが多かったが, 病変 部位には特徵的な重なりはみられなかった。

最大尤度法は

$$
\mathrm{L} \alpha=\pi_{i=1}^{k} \operatorname{Pi} \alpha^{x i} \cdot(1-\mathrm{Pi} \alpha)^{1-x i}
$$

の式によるもので, $\mathrm{L} \alpha$ が最も大きかった病型が，もっ とも可能性のあるものとされる. 各症例においてこの計 算を行い，最大尤度が得られた病型が，央際の病型に一 致しているかどうかを調べた，単純失語では20症例が各 症型に最大尤度を示し，この症型が病変の部位との間 に, 特定の関係が存在しないことを示した。運動感覚障 害失語では32例のうち20例が計量診断で得られた病型と 一致し,この病型が脳の特定の部位との間に密接な関係 があることがわかった．浮動的感覚失語では10例中 6 例 が一致した。 また伝導失語は12例のうち11例が一致し， この方法でも病変部位と病型の間に密接な関係があるこ とがわかった.

考 察：失語全例の病変分布の状況からみると, 失語 症に特異的な分布というょり，脳血管障害を起こしやす い範囲を示しているように思われる。しかしこれを各病 型に分類すると, 病型と病変部位との間に密接な関係の ある場合が少なくない，それぞれの病型は失語症状の組 み合わせによって特徴づけられるものであるので，今後 は診断の基礎となった各症状と病変部位との関係につい て研究を進めたい.

質 問：金沢大・能登谷晶子 伝導失語の 責 任 病 巣 は, supramarginal gyrus〜angular giyrus といわれて いるが，今回の報告でも同じ結果となっているか.

応 答 : 虎の門病院・戸塚元吉 伝導失語でみられた 責任部位は小さく局限したものであったが，病例によっ てはこの部位を含む, さらに広い部分が侵されているも のもあった。 


\section{6. 受容型失語症における CT 所見の検討}

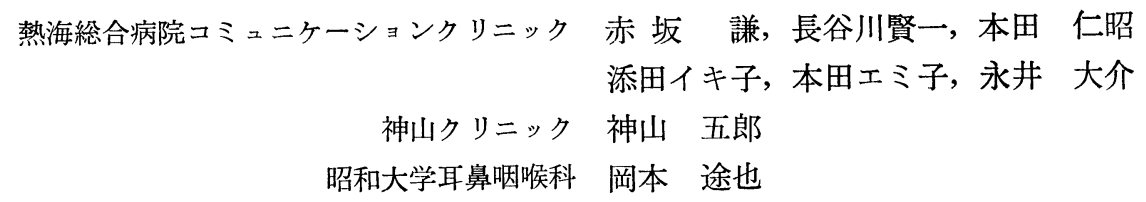

はじめに : 脳損傷の部位と範囲の推定には, 従来, 神 経学的諸検査, 脳血管撮影, 脳波, 脳シンチグラフィな どが用いられてきたが十分なるのとはいえなかった。し かし， CT scan の出現によりその欠点はかなり補われ た.したがって失語症の型, 重症度と, 経過, 予後との 関係の研究もさらに進歩寸るものと期待される. 今回 は，受容型失語症に和ける C T所見を，新しい観察装置 を用いて検討したので報告する.

対 象: 対象は熱海総合病院コミュニケーションクリ ニックで訓練し，CT scan を施行した失語症者のうち, 受容型失語症と分類された男 3 例, 女 1 例, 計 4 例であ る. 4 例とも利き手は右である.

症例 $1: \mathrm{YK}$, 男64歳, 脳硬塞 (右不全麻㽻). 経過 6 カ月, 重度失語症. 聴覚理解は注とんど不可, 音読はで きるが読んで理解することは不可, 自発語は流暢である が会話は不可, 書字はほとんど不可.

症例 $2: \mathrm{K} \mathrm{S}$, 男51歳, 脳硬塞 (右不全麻㽻), 経過 11力月, 中度失語症. 聴覚理解は不良, 読んで理解する ことは比較的よい. 自発語は発語失行を伴いやや不良, 書字はある程度よく会話時にしばしば用いる。

症例 $3: \mathrm{TM}$, 男46歳, 脳出血 (左片麻痺), 経過 7 カ月, 軽度失語症. 聴覚理解はやや不良, 読んで理解す ることは比較的よい, 自発語は比較的よいが会話中時々 場違いなことをいう．書字はややよい。

症例 $4: \mathrm{F} \mathrm{S}$, 女67歳, 脳出血 (左片麻痺), 経過 13 カ月, 中度失語症. 聴覚理解はやや不良, 読んで理解す ることはほぼよい，自発語会話とも jargon 様となる時 がありやや不良, 書字は不良.

方 法: CT scanner は, Siemens 社製 Delta scanner 50 を用いた. CT 像は cantho meatal line(CML) に平行な断層面で, $\mathrm{CML}$ より $8 \mathrm{~mm}$ 上方より, $8 \mathrm{~mm}$ ごとの12枚の断層像である。この CT 像を観察装置によ り検討した.

CT scan による12枚の断層像を overhead projector
を用いて実物大に拡大し，これを $22 \mathrm{~cm}$ 四方の透明なプラ スチック板に線画した上で損傷部を赤く染めた。このプ ラスチック板を $8 \mathrm{~mm}$ 間隔に重ねて観察装置とした。 こ れを上方よりみると脳が立体的に観察され，損傷部位を 理解することが容易となった．またこれを改良し，全反 射を応用することにより，側方拉よび前方よりみた脳の 損傷部位の推定が可能である.

結果および考察: 症例 1 は左上側頭回を中心に限局し て, また症例 2 は左上側頭回から下前頭回にかけて low density area を認めた. 症例 3 , 症例 4 は, 右上側頭回 および島に low density areaを認めた. 受容型失語症 を Weisenburg と McBride は「話しことば，書きこ とばの了解に和もな障害があり, 発語や書字にも障害が あるもの」といっている。これはほぼ Wernicke 失語に 相当する.「Wernicke 失語が出現するのは, Wernicke 領域, すなわち左上側頭回の後 $1 / 3$ のみならず, 上側頭 回, 中側頭回の後半分, さらに上縁回, 角回などの頭頂 領域にまで病巣が波及することが少なくない」,さらに, 「皮質領域のみならず，深部側頭葉䯣質の病巣からも Wernicke 失語は生じうる」と大橋は述べている. 症例 $1 ， 2$ は, これによく合致し, 症例 2 が発語失行を伴っ ているのは下前頭回まで損傷されているためと考えられ る.しかし, 症例 3,4 については, これだけでは説明 することができないすすなわち，受容型失語症は主とし て左上側頭回を中心とした損傷によって起きる，しかし 右上側頭回掞よび島の損傷によっても同様な症状があら われらる。

質 問：金沢大・鈴木重忠 右半球損傷の 2 例は, 言 浯の優位半球が元来右側にあったとするか，非交又性失 翡とするかのいずれかになるが，どちらと考兄るか．

芯 答: 熱海総合病院・赤坂 謙 言語の局在性およ び，失語症の定義などに問題があるのではないか，とい う疑問を持っている. 


\section{7. 急性期 CT 所見よりみた失語の有無および予後}

\section{清恵会病院言語科 熟野 公子, 石川 和代 清恵会病院䋞神経外科 谷掛 龍夫, 衣川一彦 大阪教育大学 竹田 契一}

はじめに：ここ数年来, 頭部 C Tスキャンの発達にお いて形態学的に脳の異常部位が比較的とらえやすくな り, 慢性期の病巣と機能の関連について多く述べられて きた。しかし急性期におけるそれは，あまり言及されて いない. そこで今回，われわれは救急病院の特質を生か し, 失語の早期診断の補助としての C T が有効である か, 若干の検討を加えた.

対象および方法 : 脳血管障害あるいは頭部外傷で清恵 会病院に入院し, 発症より 3 日以内に C Tスキャンを施 行した症例45例. 意識レベルが清明になった時点で, 言 語検査としてはS L T A および当院作成による日常生活 言語検査, その他を施行し, 以後, 言語検査, C T スキ ヤンを経時的に施行した. C Tは日立 $250 \mathrm{H}$ を使用し, それぞれの C Tスキャンで得た異常吸収值域を各水平断 面に投射した図を作成し，(1)障害部位別，(2)言語症状 別，(3)経時的に重ね書きを行った.

結 果: (1)Hayward らを参考に, 中心溝より前部拈 よび後部に障害部位をわけた急性期の部位別重ね書きの 結果, 中心溝より前部に障害の認められた症例は motor タイプの失語, 後部では sensory タイプの失語を呈し, 慢性期のそれとほぼ一致した。 また角回, 縁上回に障害 の認められた症例は, 復唱障害, 書字障害の強い傾向を 示した.

(2)言語症状別に重ね書きを行った結果, motor タイプ では中心溝より前部 (20例中 13 例), sensory タイプで は後部（11 例中 10 例）に重なり部分が多くみられた. total の場合, 中心溝より前部から後部にかけて広範な 障害部位が認められ，皮質下にも及んでいた（4 例中 4 例).また急性期に retrograde amnesia, mutism など ポツリポツリと話し, motor タイプの失語とよく似た症 状を呈したが，これらの精神症状がとれた時点で，失語 の認められなかった症例の障害部位は, 前頭葉前部に認 められた（ 5 例中 5 例).

(3) S L T A の II話す（呼称, 動作説明, まんが説明, 復唱) の改善度を比較すると, 意識レベルが清明になっ た時点から 3 力月までにほとんど改善された例は, 外傷 および限局性被款出血に多く，6 カ月経過した時点でも
ほとんど改善されなかった例は, 脳室穿破型出血, 硬塞 に多くみられた。また，意識障害が長く続いた例，およ び脳動脈硬化を伴う脳血管障害の例は, 失語の予後は不 良の傾向がみられた。

(4)同じ条件で C T スキャンを経時的に施行した症例 （45例中25例）を, 話しことばの改善度別にそれぞれ重 ね書きした結果, (1)改善度著明群（一過性失語あるいは 軽度失語を残す), 有群 (話しことばの改善はみられたが コミュニケーション上支障を残す）ともに, 経時的な $\mathrm{C}$ Tスキャンでは，異常吸収値域としてあらわれる深さ， 広さ, 高さに大きな変化はみられず慢性期 C Tスキャン に, 軽度の脳室拡大, 脳萎縮を認めた. (2)改善度不変群 （話しことばに拈いて，ほとんど改善がみられなかっ た）の経時的 C Tスキャンでは，異常吸収值域の深さ， 広さに大きな変化はみられないが，高さは広がる傾向が みられた（例，急性期では $2 \mathrm{~B} \sim 4 \mathrm{~B}$ に異常所見が認めら れたが，慢性期では $2 \mathrm{~A} 〜 5 \mathrm{~A}$ に広がっていた). また慢 性期 C Tスキャンでは, 著明な脳室拡大, 右半球におよ ぶ脳萎縮が認められた。

おわりに: 硬塞で発症より 7 カ月後の C Tスキャンで 異常所見の認められなかった症例が, 重度の motor 失 語を残すなど例外的な症例，また浮腫や手術による言語 症状への影響なども考えられるが，今回は症例数が少な いため, 言及されておらず, 今後, 研究の余地があると 思われる。

\section{本研究にご協力いただいた当院レントゲン科の皆様に深く 感謝する.}

質 問 : 虎の門病院・戸塚元吉 急性期 C T と慢性期 C Tとは, 重ね書きにおいてほぼ同一であったとのこと であるが, 個々の症例についても, 病変部位が変動した ものがなかっただろらか.

応 答: 清恵会病院・整野公子 異常吸収域のあらわ れ方に変化はある(例, 出血の場合 high density area $\rightarrow$ low density area). しかし, 障害部位の高さ, 広が り, 深さには, 大きな变化は涊められなかった. 
78. 長期に観察した発達性ジャーゴンの 1 例

\author{
長野赤十字病院 酒井 京子, 大塚 顕 \\ 埼玉医科大学神経精神科センター 佃一郎
}

幼児期より著明なジャーゴン症状を示した症例のこと ばが，どのように変化して行くのかについての検討は， 言語の発達を知る上で役立つと考兄る.われわれは先に 第19回本学会に执いて, 約 2 年間の観察・指導と集中的 な言語訓練を行った発達性ジャーゴンについて報告した が, 今回同一症例に関する 4 年後の状態について, 検討 する機会があったので報告する. 症例は, 現在 9 歳 11 カ 月の男児, 出産時異常なく, 身体的発達は良好, 医学的 既往歴にも特記すべきものはなかった. 家族歷として, 父親がアルコール中毒で加療中, 本児の生後 5 力月時に 入院，母親は本児を託児所にあずけて勤めに出た。 1 墄 2 カ月から父方の祖父母と同居, 招もに祖母によって育 てられていたが，2歳 9 カ月になってもことばがなく， 無意味な音をブッブッ言うのみであったので心配にな り，長野日赤脳外科へ精査のため入院した. 脳神経学的 には気脳写で透明中隔腔豊胞の所見以外医学的には異常 なく, 言語, 知能面の遅れを指摘され，同院言語課にて 約 2 年間観察指導などが行われた。この間，有意味語の 増加を認めたが，特有な抑揚を持った話し方をし，また ことばのェコーが多く，実用性に乏しいものであった。

5 歳 3 力月, 精神薄弱児通園施設飞入園. この時点で のことばの特徵は前回の発表にあるが，概略を述べる と, (1)有意味語と無意味語の羅列したジャーゴン様話し ことばが著明にある. (2)特有の抑揚を伴った echolalic speech がある. (3)“打いしいごはん食べたい”など長文 の模做が可能. (4)行動特徵として, 落ち着きがなく, 遊 びや一般行動上飞固執傾向が目立つ. (5)好き嫌い（食べ ものの)がはげしい，(6)不気嫌になりやすい，(7)集団行 動がとれない，など多様な問題をかか兄ていた。

6 歳 3 カ月になり併設の特殊学級に移ったが，集団行 動が少しとれるようになり，他児とのかかわりが可能と なり，興味のあるものに対しては15分ぐらい集中して椅 子に座っていられるなどの発達がみられた。ことばの面
では，大声でキャーキャー言らことと，ジャーゴン様の 話し方は変化なかったが, echolalic speech において本 児特有の抑揚から話し手の抑揚の模倣へと移った．音に 対する反応で特に花火音, ピストルの音, T V C Mのリ ンゴをかじる音などには，“もう打しまいるう拈しま い”と言いながら，耳をふさぐ行動が見られた。

7 歳になり仮名文字を教えると， 3 カ月目に自分の各 前の 1 文字「上」が自発的に書け，その後文字に興味を 示し， 3 年生の始め頃にはほ涪全音書けるよらになっ た. 9 歳 5 カ月頃には日記が書けたが，文章化はなかな かできず，“ごぜんちゅらはべんきょらをしましたおや すみはなしごしきらどんらりさぎようなつみかんぜんこ うじしろえんぴつけしごむ……”とその日にあったこと がらを，単語を羅列するように書くようになった。

現在の行動上の特徵としては, 特定の興味あるものへ の繰り返しを行ら。たとえばブラインドを上げ下げする などが目立っている。ことばの面では呼称が 100 語中73 語可能で, 少し了解しにくい絵でも, ヒントを与えれば 90〜95\%可能であった. 䛊りの傾向としては，「洗濯機」 を「洗䍜物」などがある。

以上, 2 歳 9 カ月から 9 歳11カ月までの発達の概略を 追ってきたが，頭初の著明なジャーゴン様話しことば が, echolalic speech を経過し, ほ涪単語レベルか短文 でのコミュニケーションがつくようになった症例につい て報告した.

な怙，C Tスキャンの結果では，障害を予測するよう な所見は得られなかった。

質 問：浜松医療センター・河原めぐみ 症例に I T P A, 視知覚発達検査を実施したか否か, 実施した場合 結果を教えていただきたい。

态答: 埼玉医大・佃一郎 I T P A 扰よび視知覚 発達検査（フロスティッグ）は行っていない。 
79. 小巟失語症の改善経過

\section{竹田綜合病院言語科 古川 博子}

目 的：小児失語症に括いて子両側性損傷の場合，回 復は不良といわれている. われわれは両側性Moya Moya 病の症例に対し 6 力月間の訓練を施行し, 著明な改 善をみたのでその経過について報告する.

症 例：6 歳 9 力月女览. 右利き. 昭和 52 年12月 29 日 ふつうに遊んでいて突然嘔吐．意識障害はなかったが発 語は全くなく，家族が何を聞いても泣くばかりであっ た. 翌朝右片麻痺が出現し某病院受診. 左右の頸動脈写 で両側の内頸動脈の閉塞および異常血管網が認められ Moya Moya 病と診断された. 昭和 53 年 1 月 20 日 CT scan で広範囲な脳皮質の萎縮ならびに右前頭葉正中奇 り，および左視床後部に低吸収域が認められた。発症後 77日言語治療を目的として当院に転院. 当院での初診時 所見では神経症状として右片麻痺, 言語症状として表出 面の障害を主体とする重度失語症が認められた，初回 $\mathrm{S}$ L T A 検査, 話す能力ではわずかな単語のみで，それも 語頭音を与えなければいえない状態であった．聴いて理 解する能力では，単一な課題に対する反応は良好であっ たが，課題が複雑になると困難であった，読んで理解す る能力, 書く能力は仮名文字の想起が困難なため反応困 難. 計算能力は基本的な数概念の障害が著明で不可能で あった．訓練は当初日常会話の対応がとれるようになる ことを目ざして，患者が一番興味を持っていた仮名文字 を手がかりに進めていった。

訓練経過：訓練開始 3 力月後，話す能力は呼称で $65 \%$ まで可能となり，日常会話においても片言ながら自己の 思考表現ができるようになってきた，さらに訓練目標を 復学にまで進めて課題を強化した. 6 力月後呼称は $85 \%$ と増加し，逐語的な話し方ながら日常生活におけるコミ ュニケーションは, ほとんど問題なく行われるまでに 改善した，聴いて理解する能力では 3 カ月後, 複雑な課 題にも反応できるようになった．読んで理解する能力, 書く能力に打いては著明な伸びがみられ, 読みでは 6 力 月後, 仮名単語は $100 \%$, 短文でも $40 \%$ まで可能となっ た. 書く能力では, な行, ま行の文字に遅延反応がみら れ, 文字を単語の語頭音と結びつけて想起して書く状態 であった. 6 力月後, 拗音, 捉音を書くことに困難がみ られる程度で50音は容易に書けるようになった。計算力 は 1〜10までの数概念を習得し，現在では繰り上がりの ある 1 桁加算が可能，減算は困難である．これを同年踚
正常児 8 名の平均値と比較してみると, 聴く, 話す項目 の複雑な課題においては, まだかなりの低下がみられる が，仮名文字の読み書きはほぼ闹レベルまでの改善が認 められた。

W I S C 検査は初診時反応不可であった言語性が，訓 練 6 カ月後ではI Q80までに上年し，動作性においても 初診時 I Q69 であったのが I Q80 と 25 の上昇がみられ た.この時期の CT scan では広沉な両側脳皮質の萎縮 と, 三角部执よび後角に最も著しい雨側脳室拡大が認め られた。

まとめ：小児失語症でも两側性損傷は回復不良といわ れている. 本例に拈ける初診時所見では, 話しことばは 語頭音を与えないと単語もほとんど言えない状態であ りまた理解力においても複雑な課題には反応困難で表 出面の障害を主症状とする重度失語症であった。病巣の 検索は CT scan によって行われたが発症時両側脳空の 拡大と広沉な大脳皮質の萎縮を認め, 6 力月後の C T 所 見でも著変はなかったにもかかわらず，言語面では日常 会話におけるコミュニケーションはほとんど問題なく行 われるまでになった. Byers らは小児の大脳半球の機構 は, 障害された半球の機能が健側半球に移行し得るだけ でなく，おのおのの半球内においても，部分的な損傷に より損われた機能に対し，非損傷部位に㧊いて代償し得 る可塑性を有すると述べている. 本例の場合は，小児大 脳半球の可塑性に富んでいることを示唆し，言語訓練の 必要性を強調するものである。

質 問: 奈良医大・飯田良樹 Moya Moya 病患者の 失語症を生じた原因は何か（出血か硬塞か steel syndrom か).

C T上脳萎縮がみられたが，これは失語症発症前から あったものではないか.

応 答：竹田綜合病院・古川博子 脳硬塞である.

発作までは全く異常がなかった. 初診は発作の翌日だ ったので，発作前から萎縮があったかどらかは不明であ る.

な打発症から CT scan 施行までは，23日であった。

質 問 : 虎の門病院・戸塚元吉 発病後24日目のC T 像で，広汎な脳萎縮があったといらことであるが，この 萎縮は発作前からあったものではないか.

応 答：竹田綜合病院・古川博子 飯田氏への応答を 
参照されたい.

質 問 : 金沢医大・相野田紀子 話想起以外のスピーチの特徵, たとえば構音, prosody の面ではどのような
問題があったのか，もしあれば，その改善過程はどらか。 応 答：竹田綜合病院・古川博子 prosody の障害は なからた。

\title{
80. 脳硬塞による小览失語の回復経過
}

\author{
新潟労災病院言語科 大山 英雄 \\ 竹田綜合病院言語科 鶴岡 はつ
}

はじめに：成人の失語症に比べると，小児失語症はま れであるといわれている.今回われわれは脳硬塞による 小児失語症を経験したので，神経学的所見および言語の 回復経過について報告する.

症例： 5 歳 6 力月男児. 右利き. 意識障害. 右片マヒ. 失語症で突然発症し，脳神経外科へ入院した。全身状態 には軽度の発熱と脱水がみられた．神経学的所見では右 顔面神経マヒ (中权性), 右上下肢の運動マヒを認めた。 血液，䯣液所見には異常を認めなかった．脳波では左半 球全汎に徐波が夕られた。左頸動脈写では左中大脳動脈 の皮質枝に数個所で閉塞がみられた. さらに CT scan では，閉塞血管の支配領域に一致して左前頭葉外側部か ら内包，基底核におよぶ広汎な低吸収值域がみられた。 言語症状とその回復過程；初診時（発症より 8 日）自発 言語はなく指示に従った動作の模倣が，わずかに可能で あった．言浯症状の安定した発症 2 月後の S L T A で は, 聴く能力; 単語の理解は60\%正答, 短文の理解は50 \%の正答であった．話す能力；自発言語はみられず，問 いかけに対してはわずかに「うん」「ららん」，をもって 思考表現を変えるのみであった。

以上のことから表出面の障㕩を主体とする重篤な失語 症として，病前の話しことばの再習得を目標とした言語 訓練を開始した。訓練は単語の模倣・絵カード（高頻度 語）による呼称を中心に，1回45分で週 6 回行った. 訓 練開始後 1 力月(発症より 3 力月)の S L T A では, 聴く 能力; 単語の理解は $100 \%$ の正答, 短文の理解でも $60 \%$ の正答を示した. 話す能力; 単語の模倣および自発言語 がわずかにみられるようになった．この時点での wppsi では, 菩語性, 反応不可, 動作性 I Q57であった.

訓練開始後 3 力月(発症より 6 力月)のS L T A では, 聴く能力; 口頭命令に従うなどの複雑な指示に対して50 \%の正答を示した. 話す能力; 単語の呼称では70\%の正 答を示し, 語頭音を与えるとほぼ $100 \%$ になった. 動作 絵の説明では, 動詞の想起が困難なため50\%の正答であ
った. まんがの説明では段階 4 を示した。自発言語に抒 いては，問いかけに対する反応は不十分であったが，思 考表現は電文体で適切に行えた. この時期の wppsi で は, 言語性 I Q73, 動作性 I Q81を示した.

発症後10力月のS L T A では, 複雑な口頭命令で $80 \%$ の正答を示した．話す能力；動作絵の説明で70\%の正答 を示し，まんがの説明で段階 5 となった。自発言語では 電文体の残存を認めたが日常会話に十分追従可能であっ た. 読さ能力では, 仮名 1 文字がわずかに可能となっ た. 書く能力では; 病前には書けなかった自分の名前が 書けるようになった。

まとめ: 小児に扔いては大脳機能の局在が完成されて いないため, 失語症の予後は比較的良いといわれてい る. 本症例の失語症をきたした病巣は，CT scanなどで 左大脳半球の広汎な損傷にあることが確認されて抢り, 失語症状の良好な改善がみられた発症 5 力月後の, CT scan では左半球にみられた広沉な低吸収值域の，わず かな縮小が認められたにすぎず，同時期の amytal sodium test では, 左頸動脈に合計 50〜 70mg の注入を試 み，模倣言語抢よび数の順唱が可能であることを確認し た.さらに右頸動脈に同一方法で施行した。この時は自 発苦語がみられず，泣き声を聞くのみであった。

以上のことから言語の表出に右大脳半球が関与してい るものと推定した.このことは，小児の大脳半球の機構 は障害された半球の機構が健側半球に移行して, 代償し 得る可塑性を有していることを示唆するものであり，発 症後約 1 年の現在病前にはみられなかった「読み」,「書 き」も新しく修得されている，したがっていかなる重篤 例に対しても，機能回復訓練は十分実施されなければな らないとの印象を強くした.

質 問 : 金沢大・能登谷晶子 小胃失語症の自然治療 期間についての考えを教えてほしい.

応 答 : 新潟労災病院・大山英雄 小児の場合では, 言語が発達途上にあるために，との回復を自然治療とい 
うべきか，言語発達というべきかはわからないが，本症 例は 2 力月位で一応固定した症状を示し，その後発達 （回復）過程をたどった.

質 問: 都養育院病院・福迫陽子 amytal test の結 果から，言語中枢は右へ移行したと思われるのか。それ とも発作前から右にもあったと解釈していられるのか. 提示された症例は，な扮言語発達過程にあるが，発達 に関する検査においてどのような特徴が認められたか.

応 答: 新渴労災病院・大山英雄 本症例の場合, 発 症後に右大脳半球に言語中枢が移行したと考兄られる.

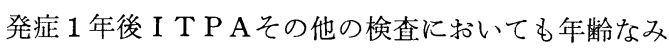
の言語発達を示し，病前にみられなかった読み書きがみ
られるよらになった。

質 問 : 金沢大・鈴木重忠 劣位半球による再学習だ とすると，歌やイントネーションが先に回復することが 考光られるが，本例では言語が歌より晕れて，再学習さ れることはなかったか.

芯 答 : 新潟労災病院・大山英雄 本症例ではことば の回復が早くみられた.

小児の場合, 左右の大脳半球の機構が確立されていな いため，成人で右大脳半球の機能といわれている歌，イ ントネーションなどが小児の場合, ことばよりも遅れて も良いのではないかと思われる。 


\section{1. 視覚言語について（その 1)}

\section{伊豆聥信病院第 1 理学診療科 勝山 和長, 小野 順一}

言語は知覚あるいは表象の時空的埸において個別化さ れ，限定された有機的統一としての心理的諸事象の表現 手段として捕えられる. この時「文章」は心理的事象の 内部的分節の様子, すなわち単一種類の力の存在に関連 しているとみられる各部分，およびそれらの関係の知覚 の様子の，また「文」は特に単一種類の力の存在に関連 しているとみなされる部分の様子の「言語表現」を指す ものとして考えられる. 今回は言語記号の素材に平面図 形を用いた時，このような「文」の表現形態に関する考 察拉よび簡単な実験結果を報告する.

単一種類の力の存在に関連しているとみなされる心理 的事象部分は, ほぼ無限の種類の状態をとると考学ら れ，言語はこれを記号を用いて表現するものであるが， 人間の記憶能力を考える時, 当然これを補ら工夫が必要 となり,この種の工夫の要点は次のようになる.すなわ ち，心理的事象部分はさらに内部的分節を示し，さまざ まな要素およびそれらの関係の知覚が得られるが，この 段階でこれらに基づく各種のパタンを任意にいくつか設 定してしまい，この各パタンに対して特定の記号素を対 応させて，表現すべき事象をこれらの記号素の構成とし て示すことや，さらに記号素をいくつかの要素の構成体 とすることである：また，実際の言語使用を考える時， 以上のような記号の性格に基ついて，記号と実際の心理 的事象の間で相互変換が容易に行われるためには，各記 号は速やかに弁別されねばならず，したがって記号の形 態は用いる素材により，定まる情報処理系の低次のレべ ルでパタン処理されるようなものであることが，条件に なると考兄るよって言語記号の素材に音声を用いた場 合に相当する音声言語は，以上のようなことが表出系や 情報処理系の制約や特性の中で満たされた時の言語の姿 として, 記号素やその構成要素 (音素) が線状に並ぶこ とや，記号素が結びつくパタン設定の仕方や，それによ り各パタンが実際の心理的事象の中で示す関係を表現す るさまざまな方法の特徴を㲾すものである. そして記号
の素材として平面図形を用いることを考える時, 図形の 表出系执よび情報処理系の制約や特性を考慮すること で，その特徴などに関して次のような結諭を得た. (1)さ まざまな傾きの直線が機能的に弁別素性に対応するこ と. (2)記号素やその要素さらには弁別素性的直線の配置 は線状ではなく，各位置関係が角度の認知から捕えられ るようにすること. (3)特に「動詞」の機能に類似するこ とになる記号素が結びつく対象を相互作用パタンに限定 すること. (4)「格助詞」の機能に対応する「各パタンが 実際の心理的事象の中で示す関係を表現する方法」は記 号素の位置を指定するワクを用いて，その位置関係によ り表現すること. (5)「漢字」や朝鮮の「ハングル文字」は 記号素として望ましい図形であること. (6)用いられる記 号素や記号素の要素図形をあらかじめ示しておき，必要 な部分を選択的に示す方法で言語を運用することが望ま しいこと. (7)仮名は要素が線状に並ぶため, 記号素の単 位では視覚系低次レベルでのパタン処理が困難となり， 意味に結びつき難いものであるが，各要素を次々と音に 直すことで線状構成を生かし，その結果「音声言語の記 号素」として対応すべき心理的事象に基づいて, 設定さ れたパタンとの結合が可能となるものであると考えられ ること.

以上を考慮して得られた「平面図形による文」を用い て次のよらな箺験を行った。

実 験 : 10種類の「文」を平面図形, 文字, 音声にて 示してこれに対する行為を教示し，その後「文」の提示 順を変えて各「文」の表示に対する行為の評価を，各表 示法につき 4 回繰り返し成績を調べた。被験者は非失語 症者, 失語症者各 1 名で, 失語症者は典型的な重度 motor-type であり視覚系の障害は特にないと思われた.

結 果: 今回作成した「文」の平面図形記号による表 示法は, 少なくともこの種の type の失語症者に対する 情報 input 手段として有効であると思われた。この表 示法の評価はさらに検討が必要と考光る. 


\title{
82. 失語症検查について（その 1)
}

\section{伊豆莪信病院第 1 理学診療科 勝山 和長}

言語音刺激が聴覚器官に加えられた時，㝋の（時間的 に変化する) エネルギーは，独特の構造を持つ神経系を 伝播し，意味の実体としてのレベル，すなわちさまざま な心理的事象を形成するレベルでの神経系の活動をも， もたらすと考えられる。

この時, 神経系の各レベルでは, 音声入力に対し，そ のレベル以下の神経系の構造を反映した多次元のパタン が生じていると思われる。こう考える時, 音声言語によ る意味理解とは, 音声言語刺激により, 意味実体として の神経系の活動が生じるレベルで, あらかじめ, その与 えられた言語刺激に対応するものとして任意信定され た「心理的事象としての特定のバタン」を生じることで あるとい光，さらにこの意味レベル以下の，聴覚系での さまざまなレベルに抢ける音の特徴栓出結果バタンをも 考虑することで, 弁別素性, 音素, 音節, 形態素, 語, 文などの音形の特徵を捕えることができると思われ る.

ところで、失語旗者の（音; 卓) 語理解の障害は, 神 経系の器質的障害により, 先に述べたようなレベルのぞ こかで, ハタン特徵検出の障害や，その結果としてパタ ン形式の変谽が生じ, その結果, 意味レベルに打けるバ タンの変化, 寸なわち, 心理的事象としてのさまざまな バタンを持つ諸活動のらち, 特に inputさ机た音声言語 刺激に対応すべきものとして，任意に定められたバタン をとる活動の選択や，それらの構成が正しくなされなく なった状態として捕えることができる.

したがって, 失語症者の音声言語理解能力の評価は, 単に音声刺激を与えた結果, それが意味レベルにどう反
映しているかを，その結果形成された運動プログラムに 基づく行為からの評価や, 他知覚経路よりもたらされた 意味とのマッチング成績を調べるだけでは全く不十分で あり, 音卢言語 input 時の聴賞系の途中の各レベルでの パタン形式や，特徵娭出機能の状態を調べることが必要 であると思われる。このようなことを調べる手段とし て, 聴覚系各レベルでのパタン特徵検出の結果として得 られる情報が，解決に特に必要となるような課題を用い れば良いと考えられる。

一方, 意味の音声言語による表出を, 特定の意味パタ ンに対し，それと同じものをもたらす音声言語刺激が， 聴覚系の各レベルで形成するよらなパタン特徵を捕光, それを発声により奏現することであると考えた時, 言語 表出能力の評価は, 単に聴覚系路以外の知覚系を用いて 形成された特定のパタンを持つ意味に対して，表出され た言語の様子を調べるだけでなく, 聴覚系の各レベルに 生ずるパタンの特徽が，どのように構成され得るかを捕 える能力を調べる必要があると思われる.

以上のようなことより，失語症検查としては語音の抽 出や構成を調べることが, 音声言語の理解や表出能力の 評価として重要となるわけだが，今のところ，語音の抽 出の一部である「音節抽出恰査」しかみあたらない。

そこで，さまざまな，语音の抽出や構成の検査を行う 手段として，配列された 6 個の「スイッチ」のどれかを 押すことにより，それに接続された「エンドレステープ コーダ」からの音声が，いつでも聞かれるような装置を 試作した。これを用いての言語検査を現在検討中であ る.

\section{3. 失語症患者における視・聴覚入力の競合性に関する検討}

\author{
熱海総合病院コミュニケーションクリニック 長谷川賢一, 赤坂 謙, 本田 仁昭 \\ 添田イキ子, 本田エミ子, 永井 大介 \\ 神山クリニック 神山 五郎 \\ 昭和大学耳鼻咽喉科 岡本 途也
}

はじめに: 失部症者の浯語訓練に抢ける原則は，まず 適切な刺激を与えることである、言語に関連する感覚刺
激しとては，聴觉刺激と視覚刺激の 2 つが考光られる. 臨床の場面においては，患者にとってどちらの刺激がコ 
ミュニケーション機能の効率に影響を与えるかが問題に なる、そこでわれわれは, 聴覚刺激と視覚刺激を同時に 与え，両刺激の競合性について検討したので報告する。

対 象: 当院に入院中の失語症者で現在当クリニック において処遇している者28名である。

研究方法 : 研究は, 視・聴覚同時刺激 4 , 単刺激 4 の 合計 8 つのストから構成されて抢り, その内容は, 次 の通りである.

テスト 1 ；音と絵刺激を与え絵を指す.

テスト 2 ; 音と文字刺激を与え文字を指す.

テスト 3 ; 音と文字刺激を与え絵を指す.

テスト 4 ；音と絵刺激を与え文字を指寸。

テスト 5 ; 文字刺激を与え絵を指す.

テスト 6 ; 音刺激を与え文字を指す.

テスト 7 ; 音刺激を与え絵を指す.

テスト 8 ; 絵刺激を与文字を指す.

テストは，6個の絵または文字の中から与えられた刺 激に対応するものを指すといら反応形式によって行っ た。

刺激は，VTRにより異なった視・聴覚刺激を闰時に 1 秒間与えた（例：視覚刺激には猫，聴覚刺激にはゴハ ン.これを同時に与える). 文字刺激には，漢字を使用 した．テスト方法が一般的でないため，テストに入る前 に例題を繰り返し実施し方法を十分理解させるよら配虑 した.

結果および考察 : 単刺激時の各テスト (10点満点) に おける平均得点は, テスト $5 ; 8.2$ 点, テスト $6 ; 8.3$ 点, テスト $7 ; 8.5$ 点, テスト $8 ; 8.7$ 点であった. 各テスト 間の平均得点, 得点の分布にほとんど差は認められず単 刺激時のテストの性質, 難易度に差はないものと考えら
れる。

同時刺激時の結果は, テスト 1 では, 絵刺激>音刺激 の者18名, 音刺激 $>$ 絵刺激の者 5 名, 絵刺激=音刺激の 者 5 名, テスト 2 では, 文字刺激>音刺激の者 17 名, 音 刺激 $>$ 文字刺激の者 5 名, 文字刺激=音刺激の者 6 名, テスト 3 では, 音刺激〉文字刺激の者20名, 文字刺激> 音刺激の者 5 名, 文字刺激 =音刺激の者 3 名, テスト 4 では, 絵刺激>音刺激の者 15 名, 音刺激>絵刺激の者 10 名, 絵刺激=音刺激の者 3 名であった．刺激別の平均得 点は, 数例をのぞいて単刺激時の平均得点よりいずれも 低下して扣り，競合刺激による影響が認められる.

単刺激と同時刺激テストの結果より音, 絵, 文字の三 者の刺激性の強さを推定した. 音刺激時は, 競合刺激が 文字より絵の場合に音刺激の得点が多く, 絵, 文字刺激 時は, 競合刺激が音で絵刺激時より文字刺激時に得点の 低下が多い。すなわら，いずれの条件においても競合刺 激・文字が他に与古る影響は少なく, 迎に他の刺激の影 響を受けやすい，音と絵については，競合刺激が音より 絵の場合に得点の低下が多く認められる. 以上から，三 者の刺激性の強さは, 絵>音 >文字であると考えられ る.

$\mathrm{S}$ Tによる患者のタイプ分類（視覚型か聴覚型かの分 類）上，本テストによるタイプ分類との一致率は，テス ト $1 ; 43 \%$ ，テスト $2 ； 46 \%$ ，テスト $3 ; 46 \%$, テスト $4 ; 54 \%$ であった。一致率の低い要因としては, 競合刺 激があるなどテスト方法が一般的でないこと, 単語レべ ルでの判定であることなどが考えられる。

以上, 本研究から患者のタイプ分類にはさらに検討の 必要があること, 音, 絵, 文字の三者の刺激 性の強さ は，絵＞音＞文字であることがわかった.

\section{4. 失語症患者の Non-verbal Communication について（その 2）}

\section{有馬温泉病院言語科 熊倉 勇美，田中 春美}

前回われわれは，失語症が重度になればなるほど，そ の必要性とは逆に，ジェスチャ一能力は低くなる傾向の あることを明らかにした，今回は「ジェスチャー能力を 訓練によって変えることはできないか?」と考光以下の ような実験を行った。

重度失語症患者の多くは, ジェスチャーを自発的に用 いることができず，模做することも難しかったが，比較 的ジェスチャ一能力が高い 2 名 ( $\mathrm{K} ・ \mathrm{O}$ 一男性, 47歳, 外傷性脳内血腫術後, $\mathrm{M} \cdot \mathrm{T}$ 一女性, 56 歳, 脳出血）を
対象として選んだ.ジェスチャー訓練は名詞単語を 30 語 選び，第 1 期・第 2 期とに分け 1 回約 30 分, 全部で 23 回 行った.

訓練開始前・中・後に訓練には用いない20枚の名詞絵 カードでジェスチャーをさせ，VTRに収録し変化の有 無を検討する資料とした。招の扮のの患者の訓練目標は 以下の通りである。

$\mathrm{K}$ ・ $\mathrm{O}$ : 第 1 期…手がかりを誘導によって引き出す. 第 2 期…同じ. 


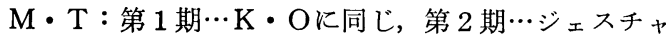
一を覚えさせる。

具体的な訓練方法は以下の通りである. 名詞絵カード をセラピストが患者に提示し，それを知らない相手役 （付き添い）にジェスチャーで伝光させた．患者が呼称 することは禁じたが，他の口答表現は特に禁じることは せず「ジェスチャーでやって下さい」と促した。なおそ の過程で以下のことを行った. (1)形が曖昧な時にはセラ ピストの模做をさせて修正させる．(2)余分な動作をした 時には，それが余分であることを知らせる. (3)手がかり が出ない時には，「どうやって使いますか?」「どらや って使いますか？」「どうやって飲みますか?」などと ヒントを与える. (4)手がかりがどうしても出ない時はセ ラピストが教える.

以上の結果, ジェスチャー訓練の開始前・中・後の 20 枚の名詞絵カードでみたジェスチャーの変化は以下の通 りである.

$\mathrm{K} ・ \mathrm{O}:$ (1)訓練開始前に比べ，第 1 期終了後は jargon speech が減少し, やや適切な擬音語, 擬態語がみられ るようになった. (2)第 2 期終了後は jargon speech が再 び多くなったがその中に有意味な「もしもし」「えーと」 などバラェティーに富んだロ頭表現がみられるようにな った. (3)ジェスチャーそのもの，つまり線の描き方，大 きさ，手がかりに関しては変化がなかった.

$\mathrm{M} ・ \mathrm{~T}$ ：訓練の開始前は手のひら全体を使って線を描 いていたが，第 1 期終了後，打拉まかな線は手のひら で，細かい部分は指で描くようになった．他には特に変 化はみられなかった．訓練中に観察された変化は以下の 通りである。

$\mathrm{K} ・ \mathrm{O}$ : (1)自発的に行った手がかりや，教えた手がか りが若干定着した. (2)絵カードを見てからジェスチャー を開始するまでの時間がやや速くなり，手がかり同士の つながりがスムーズになった. (3)擬音語・擬態語がやや 増えた。

$\mathrm{M} ・ \mathrm{~T}$ ：特に変化は認められず，訓練への意欲が徐々 に減少した.

さて, われわれは発語面の障害が強く，一定期間の訓 練の後に変化がみられなくなった場合, 他のコミュニケ ーションチャンネルの中から有効なコミュニケーション
方法を捜すことができないかと考光，実際にもいろいろ な訓練を試みてきている。

今回はその中で非言語的コミュニケーション，特にジ ェスチャーが果たして訓練によって変わるかどらか, 実 用的な意志伝達の方法になるか否かを 2 例についてのみ ではあるが陚みた。その結果 $(\mathrm{K} ・ \mathrm{O})$ に沶いては，病 院内の日常生活でジェスチャ一, さらに有意味な発語の 使用が增えたが，婜用的なコミュニケーション方法とは ならなかった。

今後の課題としては，以下のようなことが残されてい る. (1)引き続き症例を集めること. (2)なぜジェスチャー が実用性を持ち難いのか, 患者自身の興味・意欲・必要 性などから考える。(3なぜジェスチャーが難しいのか, 失行との関連から検討する。

質 問：金沢医大・相野田紀子 (1)第 1 例でジェスチ ヤーの訓練の効果がみられなかった理由は. (2)ジェスチ ャ一訓練の位置づけは, 将来, どのようなタイプの, ど のような程度の失語患者にジェスチャ一訓練を実施する 予定か.

応 答 : 有馬温泉病院・熊倉勇美 (1)病前からの患者

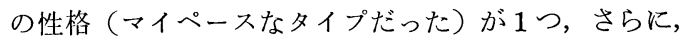
ダメージの大きさからくる全般的知的低下が考学られ た. (2)重度失語の場合には, ジェスチャーなど非言語的 コミュニケーションで補うということは, 結局難しいよ うだ。悲観的な意見を現在は持たざるを得ない。

質 問：七沢病院・竹内愛子 失語症者のパントマイ ムやジェスチャーの障害に関しては, simbolization の 障害によるとする説と，合併障害としての apraxia によ るとする説があるが, 後者の立場をとるとすれば, 失語 症の重症度とパントマイム・ジェスチャ一の能力が顕著 に分離した症例が出てくることも可能だと考えられる が，そのような症例は経験されていないか.

応答: 有馬温泉病院・熊倉勇美 重度の場合, ジェ スチャー（非常に simple なもの, 食べる, 持つ etc) をさせても, 難しいわけだが，指示が入らない，指示は 入ったようだがどうして良いかわからない, etc, できな い因子が多すぎて apraxia などの問題を考えるには不 適当のように思う，中度，軽度で検討していくと良いよ らに考える。 


\section{5. 電話利用による言語訓練（第 2 報）}

関東违信病院 大坂みどり, 冷牟田英三, 松本 和子, 上野 憲子, 渡辺薰 大阪教育大学 竹田 契一

目 的：マンツーマン訓練を経験せずに，リハビリテ ーションでんわ（以下略してリハでんわとする）のみを 行ったケースについての言語機能の変化を検討する．参 考として心理的変化について, 発症後長期間言語訓練を 受けられなかったケースについての㖜練前後の結果につ いて考察する.

方 法: 言語機能の評価は S L T A, 心理的変化はY G 性格検査を用いた.

対象結果：リハでんわのみを施行したケース 9 名中， 発症から訓練開始までの期間の短いもの，および本人に 積極的訓練意欲がなく中止したもの計 5 名を除き，4名 そついて検討した.

症例 1 : 50歳, 男子, 原疾患は脳血栓, 失語症タイプお よび重症度は運動性失語症の中度, 発症から訓練開始ま での期間は 4 年10力月, 職業は電力会社で閑職. S L T $\mathrm{A}$ の結果は初回時と10カ月後の再評価のプロフィールに 顕著な改善がみられた．特に口頭命令に従う，呼称，話 しことばによる動作説明およびまんが説明，書字命令に 従う。仮名単語の書字，短文の書き取りである，用いた 教材および訓練内容のおもなものは, 文の復唱, 状況画 による呼称，文章音読，文末完成，短文扣よび長文(300 字程度）の助詞挿入，誤文訂正，まんが説明などであ り, 状況画や音読教材は前もって渡しておいた，Y G 性 格検査の結果はタイプ判定は C 型で変化はないが項目別 では，情緒的には神経質でないに移行，社会的には協調 的に移行, 主導的には社会的外向に移行が顕著な変化で ある.これは心理判定員によると, 一般的行動力の変化 がおもなもので，気軽に行動できるようになったと評価 してよいとのことである.
症例 $2: 43$ 歳, 男子, 原疾患は脳血栓, 失語症タイプ および重症度は運動性失語症の中度と判断され, 発症か ら訓練開始までの期間は 2 年 6 力月, 職業は酒屋自営業 である. S L T A の結果は初回時評価と 4 力月後の再評 価の結果では下記の点に改善が著しい. 話しことばによ る動作説明执よびまんが説明, 漢字単語の書字, 畫字に よるまんが説明である. 用いた教材扎よび方法は, 短文 の音読，文末完成，短文による助詞挿入などがおもなも のである.

他 2 症例については簡単に述べるが，発症から訓練開 始までの期間は 8 カ月拈よび 2 年 3 カ月である. 失語症 タイプおよび重症度は両者共運動性失語症の中度と判断 される.これらのケースにおいても，下記のよらな言語 機能の改善がみられた. 話しことば全般, 音読が著明で ある。

まとめ : (1)症例はすべて発症から訓練開始までの期間 が長期であるにもかかわらず，言語機能の改善がみられ た。またこれらのケースはリハでんわ以外の訓練を受け ていないのでこの改善は, リハでんわによる訓練効果と いってよいのではないかと思われる.

(2)症例 1 の Y の結果からみられる心理的变化も，リ 八でんわによる訓練効果の 1 つと考兄られ，これは第 1 報で述べたアンケートによる心理的変化の結果を裏つけ たものと考えられる.

おわりに : 第 1 報で述べたリ八でんわの利点を生かし 地理的・身体的・時間的制約で入院, 通院ができない患 者への訓練方法として，非常に有効であると判断され る. 今後さらに多くの症例検討を重ねて細部の検討を加 壳たい

\section{6. 失語症と Delayed Auditory Feedback (DAF)}

\section{東北大学教育学部 永淵 正昭, 伊藤 友彦}

delayed auditory feedback(DAF) が発声発語に変化 をもたらすことはすでに知られた事丰であるが，今回は 失語症患者について検討したので報告する.
被検者 : 失語症患者は健忘失語, 伝導失語, 感覚失語 運動失語の 4 つのタイプに分けて, それぞれ数名（年龃 ；24～69歳）を被検者とし，対照群としては正常者（50 
代，男）を20名選んだ.

実験方法：DAF-34（トリオ）を用いて delay time $200 \mathrm{msec}$, 音圧約 $80 \mathrm{~dB}$ (オージオメー夕目盛) で両耳 にフィードバックした.

実験は 50 音表の朗読(各行を約 1 秒で読むように指示) と, 12 語の単語（ 4 音節以上）の復唱を NAF（normal auditory feedback, 普通の状態) と DAF のもとで行 い，その時の発語を録音し high speed level recorder （リオン）で分析して，正常者と失語症患者を比較し た.

試行時間は 1 名につき 5 10分程度であった.

\section{結 果 :}

(1) 50音の発音

(1) 正常者: NAFでの発声時間は各行とも約 1 秒で あり, D A Fでのそれは 1 秒から 2 秒の間に分布してい た.

次にD A F による発音の変化では構音の誤りはなく， ウ列，エ列を主とした語の反復（例：カキククケ卡コ， ラリルレルレロ）がよくあらわれた。この反復はア行で 少なく，サ行やマ行で多い傾向がみられた。

(2) 失語症患者: 失語症のタイプによって多少異な る. i ) 健忘失語 (7 名)；NAFでの発音は正常者と 同じであるが，D A Fでは発声時間が大きく延長してい る. 発音の変化は正常者と同じく語の反復で, ウ列が最 迤多かった。 ii) 伝導失語（6名）; 発声時間をN A F とDA Fで比較すると, 後者で多少延長するだけで, 健 忘失語群と対照的であった，発音の変化は軽症例ではD A F で語の反復がみられるが，重症になるほど子音の置

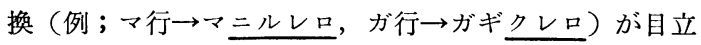
つようになった。 iii) 感覚失語（5名）と運動失語（7 名）は重症例を除いたが，NAF効果はいずれも類似し た傾向を示した．まず発声時間であるが，NAFで2〜 3 秒を要し，D A Fで若干延長している程度であった。 次に発音の変化であるが, 軽症例の 3 名は語の反復で, 残る中等度 9 名は子音の置換であり, それも不完全なも のが多かった（例；ザ行 ーサシス，各行すべてーアキッ テト).
(2) 単語の復唱

(1) 正常者：NAFでは鿁る者はなく, DAFでは各 単語とも 3 音節までは正しく構音するが，4 音節以後で 反復や構音異常を示していることが多かった（例；サシ カカルル，ソフトコクリーム). そして発声時間は D A FがNAFの約 1.5 倍であり, 各単語の間で発音に難易 差はみられなかった。

(2) 失語症柇考：軽症例では正常者と同じくDAFで は語尾の反復が扣もな変化であるが，中等度になると A Fでも錯語があらわれ，DAFでそれがさらにひどく なる傾向がみられた（例；さしかかるいサカジクシシ).

まとめ：全般的にみると正常者の D A F 効果は，1)声 が大きくなる，2)50音はウ，エ列で反復しやすい，3)復 唱は語尾で反復しやすい，4)D A F 効果の顕著な人とそ らでない人の 2 群に分かれる.

失語症患者の D A F 効果は1)声の変化がない，2)健忘 失語は正常者に近い反応を示す, 3)伝導失語は錯語が顕 著になる，4)重症になるとD A F 効果はなくなる.

質 問: 帝京大・田中美郷 D A F を失語に用いた目 的は,また, 失語の程度によってD A F 効果が異なるの は，どのよらなメカニズムによると考えて扣られるか.

応答: 東北大・永淵正昭 D A F を失語症に応用す る目的はこれによって言語障㕩のメカニズムが検討で きるかどらかにある。

重度の失語症はD A F 効果がない.これはフィードバ ック音声を単なる雑音(?)として聞いているためである うし，また発語中枢に重度の障害があれば，聴覚フィ一 ドバックで干渉されるまでもなく, 発語困難になるため であろらと考えている.

質 問 : 金沢大・鈴木重忠 聴覚過程の障害ともいわ れる伝導失語に拈いても, D A F 効果が大であった理由 をどら考えるか.

応答 : 東北大・永淵正昭 伝導失語は普通の状態で も言語㙨能が不安定である. それで D A F を負荷する と, 聴覚的な言語の干渉が加わって発語が, さらに不安 定になるのであろらと考える. 


\section{7. 失語症の呼称成績とヒント正答}

\section{金沢大学耳鼻咽喉科 能登谷晶子, 鈴木 重忠, 中島美喜子}

はじめに : 喚語困難を主症状とした失語症 4 例の呼称 に扎ける成績の変動と，聴覚的な語頭音によるヒント正 答の意義を検討したので報告する.

対 象:発症より 3 力月以上経過した C VA の患者 で, 初回の 100 語呼称テストで正答率が $40 〜 70 \%$ 範用 にあった 4 名を対象とした。

症例 1 は53歳男子で発症より 1 年経過, 症例 2 は 45 歳 男子で発症より 1 年 8 力月経過, 症例 3 は55歳男子で発 症より 8 力月経過, 症例 4 は 44 歳男子で発症より 3 力月 経過している. 4 例とも右利きで症例 $1,2,4$ は右片、 とを伴っている. 4 例とも S L T A (標準失語症検查) の結果で, 理解面より表出面の障害が重く, 喚語困難が 主症状の 1 つであった.

方 法 : 未訓練の 50〜87枚の絵カードの呼称成績を 1 $\sim 2$ 週間隔に計 5 回集計した. 正答, ヒント正答, 䛊答 の判定はS L T A の基準に従い，各症例の各回に扣ける 成績を検查単語別に正答，ヒント正答，㶽答にわけて検 討した。

\section{結果および考察 :}

(1)呼称成績 : 初回の成績は症例 1 で $62 \%$ ，症例 2 で49 $\%$, 症例 3 で54\%, 症例 4 で68\%であった. 5 回目には, おの沶の67，66，90，98\%となった．初回と 5 回目の成 績の差によって, 改善が30\%以上のものA群（症例 3 ， 4 )改善が $20 \%$ 以内のものB群（症例 2 ), 改善が $10 \%$ 以 内のものC群（症例 1）の3つに分けて見た.

また，どの症例でも呼称可能な語には一貫性のあるも のと変動するものに分けられた．先のA，B，C群別に 呼称成績の内訳をみると，ヒント正答であった語が次の 検査で正答となる率は, 呼称成績の改善が少なかった C 群では変動が大きく認められたが，A，B群では比較的 少なかった。 また，正答した語が次回の検査でも正答と なる率（正答の一貫性）は，呼称の改善が少なかったB， C群がA群に比し低い傾向にあった．正答した語が次の 検査で正答できなかった率をみると， B，C群はA群よ り高い傾向を示した.

(2) ヒント正答率 : 初回でヒントを与えた率は, 症例 1 が $38 \%$, 症例 2 が51\%, 症例 3 が $46 \%$, 症例 4 が $32 \%$ であ った。これらのうち，ヒントによって正答が得られた率
(ヒント正答率) は，おのおの $49,77,70,63 \%$ となっ た. A， B，C群別に初回から 5 回までのヒント正答率 をみると, C 群では変動が大きく, 初回のヒント正答率 も低かったが，A・B群では上昇する傾向にあった。 ま た，B群に比しA群でヒント正答率の向上が大きい傾向 が認められた。

以上のように, 呼称成績に著しい改善が認められた $\mathrm{A}$ 群では, 正答語の一貫性および初回のヒント正答率が高 く、また,ヒント正答率が上昇傾向を示した，B群では, 初回のヒント正答率は高かったが，ヒント正答率の向上 はA群よりも低かった. 呼称成績の改善が最も少ないC 群では, 正答語の一貫性が低く, 初回のヒント正答率も $\mathrm{A} \cdot \mathrm{B}$ 群に比し低く, 各回のヒント正答率の変動が大き かった.

以上のことから，呼称成績における正答語の一貫性 と, ヒント正答率は子後判定の因子として意義があると 示唆された.

まとめ : (1)呼称可能な語には一貫性のあるものと変動 するものが認められた。

(2) ヒント正答率が上昇するものと変動するものが認め られた。

(3)呼称成績の改善が著しいものは, 正答語の一貫性が 高く, ヒント正答率の向上を示した.

(4)呼称成績の改善が不良なものは, 正答語の一貫性が 低く, ヒント正答率の変動が著しかった.

(5)呼称成績の予後の因子として, 正答語の一貫性およ びヒント正答率が関与することが示唆された.

質 問：伊豆遁信病院・手束邦洋 対象患者は構音の 非流暢性を持っていたかどうか．その有無とヒント正答 率との関連はどらか.

応答：金沢大・能登谷晶子 subjects はいわゆる Broca 領域損傷群が多かったので， speech は非流暢で あったと思われる. また例数が少ないので，現在のとこ ろ流暢性との関連は, わからない.

質 問 : 横浜国立大・笹沼澄子 その他の cue (たと えば同意語，文脈など）を与える訓練を試みられたか。 その結果はどらか.

応 答 : 金沢大・能登谷晶子 1 例についてのみ他の 
ヒントも与えてみたが initial cue の場合と差がなかっ た。

\section{8. 失語症者における疑問文の運用}

\section{国立聴力言語障害センター 藤田 郁代}

コミュニケーション関係の成立や, 言語学習に重要な 役割を果たす文である疑問文を取りあげ，重度ブローカ 失語症者に再獲得訓練を行った. その結果, 疑問文の発 話, 聴覚的理解に関与する要因と再獲得の段階が明らか となったので報告する。

訓練した疑問文は yes-no 疑問文と「誰, 何, どこ」 の疑問詞を含むwh-疑問文である.これらの文の再獲得 過程は次の 3 点から分析する. (1)yes-no 疑問文と wh疑問文は質問の前提と焦点が異なっているが，このよう な構造上の差異が再獲得に及ぼす影響をみる。(2)yes-no 疑問文には, 質問の焦点が単一の語にあてられている文 (それは柿か) と, 文中の語にあてられている文（柿を 見ているか）があるが，どちらの再獲得が容易かをみる. (3)wh-疑問文では，質問の焦点の指示の仕方に次の 3 種 があるが，このような指示の仕方による再獲得の差異を みる. (1)疑問詞の意味素性のほかに, 文中の名詞と動詞 の意味関係 (格) が質問の焦点を指示する(「誰が柿を 見ているか」などの非省略文), (2)疑問詞の意味素性のほ かに助詞が示す格が焦点を指示する（「誰が見るか，何 を見るか」などの省略文). (3)疑問詞の意味素性だけが 焦点を指示する (「それは誰か，何か」).

症 例：音声, 文字ともに言語の理解と産生が重度に 障害されたブローカ失語症者. 41歳, 男.

訓練期間 S52.2〜 S 53.7. 100セッション. 訓練方 法, 絵に描いた語や文に関して情報を求める形で行っ た. 疑問文の訓練は29個の語と簡単な叙述文の発話, 聴 覚的理解が可能となった時点で開始した.

結果：(1)yes-no 疑問文と wh-疑問文の再獲得の差異 については，すべての yes-no 疑問文は wh-疑問文より 容易に聴いて理解できるようになった。(2)yes-no 疑問 文のうちでは，単一の語に質問の焦点がある文は，文中 の語に焦点がある文より, 容易に聴いて理解できるよう になった．(3)wh-疑問文における質問の焦点の指示の仕 方による再獲得の差異については, 次のような獲得のプ ロセスがみられた。まず，「誰,何」を対にして「誰が見 るか，何を見るか」のように，疑問詞と助詞が質問の焦 点を指示する文を訓練したが，これらの文の発話，聴覚 的理解が可能となるにはさきに「誰が柿を見るか」のよ
らに，疑問詞のほかに名詞と動詞との意味関係が焦点を 指示する文の発話, 聴覚的理解が可能になることが必要 であった，つまり，前文は後文が獲得された後に獲得さ れた. 次に，これらに「どこ」を加えて，「誰が見るか， 何を見るか，どこで見るか」を導入したところ，確実と なっていた「誰，何」も不確実となった。これは今ま で，「誰，何」が〔士human〕という意味素性でなく， 「誰」は行為者格，「何」は対象格という格概念と対応 させて把握されていることを疑わせた．そこで「誰，何」 のいずれもが行為者格や対象格の語を指示しらる「子供 が誰を（何を）見るか」や「誰が（何が）魚を見るか」 の文や，「どこ」が目標格や対象格の語を指示する「ど こに置くか」や「子供がどこを見ているか」などの文を 訓練した.すると, これらの文の発話, 聴覚的理解が可 能となるにしたがって，「誰が(何を，どこで)見るか」 などの聴覚的理解が確実となった，同時に，疑問詞だけ が質問の焦点を指示する「それは誰（何，どこ）か」の 文の発話, 聴覚的理解も確実となった.

これらの結果から, 次のような疑問文の再獲得の段階 が導ける. (1)yes-no 疑問文のらち, 質問の焦点が単一 の語にある文の運用が可能となる（2)yes-no 疑問文の らち，質問の焦点が文中の語にある文の運用が可能とな る. (3)wh- 疑問文のうら, 質問の焦点が疑問詞の意味素 性のほかに，名詞と動詞の意味関係によって指示される 文の運用が可能となる．(4)wh-疑問文のらち質問の焦点 が疑問詞の意味素性だけで指示される文の運用が可能と なる.これらの各段階に達するには，次のことが可能に なることが必要である. (1)へは語の理解, (2)へは文中の 語の抽出と理解，(3)へは文中の動詞が取りらる格の抽出 と理解，(4)へは格と疑問詞の意味素性が分離され，疑問 詞自体の意味素性で統合できることである.

質 問：川崎医大・森 寿子 (1)幼児のばあい，疑問 文はある程度高度な言語レベルに達していないと, 理解 および表現はできない。本症例のような重度な言語障害 のあるものに対して，疑問文の指導を選択した意義はど こにあるか. また，呼称指導などと疑問文の指導はどち らが先行すべきでどちらが有効だと考えるか. (2)この指 導を行った後に, 言語症状はどの程度, どのように改善 
・変化したか，また，その時の知能の状態はどうか，

応 答: 国立聴言センター：藤田郁代 (1) どの疑問文 を獲得させるかにより異なるが，段階(1)では語の理解， (2)，(3) では文中の名詞間汇可逆性のない文の理解，(4)で は名詞間に可逆性のある文の一部の理解が獲得されてい
る時期に開始することが妥当と考兄られる. (2)格概念と いう抽象的言語, 単位をあらわす助詞の発話, 理解力が 特に改善した。 また, 他の言語記号操作力（文字, 語な どに関して）も全体的に level up した. 知能は, WA I S 動作性 80 程度の低下が認められた。

\section{9. 失語症における漢字・仮名の障害について}

—文字の理解——

伊豆菲山温泉病院 望月理恵子, 柏木 敏宏, 柏木あさ子, 高地 武夫 佐野 洋子, 長谷川恒雄
失語症患者に和ける漢字と仮名の障害は，それぞれの 言語学的特徵の差異が，大脳の異なる機能に結びついて いるといら点で, 古くより注目されてきた。漢字は意味 と形の処理機構を, 仮名は音と形の処理機構を, それぞ れ異なる機構を直接ないしは問接に経るといら仮説が支 持されているように思われる，われわれは，この仮説 が，これまで実験されていない様式においても，妥当で あるか否かを調べる目的で, 次のよらな实験を行った。

方 法: 単語を聴かせ， 6 つの選択肢を提示し, 正し い文字を指差させた，単語は, 日常生活で比較的頻度が 高いと思われる8 語で, 漢字と仮名の検査に共通に用い た.

漢字の検査の選択肢は，〔音と形〕の似ているもの， [意味]の似ているもの，[意味と形〕の似ているもの， [形】の似ているもの，【無関係〕なもの，〔正答〕の 6つである．類似の基準は，次のように定義した。〔音〕 の類似とは, 同音または 2 音素以内の違い, 〔意味〕の 類似は，同義語または関連語，〔形〕の類似とは熟語の らちの 1 文字の類似とした。

仮名の検査の選択肢は[音と形]の似ているもの，

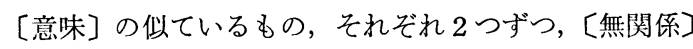
なもの，〔正答〕の 6 つである. 音の類似は，4 拍の熟 語については音素以内の違い， 5 拍の熟語については 3 音素以内の違いと定義した.

選択肢は，それぞれの検査において，各項目ごとに， ランダムに配置した。制限時間は, 単語を聴かせてから 30秒で，単語は何回聴かせてもよいこととした。

対象者: Weisenburg \& McBride による分類で, Exp. Rcp. 型 4 名, Pred. Exp. 型26名, Pred. Rcp. 型 21 名, Amn. 6 名, 計 57 名である. 平均年齢51歳. 平均 教育年数 12 年. 原因疾患は, C V A 54名, 脳腫瘍 1 名,
外傷 1 名, 脳炎 1 名である. 著しい聴覚障害, 視覚障 害, および知的低下のある者は除外した.

結果および考察：(1)漢字の正答率は, 全体では $86 \%$ で あった. タイプ別にみると, Exp. Rcp. 47\%, Pred.

Exp. 91\%, Pred. Rcp. 88\%, Amn. 90\%であった. 仮 名の正答率は漢字より低く, 全体の正答率は $71 \%$ であっ た.タイプ別では, Exp. Rcp. 16\%, Pred. Exp. 71\%,

Pred. Rcp. 79\%, Amn. 83\%であった.

(2)漢字・仮名の䛊り方に差がみられた. 漢字では, [意味と形】［意味】，〔形]の誤りが，誤り全体の $97 \%$ を占めている。【仮名〕では，〔音と形〕の誤りが，誤 り全体の $82 \%$ を占めている. この傾向は, 失語症のタイ プ別にみても差がみられなかった。

(3)得点によって 2 群に分け, 誤り方を比較した. 漢字 においては, 得点の低い方においても, 高い方において も，〔意味と形】［意味】，〔形〕に多く誤る傾向がみら れた．仮名に执いては，2群とも〔音と形】に多く誤る 傾向がみられた.ささに, 漢字では, 得点の低い方に比 べ，得点の高い方で，〔形〕の似ているものへ詋る傾向 がみられた。

以上より，単語を聴き，選択肢の中から正しい文字を 指差す過程は，漢字と仮名で異なっていると思われる。 漢字に招いて，〔意味〕と〔形】に関する誤りが，仮名 に打いては, [音]と[形】の誤りが多いという結果は, それぞれの文字体系が，意味と形の処理 機 構，あるい は, 音と形の処理機構に強く関係しているといえる.こ れは従来の仮説を確認するものである.

また得点別に誤り方を分析した時に，漢字の得点の高 いほうでは, 得点の低い汪らに比べ, 〔形】の誤りが多 くなっていた．この傾向は，このテストを正常者に施行 した場合の䛊りの傾向と一致している.ゆえに, 得点の 
高いほうの誤り方は，正常者に近い傾向を示すといえ る。

質 問：伊豆逓信病院・勝山和長 仮名は音に密接と いらが，音も本質的には意味として考えられるのではな いか. またこう捕えると，漢字も仮名も当然意味に結び つくが，漢字のほうはその結びつく意味が細かく分化さ れていて，漠然としたものは無論，さまざまな経路にお
いて言語として指定された意味にも結びつき得るが，仮 名の場合このようなことは起こり得ず，聴覚系での単な る音現象にしか結びつかないのではないかと思われる が，この点に関してどら思われるか.

応 答: 伊豆菲山温泉病院・望月理惠子 仮名単語 は, 音, 意味, 形, に結びつくが, 仮名 1 文字が, 意味 に結びつくとは思えない。

90. 伝導失語症の発現機序に関する検討

- 1 症例を中心に一

七沢老人リハビリテーション病院 員見 芳房, 竹内 愛子

伝導失語症者は復唱の困難, 発話における字性錯語, 1 つ以上の語音を反復修正しながら意困した正しい語を いおうとする phonemic approaches を特徵的に示す. 本稿は 1 人の伝導失語症者 [元小学校長右利き 74 歳男, 脳硬塞発症 1 年後から 3 力月間言語訓練, 四肢運動能力 正常]の言語症状を中心に, 上記の伝導失語症状を二次 的なものと考えて，それらの基底にある言語機構上のよ り根本的な障害を推定しようと試みたものである。

需語症状の特徴 : 以下に記す症状は問題をはっきりさ せるために単語レベル（名詞）に限られる.(1)復唱：一 音節語をも含めた, 語が聴覚的に理解されているつまり 漢字で正しく書き取れたのに復唱に失敗した（例；〔歯〕 ほか，ほかれつ，〔北〕すた，す，た，(2)呼称：発話は 流暢だが，その多くを誤った. 新造語が多く，一様に phonemic approaches を示した. 初頭音や正しい語を 聞かせても，部分的に修正されるのみで多くが字性錯語 となった（例；〔本]でないね…でないね‥よみなが...

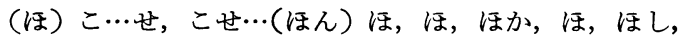
ほ, ほーと, ほーと,（）はcue). (3)書字と音読：こ の 2 つの課題では, 日本語に固有な文字体系つまり漢字 と仮名の間で特徵的な違いを示した. 書字では，漢字の ほうがはるかに容易で，仮名は錯書が著しかった（仮名 の例；〔犬〕いね，【机〕つく）、さらに，仮名を漢字に 書き換えるほうがその逆より容易であった．対称的に音 読では，仮名は流ちょうで，検査 (高頻度語) では全く 䛊ることがなかった. 漢字では錯読を示した（漢字の例

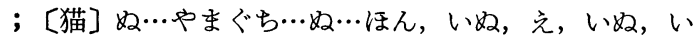
ぬ, くち, ない...いら, いぬ, [机]つ, だめだ, つつ ‥つ<).

本症例の言語機構上の障害の推定 : 復唱以外の呼称,
書字および音読について検討してみると，困 難な課 題 (呼称，仮名の書字，漢字の音䛃）は，いずれも音表現 としての語を自発的に喚起する必要性の高い課題である と考光られる. それに対して，表音的性格の強い仮名の 音読は良好で，むしろ実際の訓練では喚語のための視覚 的な手がかりとして利用された．Dubois（1964）は，伝 導失語症を口頭表出過程における第一次分節，つまり形 態素の選択と結合の障害を指摘した．本症例の言語症状 の紹介において，その対象とした名詞が形態素に相当す ると考えても良いと思われる。したがって，本症例の語 を自発的に喚起する必要性の高い課題での困難は，Dubois らの唱える，とりわけ形態素の選択の困難つまり口 頭表出過程における第一次分節の障害であることを示唆 している.

復唱について：伝導失語症を口頭表出過程の障害と又 なすと，この障害が最も severe にあらわれるのは呼称 課題においてであり，復唱に打ける聴覚刺激は，むしろ 正しい語の表出のための手がかり的な役割を果たす場合 もあると考えられる，その点について，他の伝導失語症 3 例の呼称と復唱の成績が同じ語（高頻度語）の間で比 較された．結果は 3 例とも復唱のほうが良好で，呼称で さる語はほとんど復唱もできていた（症例 S.N. ; 問題 60 語, 呼称正答 25 語, 復唱正答 43 語, 呼称, 復唱のこれ らの正答語の中でそれら両方の課題で正答した語23語. 以下症例 To. $\mathrm{Ta} ; 57$ 語中 41 語, 54語, 41 語, 症例 $\mathrm{Ta}$. Ta. ; 76語中59語, 68語, 56語). 次に䛊答の中の錯語が 分類された. 症例 S.N. は語頭の誤り(〔新聞】せんぶ ん）が, 症例 To. Ta. と Ta. Ta. は語尾の誤り（〔ステ レオ]ステルス) が, 呼称, 復唱いずれにおいても最も 多く，その間に錯語のあらわれ方の違いを認めることが 
できなかった.

以上の結果は伝導失語症の復唱の困難が, 呼称と同じ つまり口頭表出過程の障害によるものであることを示唆 している.なお，言語症状を記した症例は新造語が多か った，伝導失語症の錯語のあらわれ方は重症度や損傷の 範囲などで異なると思われる。

質 問：金沢大・鈴木重忠 古典論での伝導失語との 違いをどう考えるか.
忘答 : 七沢リハビリテーション病院・苚見芳房 伝 導失語症は, 聴覚的理解は良好なのに復唱が困難, 発話 は流ちょらだが，錯語に覆われているなどの特徵があ る. 本ケースは, いずれも, 四肢運動マヒはなく, 上記 の特徴を示し，伝導失語症と診断された．それは古典論 にいら症状に合致する. それを前提に，検討したもので ある。

\title{
91. 伝導失語症例の音韻変化
}

\author{
東京都養育院付属病院 物井 寿子, 福迫 陽子 \\ 横浜国立大学, 東京都老人総合研究所 笹沼 澄子
}

伝導失語では，良好な聴覚的理解力と，流ちょうで灵 用的な発話能力があるにもかかわらず，呼称，復唱，情 景画の説明など，構成された場面での発話に拈いて顕著 な音韻変化を示す，ブローカ失語においてもまた，音韻 変化は特徵的な所見の 1 つである. 今回われわれは，両 群の音韻変化を比較することにより，その特徽を明らか にすることを試みた。

対象は典型的な伝導失語およびブロ一カ失語各 3 例で ある。伝導失語の 1 例を除き，C八スキャンの結果が得 られており，それぞれ特有の損傷部位が認められた。す なわち病巣は, 伝導失語ではシルビウス溝のやや上方に あり,ブローカ失語では前頭葉から頭頂葉にわたってい た。

発話サンプルは，呼称と単語の復唱（以下それぞれ自 発, 復唱とする) から得た. 分析の対象とした音韻変化 の数は, 伝導失語では自発 191 278 個, 復唱 $137 \sim 279$ 個, ブローカ失語では順に76〜100個, 復唱71〜114個で あった。

まず，音韻変化が，子音，母音，その他（長音, 揆音, 促音) のどこに生じるかをみた，伝導失語では，自発， 復唱とも, 子音と母音の両方に同程度, 寸なわち $5: 5$ から 6:4の割合で音韻変化がみとめられた. 一方，ブ ローカ失語では, この比は $9: 1$ と, 大部分が子音であ り，母音では音韻変化が少ないことが特徵的であった。 なお, 両群とも, 自発と復唱では大きな差は認められな かった.

次に, 子音の誤り方を, 置き換光, 転置, 付加, 省略に わけて調べた，置き換えとは目的の単語に含まれていな い音韻への変化をさし, 転置とは目的の単語に含まれる 音韻が不適切な順に発語されたものをさす. 伝澊失語で
は, 置き換えと転置の割合が約半々であるのに対しブロ 一力失語では置き换えが $7 〜 8$ 割を占めており, 子音の 哭り方についても両群の間には著明な違いがあることが わかった.さらに, 伝導失語の母音について同様に調べた 結果, 子音の場合と同じく転置が大きな割合で生じた.

最後に，誤り音と正しい音のちがいを，弁別素性を用 いて分析した. その結果, 置き換えについては, 両群と も弁別素性が 1 異なる音への変化が多い点で共通して いた. しかし，ブローカ失語ではこの傾向がさらに強く あらわれていた。 また，翼り音の内容をみると，伝導失 語では一定の傾向がないのに対し，ブロ一カ失語では, 構音動作のより複雑な音の誤りが多いといら傾向が認め られた．このことは, 構音動作が容易な母音が保たれて いることと併せて, ブローカ失語では構音運動の障害, すなわち運動の企画の障害による誤りがあることを示し ていると考えられた.

同じく弁別素性を用いて，伝導失語に括ける置き換え と転置とを比較したところ，転置では置き换えの場合と 異なり, 弁別素性が 1 つ異なる音への変化は少なく，ピ 一クは 4 〜のところに認められた. なお，この分布 は，あらゆる子音を組み合わせた場合に起こるランダム な䛊りの分布とほぼ一致した。この結果は，置き換えで は，目的とする音韻の選択に際して何らかの規則が働 き，より近い音韻が選択されたのに対し，転置では，単 語を構成する音韻の順序を誤ったために生じたと考えら れる.なお，母音についても同様の結果を得た.

以上ををとめると，伝導失語では，子音と母音の両方 に呮りが生じ，䛊り方は置き換えと転置がほぼ半々であ ったのに対し，ブローカ失語での誤りは主として子音に 生じ，誤り方は置き換えが圧倒的多数を占めた．このこ 
とから, 雨群とも音韻論的レベルの障害としての音の選 択の障害が疑われるが，伝導失語ではこれに加えて音の 順序化に打もな障害があるのが特徽であり, 一方, ブロ 一カ失語では構音運動の企画の障害が認められることが 特徵であると考えられた。

質 問：金沢大・能登谷晶子 伝導失語では復唱の 際, 単語では easy な場合が多いと思うが, 今回, 単語 を用いて結果を出した理由は.

応答 : 養育院付属病院・物井寿子 今回は, 自発と 復唱を比較することが目的であったので, 有意味語で行 った.

質 問：伊豆菲山温泉病院・柏木敏宏 ブローカ失語 の音韻の誤りを, 構音の運動企画の障害とした根拠を教 えて欲しい.

忍 答：養育院付属病院・物井寿子 ブローカ失語で は，音韻論的レベルの障害に加えて運動企画の障害が特 徵であるとのべたが，後者の根拠は，母音で誤りが少な いこと, 置き換えの内容をみると, 構音運動のより複雑 な音に誤りがみられると，である。

質 問：七沢リハビリテーション病院・員見芳房 伝
導失語症者の示す錯語のあらわれ方は，重症度や損傷の 広がりなどによって異なると考えるが，その点について 考えを打聞きしたい。

応 答：善育院付属病院・物井寿子 員見氏の例では 転置が少なかったとのことであるが，分析方法に差があ る可能性がある.なお，1例について，経過をみたが， 音韻変化の内容に差はなかった，ただし，音韻変化の起 こる頻度, 修正の可否等については変化がみられた.

質 問：金沢大・森 源三郎 Blumstein, S.E.(1973) の研究を日本人 (語) 失語症患者について, 発展された わけであるが，音韻分析データからみて，日米比較で固 有言語に拘束されない，独立した音韻変化が認められる か.

応 答：戠育院付属病院・物井寿子 われわれの結果 は, Blumstein のそれとは違っているが，これは分析方 法の違いによると考えられる.しかしながら，この点を 考慮して両者を比較検討すると，一部同様の知見も認め られる.したがって，この点では日本語と英語では同じ であるといえよう。

\section{2. 発語失行 4 症例の誤りの分析と言語訓練経過}

\section{金沢大学耳鼻咽喉科 中島美喜子, 鈴木 重忠, 能登谷晶子}

はじめに：脳血管障害に由来する発語 失 行 (apraxia of speech） 4 症例の復唱に打ける誤りの分析と，3症 例の言語訓練の効果について検討したので報告する.

症 例：症例 1 は男性で44歳. 〈も膜下出血, 検査時 発症後 2 年経過しており重度の運動失語である. 症例 2 は男性で52歳. 脳血栓, 検査時発症後 4 力月経過してお り, 言語症状は軽度の運動失語に軽度の dysarthria を 伴っている. 症例 3 は男性で 42 歳. 左脳内血腫右マヒを 伴っている．検査時発症後 5 力月経過しており，言語症 状は中度運動失語である. 症例 4 は女性で33歳. くも膜 下出血, 右マヒを伴っている. 検查時発症後 4 力月経過 しており，言語症状は軽度の運動失語である. 4 例とも 右利であった。

復唱検査; $\mathrm{V}$ (vowel) -5 組, C (consonant) - 58組, V C V - 290組, C V C V-1, 225組の 1 音節63組と 2 音 節 1,515 組, 合計 1,578 組を復唱させ, 䛊りの傾向を求め た.

復唱検査結果 ; 誤り率は症例 1 と 2 は V, C Vの単音 節で，誤りはほとんどみられなかったが，V C V , C V
$\mathrm{CV}$ の 2 音節になると誤り率が $30 \%$ に増えた。症例 3 は 検査音 5 個のVのらち 2 個の誤りが，CVで55\%の䛊り が，VCV，CVCVでは 55〜 60\% の誤りがみられ， 1 音節と 2 音節の誤り率はほぼ等しかった. 症例 4 はV で1個，CVで $30 \% ， \mathrm{VCV}, \mathrm{CVCV}$ とも $20 \%$ の誤 りであり，1音節より 2 音節での誤り率が低くなってい る. 誤り方は, 4 症例とも子音の同じ manner の間での 置換が大部分を占めていた，症例 $3 ， 4$ のVの䛊りはす ベて子音の付加であり, C V, および 2 音節での䛊りに は構音点が同じものの間での䛊りや, 有声音の無声化な ぞもあった。置換された音は，症例 2 が dysarthria を 伴っているためか，/s /音が圧倒的に多かった他は/p/, $/ \mathrm{t} /, / \mathrm{h} /$, で多かった. 後続母音による影響は, 症例 1 と 4 が $\mathrm{C}_{1} \mathrm{~V}_{1} \mathrm{C}_{2} \mathrm{~V}_{2}$ の $\mathrm{V}_{1}$ が/i/のとき䛊りやすい傾向を示 した.

言語訓練；症例 $1 ， 2 ， 3$ に対して行った. 1 音節よ り 2 音節に誤りが多かった病例 $1 ， 2$ に対しては，1 音 節で誤った音を確立した後に，無意味 2 音節を使用して 誤りやすい音との交互練習を行った， 1 音節と 2 音節の 
誤り率がほぼ同じであった症例 3 に対しては，1音節の 構音の確立を目標とした. 方法は, 復唱や音読が困難で あったので，口型文字を cue として訓練をした。

訓練結果; 訓練効果の判定として 100 語の呼称成績を 用いた. 絵をみて prompt に正答の得られたものを 3 点, よどみや自己修正がみられるが正答のものを 2 点, 音韻変化があるものを 1 点, 呼称できなかったものを 0 点とし, 計 300 点満点の得点とした. 各症例の訓練前後 の得点は, 202 点 $\rightarrow 257$ 点, 227 点 $\rightarrow 279$ 点, 84 点 $\rightarrow 157$ 点 と上昇した.

まとめ：従来 apraxia of speech の音韻変化は一貫性 がないとされてきたが, 症例により誤りやすい音や，後 続母音による難易度の違いや, 置換の内容も同じmanner で棈音点が移動するもの, 同じ構音点で manner が変化
するもの，有声音の無声化などの傾问がみられた。 た，症例 $1 ， 2$ のように語音の産出は可能であるが，語 音を組み合わせることが困難なタイプと，症例 $3 ， 4$ の ように倜々の語宵の構音とのものが困難なタイプに分け られた、また，タイプと誤りやすい音や䛊り方の内容と

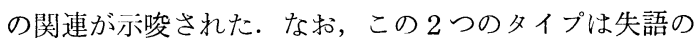
重症度とは直接関連がないようであった。

言語訓練として，復唱検査により誤りの規則性を調 ベ，語音の組み合わせが困難なタイプには誤りやすい音 との交互練習を, 個々の語音の構音そのものが困難なタ イプには，口型文字などの視覚的な cue を用いて語音を 確立する練習を行えば，ある程度効果が期待できること がわかった。

\title{
93. 発語失行症患者の Voice Onset Time
}

\author{
東京都老人総合研究所 伊藤 元信, 辰巳 格, 小林 洋 \\ 横浜国立大学・東京都老人総合研究所 笹沼 澄子
}

目 的: われわれは, 発語運動の企画の障害とされる 発語失行症の障害像を明らかにする目的で, 一連の観察 を行ってきている. 構音器官の運動観測のこれまでの結 果は, 発語失行症患者の障害の一側面として, 複数の樍 音器官の間の時間的協調の乱れが存在することを示して いる(伊藤ら，1978）. 今回は，上記の知見をらま光， 喉頭とその上部の構音器官の運動のタイミング調節の状 況を把握する目的で, 発語失行症患者の発話の voice onset time (VOT) を測定した.

方 法: 被験者は, 発語失行症状を主症状とする脳損 傷患者 4 名（40６6歳）および, 対照群としての若年正 常者 4 名（25３2歳）ならびに老年正常者 5 名（66〜 72 歳) である. 発語失行症患者 4 名のらち 2 名は軽度の失 語症を合併している（最近の Schuell の分類, Jenkins ら，1975，に従えば,非流ちょうな構音を伴ら失語群に該 当する). 検査材料は, $/ \mathrm{de} /, / \mathrm{te} /, / \mathrm{ge} /, / \mathrm{ke} /$ の 4 音 節で，それぞれの音節を平仮名表記し，1 音節ずつ音読 させた.なお，読み䛊った場合には読み直させた，発話 順序はランダムにし, 各音節につき 25 個ずつ, 計 100 個 の発話サンプルを各被験者から得た. 各発話サンプルに 関して, 広帯域サウンドスペクトログラムを得, VOT を測定した. 測定は, Lisker \& Abramson (1964) の方 法に従った. すなわち, サウンドスペクトログラム上で 観察される破裂の時点から, 声帯振動開始の時点までの
時間間隔を测定した。被験者ごと，音節ごとにVOT の 分布図を求め，構音点を共有する有声と無声子音からな る音節の対である/de/と/te/, /ge/と/ke/の VOT 分布 を比較した.

結果と考察：正常者（若年，老年とも）の発話では， /de/と/te/の VOT は明らかに異なり, 老年者の 1 部の 発話を除いて，両者のVOT 分布には重なりがみられな かった. $/ \mathrm{ge} /$ と/ $\mathrm{ke} /$ とつてもほぼ同様の結果が得られ た.これらの結果は, 正常者においては, 声道の開放と 声帯振動の開始のタイミングに関して, 有声子音と無声 子音との間で, 明確な区別がなされていることを意味し ていると思われる. 一方, 発語失行症患者は特異な VOT 分布を示した.すなわち，4名中 3 名に和いて, 有声と 無声子音の VOT 分布に著しい重なりが認められた.な 拈, このうらの 2 名では, 正常者の/de/において観察さ れた voicing lead, すなわち有声子音/d/発話時に声帯 振動の開始が，声道の開放に先行して生ずる現象がほと んど浔められなかった.ささらにこのうちの1名は, /ke/において異常に長い voicing lag（すなわち, 子音 $/ \mathrm{k} /$ のための声道の開放から後続する母音/e/のための声 帯振動の開始までの時間間隔が, 正常者のそれに比べて 著しく長い) を示した。 また，有声と無声子音の VOT 分布に著しい重なりを示さなかった被験者 1 名において も, /de/の発話に打いて, 異常に長い voicing lead が 
認められた. これらの結果は, 対象とした発語失行症患 者では, 声道の開放と声带振動の開始のタイミング調節 に破たんが生じていることを示すものと考えられる。今

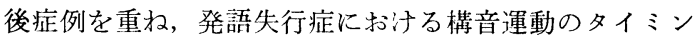
グ調節の障害の状態を明らかにして行きたい。

\section{文 献}

1）伊藤元信, 笹沼澄子, 牛島達次郎, 広瀬 肇, 吉岡博 英 : 発語失行症における発話時の構音器官の動態— ファイバースュープ执よ゙X線マイクロビームシステ ムによる観測——音声言語医学, $19: 285$-296, 1978.

2) Lisker, L., \& Abramson, A.S.: A Cross-Language Study of Voicing in Initial Stops: Acoustical Measurements. Words, 20 : 384-422, 1964.

3) Jenkins, J.J., Jiménez-Pabón, E., Shaw, R.E., \& Sefer, J. W. : Schuell's Aphasia in Adults : Diagnosis, Prognosis, and Treatment. Harper and Row, New York, 1975.

質 問: 帝京大・田中美郎「発語失行」,「構音失行」 といら用語が使われているが，これらの用語に違いはあ るのか, CTスキャンの出現により, 病巣が簡単に確認 できるようになってから，特に発語失行の定義はあいま
いなものになっているように思われるが.

応 答: 東京都老人総合研究所・伊藤元信 演者らは Darley らのいう apraxia of speech ないし verbal apraxia の訳語としての「発語失行 (症)」と「構音失行」 とを，同意語として用いている．ただし，Darley らの 記述による発語失行症の臨床症状の中には, 彼らの定義 にあてはまらない症状（発語運動の企画の障害としては 説明困難な症状）も含まれており，このことが，用語な いし概念に関する混乱を招いていることを付け加える.

質 問：東大・桐谷 滋 発語失行症患者で, 無声音 でVOTが小になるが，ばらつきは小さい人と，そらで ない人とがいるが，特殊な要因があるのか.

応答：東京都老人総合研究所・伊藤元信 ご指摘の 通りであるが，その理由については明らかでない.なお， 共通のパタンを示した症例 1 と症例 2 は比較的純粋な発 語失行症例であり, 症例 3 と症例 4 は発語失行症状に加 えて軽度の失語症を合併している.ところで, 最近の Freeman らの発語失行症例 ( 1 例) のVOT測定 結 果 は, われわれの症例 1 と症例 2 の結果と良く似ている. Freeman らは，得られたVOT分布は，幼児の構音習 得時の初期のものと類似していることを指摘している.

\section{4. 構音失行に扮ける言語症状について}

伊豆菲山温泉病院 柏木 敏宏, 柏木あさ子, 高地 武夫, 望月理恵子, 佐野 洋子 長谷川恒雄

目 的：一般に構音失行を持つ患者は，失語症が合併 していることが多い，構音失行と失語症を併せ持つ症例 においては, 話しことばの障害の中から“構音の失行” すなわち構音の運動企画の障害によるものだけを，それ 以外の障害によるものから分離してとり出すことは困難 である. したがって構音失行を理解するには, 純粋に構 音失行のみの症状を呈する症例の研究が必要である. そ こでわれわれは失語症が軽微で, 比較的純粋に構音失行 のみを呈している患者を対象に，言語症状の分析を行っ た.

方 法 : 伊豆韮山温泉病院に入院した言語障害患者の 中から 5 名を対象とし, 入院時, 退院時の医学的検査所 見，言語面の検查所見および言語訓練の経過から得た資 料を分析した. 5 名の症例は, E. O. 氏（男） 71 歳 C V A， H. Ki. 氏 (男) 21歳脳腫瘍, H. Ko. 氏（女）42歳 C V A, T.M. 氏 (男) 50 歳脳腫瘍， S. T. 氏（男） 60
歳 C V A である. 5 名の選択条件，すなわち比較的純粋 に構音失行を呈しているとした条件は検査時に次のこと が満たされている場合とした. (1)失語症的な要素が少な いこと，すなわち話しことばの障害が著明であっても， 書きことばの障害は軽く, かなり複雑な内容を書いて表 現することが可能であり, 仮名の障害もほとんど認めら れない. 聴覚的および視覚的理解の障害も無いか, あっ ても軽度である. (2)oral apraxia 的な要素が少ないこ と, すなわち発声発語器官の運動の失行はないか, あっ たとしてもそれによっては話しことばの障害を説明でき ないと判断される程度の, ごく軽いものである. (3)dysarthria の要素が少ないこと, すなわち発声発語器官の 運動障害がないか，あったとしてもそれによっては，話 しことばの障害を説明できないと判断される程度の軽い ものである. (4)著しい知的低下, 聴覚障害, 視覚障害が 認められない。 


\section{結果および考察}

(1)構音の障害とプロソディーの障害について：まず各 患者の会話に扰ける構音の状態について簡単に述べる. E. O. 氏は音の歪みを主体とした静音で，言語音として はほとんど伝わらない状態であった. H. Ki. 氏は発語は 全くなく, 意志伝達は身振りや筆談で行っていた. H.Ko. 氏は文を用いた会話ができるが，子音の置換や省略が目 立った. T. M. 氏と S. T. 氏は複雑な内容の会話ができ るが，構音がたどたどしく，会話に時間を要し，聴き手 の注意の集中を必要とした. 以上全員に構音の問題がみ られたが，同時に prosody の問題も認められた. E. O. 氏と H. Ki. 氏は 1 音節の構音そのものが困難な場合 が多く, prosody の障害も強い.ただし H. Ki. 氏にお いては言語訓練に伴い構音可能になった音を組み合わせ て単語にする場合にも，2音節の結合すら滑らかでな く, 常に 1 音節ずつ区切るように構音した. T.M. 氏と S. T. 氏の場合はゆっくりと 1 音節ずつ区切るような話 し方であれば明瞭度は高い.しかし速度あるいは滑かさ を要求されると, 構音の障害が大きくなってくる. 構音 失行の構音の観察は, 常にプロソディーとの関係で捉え
ることが重要である.

(2) 構音の䛊り方について：明らかに付加や置換を示す 症例（H.Ko.氏）もみられたが, 歪みの著明な症例（E. O.氏）や構音不能が多い症例（H. Ki. 氏）もみられた. それぞれの䛊りの傾向は会話, 復唱, 音読などでほぼ一 貫していた.

(3)自動的発語と随意的発語における症状の解離が明ら かに認められた症例はなかった、構音およびプロソディ 一の障書のされ方は,ささざまな言語環境でほぼ一貫し た状態であったといえる。

(4)以上，比較的純粋に構音失行を呈している患者の症 状は, 構音の運動プログラミングの損傷がもたらす症状 として十分納得できるもので，一般にいわれる構音失行 の特徵は再吟味されるべきと考える.

态 答 : 伊豆菲山温泉病院・柏木敏宏 構音失行は発 語失行と同じ意味に用いている. ただ Darley の定義に 従らが，Darley らの矢際の使い方をきらって， verbal apraxia 構音失行を用いている（この応答に対応する質 問は93番に対するものと同一である). 